\title{
Determination of plutonium isotopes in waters and environmental solids: A review
}

Qiao, Jixin; Hou, Xiaolin; Miró, Manuel; Roos, Per

Published in:

Analytica Chimica Acta

Link to article, DOI:

10.1016/j.aca.2009.03.010

Publication date:

2009

Link back to DTU Orbit

Citation (APA):

Qiao, J., Hou, X., Miró, M., \& Roos, P. (2009). Determination of plutonium isotopes in waters and environmental solids: A review. Analytica Chimica Acta, 652(1-2), 66-84. https://doi.org/10.1016/j.aca.2009.03.010

\section{General rights}

Copyright and moral rights for the publications made accessible in the public portal are retained by the authors and/or other copyright owners and it is a condition of accessing publications that users recognise and abide by the legal requirements associated with these rights.

- Users may download and print one copy of any publication from the public portal for the purpose of private study or research.

- You may not further distribute the material or use it for any profit-making activity or commercial gain

- You may freely distribute the URL identifying the publication in the public portal

If you believe that this document breaches copyright please contact us providing details, and we will remove access to the work immediately and investigate your claim 


\title{
Determination of plutonium isotopes in waters and
}

\author{
environmental solids: A review
}

\author{
Jixin Qiao $^{\mathrm{a}}$, Xiaolin Hou ${ }^{\mathrm{a}^{*}}$, Manuel Mirób ${ }^{* *}$, Per Roos $^{\mathrm{a}}$ \\ ${ }^{a}$ Radiation Research Division, Risø National Laboratory for Sustainable Energy, Technical University of Denmark, DK-4000 \\ Roskilde, Denmark \\ ${ }^{\mathrm{b}}$ Department of Chemistry, Faculty of Sciences, University of the Balearic Islands, Carretera de Valldemossa km. 7.5, E-07122 \\ Palma de Mallorca, Illes Balears, Spain
}

\begin{abstract}
A number of analytical methods have been developed in the past decades for environmental monitoring of plutonium $(\mathrm{Pu})$ isotopes around nuclear facilities, emergency preparedness as well as for risk assessment of contaminated areas resulting from nuclear weapon tests, nuclear accidents, and the discharge of nuclear waste. This article summarizes and critically compares recently reported methods for determination of $\mathrm{Pu}$ isotopes in waters and environmental solid substrates, in which sample pre-treatment is imperative for separation of the target species from matrix ingredients and/or potentially interfering radionuclides prior to detection by radiometric or mass spectrometric detection techniques. Also discussed, via representative examples, is the automation of the entire analytical protocol by on-line extraction chromatography and ion exchange chromatography using flow injection (FI) or sequential injection (SI) approaches.
\end{abstract}

\footnotetext{
${ }^{*}$ Corresponding author. Tel.: +45 46775357.

** Corresponding author. Tel.: +34 971172746.

E-mail addresses: xiaolin.hou@risoe.dk (X. L. Hou), manuel.miro@uib.es (M. Miró)
} 
Keywords: Plutonium; Environment; Extraction chromatography; Ion exchange chromatography; Mass spectrometry;

Radiometry; Flow analysis; Automation

\section{Contents}

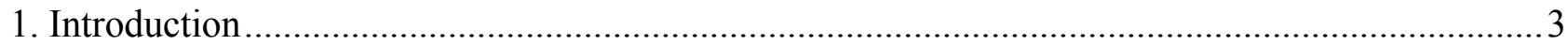

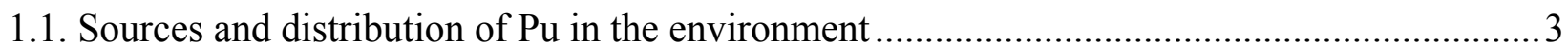

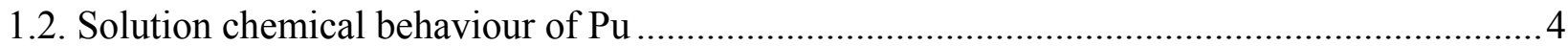

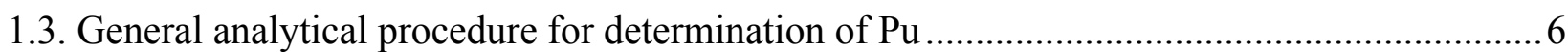

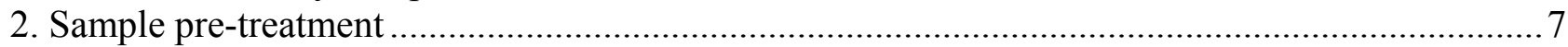

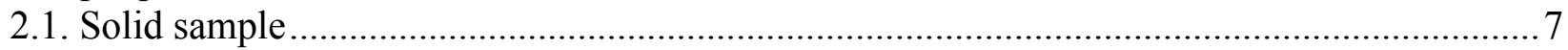

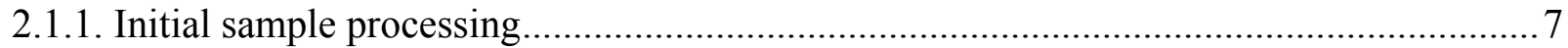

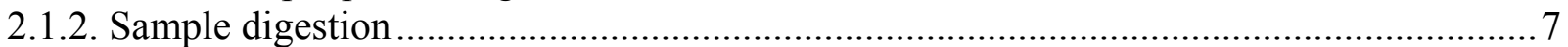

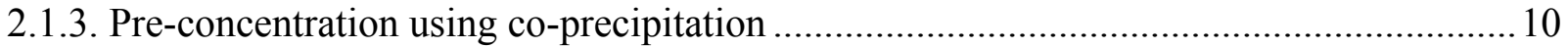

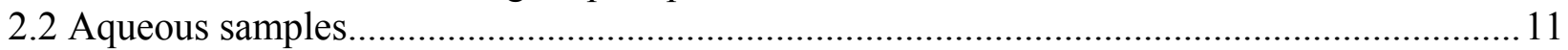

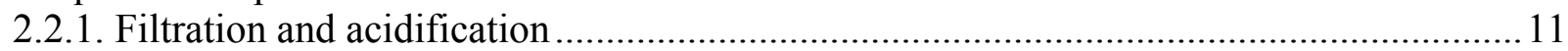

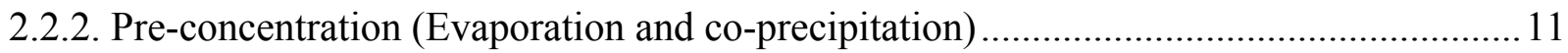

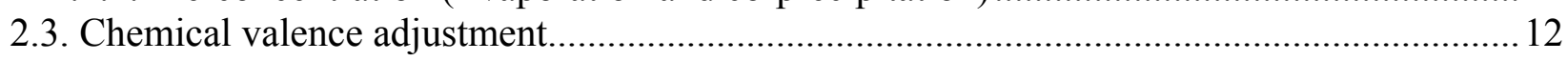

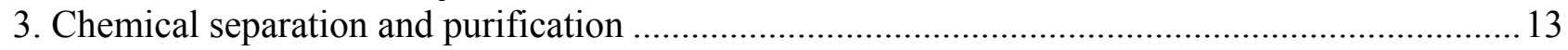

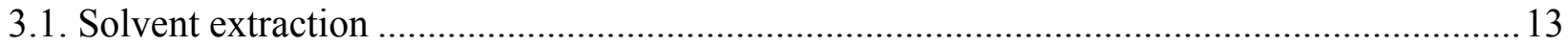

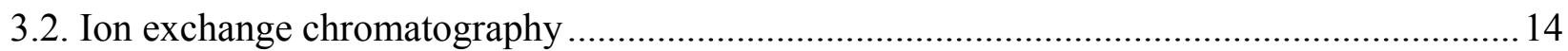

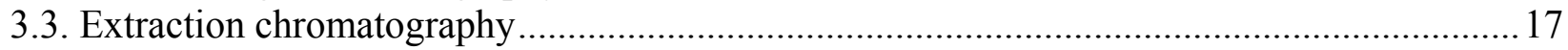

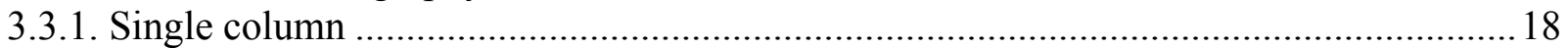

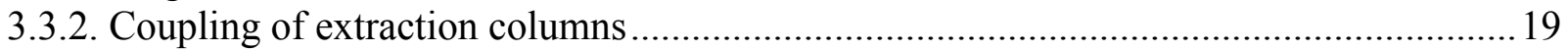

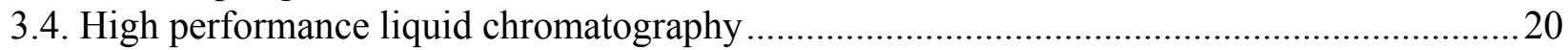

3.5. Combination of different chemical separation methods ................................................... 21

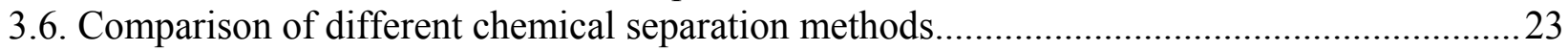

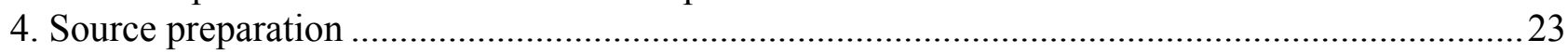

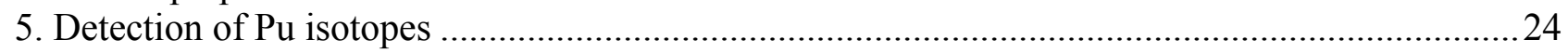

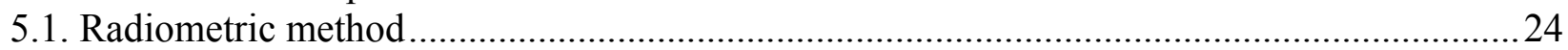

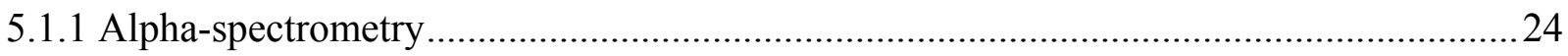

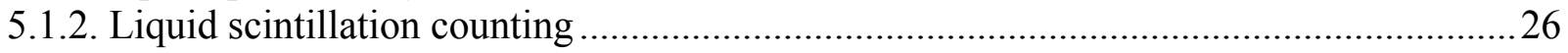

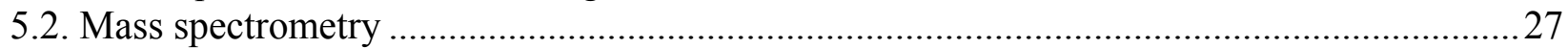

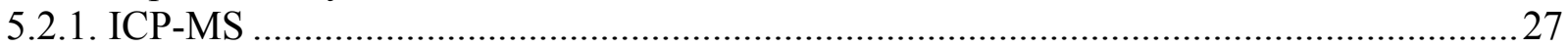

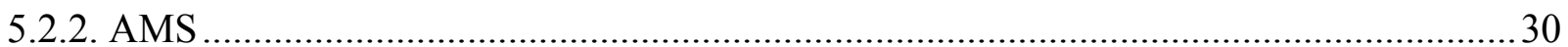

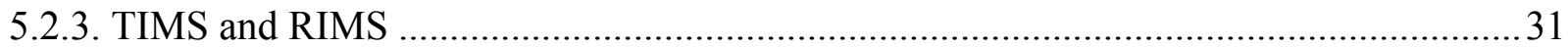

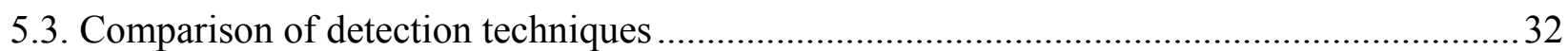

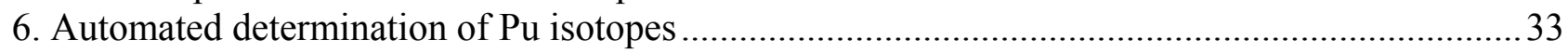

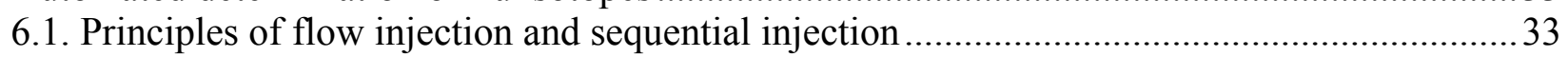

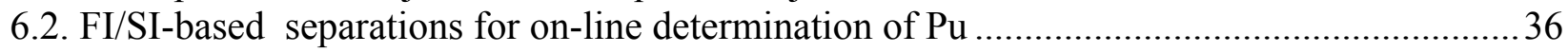

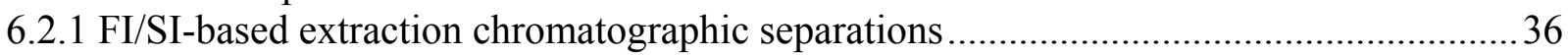

6.2.2. FI/SI-based ion exchange chromatographic separations.............................................. 40

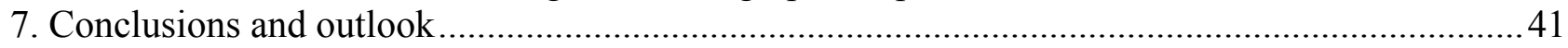

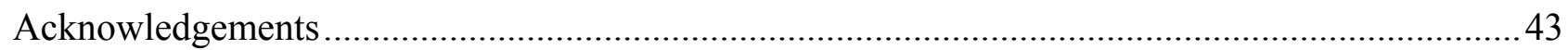

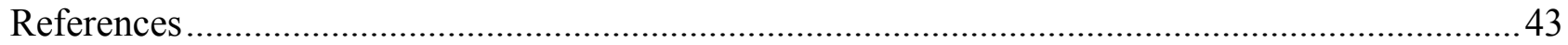


Abbreviations: AMS, accelerator mass spectrometry; EC, electron capture; ETV, electrothermal vaporization; FI, flow-injection; HDEHP, 2-ethylhexyl phosphoric acid; HPLC, high performance liquid chromatography; ICP-MS, inductively coupled plasma mass spectrometry; ICP-QMS, inductively coupled plasma quadrupole mass spectrometry; ICP-SFMS, inductively coupled plasma sector field mass spectrometry; LSC, liquid scintillation counter; MS, mass spectrometry; REEs, rare earth elements; RIMS, resonance ionization mass spectrometry; SI, sequential injection; TIMS, thermal ionization mass spectrometry; TOA, trioctylamine-xylene; TOPO, tri- $n$-octylphosphine oxide; TTA, thenoyl trifluoroacetone.

\section{Introduction}

\subsection{Sources and distribution of Pu in the environment}

$\mathrm{Pu}$ isotopes are regarded as highly hazardous pollutants in the environment due to their radiological toxicities and very long radioactive half-lives, which lead to long-term persistence in the environment $[1,2]$. Among the 20 isotopes of $\mathrm{Pu}$ with mass numbers ranging from 228 to 247 , as presented in Table $1,{ }^{238} \mathrm{Pu},{ }^{239} \mathrm{Pu},{ }^{240} \mathrm{Pu}$ and ${ }^{241} \mathrm{Pu}$ with half-lives of $87.7 \mathrm{yr}, 24110 \mathrm{yr}, 6561 \mathrm{yr}$ and $14.35 \mathrm{yr}$, respectively, are the most frequently monitored in environmental studies[3]. $\mathrm{Pu}$ isotopes are released into the environment as a result of human nuclear activities including nuclear weapons testing and accidents, satellites and reactors accidents (e.g., Systems for Nuclear Auxiliary Power generator (SNAP) in 1964; Palomares in 1966; Thule in 1968 and Chernobyl in 1986) and discharges from nuclear reprocessing facilities and nuclear power plants as well [4-20]. As shown in Table 2, Pu liberated in nuclear weapons testing, particularly in the late 1950s and early 1960s, is by far the largest source of $\mathrm{Pu}$ in the environment, from which the total fallout of $330 \mathrm{TBq}$ of ${ }^{238} \mathrm{Pu}$, 7.4 PBq of ${ }^{239} \mathrm{Pu}, 5.2 \mathrm{PBq}$ of ${ }^{240} \mathrm{Pu}, 170 \mathrm{PBq}$ of ${ }^{241} \mathrm{Pu}$ and $16 \mathrm{TBq}$ of ${ }^{242} \mathrm{Pu}$ were estimated in 1989[4]. However, the distribution characteristics of Pu are strongly influenced by the occurrence in different environmental compartments, such as atmosphere, terrestrial environment, aquatic environment, and the concentrations of $\mathrm{Pu}$ isotopes might vary with the location of the sites and 
transportation within and between environmental media. Table 3 summarizes the distribution of ${ }^{238} \mathrm{Pu}$ and ${ }^{239+240} \mathrm{Pu}$ in some specific oceans and locations related to nuclear accidents.

\subsection{Solution chemical behaviour of $\mathrm{Pu}$}

$\mathrm{Pu}$ ions in solution commonly exist in $\mathrm{Pu}(\mathrm{III}), \mathrm{Pu}(\mathrm{IV}), \mathrm{Pu}(\mathrm{V})$ and $\mathrm{Pu}(\mathrm{VI})$ oxidation states, and each oxidation state can be prepared and stabilized in solution under appropriate conditions [28]. The chemical properties of $\mathrm{Pu}$ change to large extent depending on the oxidation state. $\mathrm{Pu}$ ions in the lower oxidation states (III and IV) are more stable under acid conditions, yet $\mathrm{Pu}(\mathrm{VI})$ is more stable under alkaline media. $\mathrm{Pu}(\mathrm{IV})$ is the most stable and studied oxidation state, followed by $\mathrm{Pu}(\mathrm{III})$ and $\mathrm{Pu}(\mathrm{VI})$. Under non-complexing strongly acidic conditions, such as perchloric or trifluoromethanesulfonic acid (triflic acid) solutions, both $\mathrm{Pu}(\mathrm{III})$ and $\mathrm{Pu}(\mathrm{IV})$ exist as the simple hydrated (or aquo) ions, $\mathrm{Pu}^{3+}{ }_{\text {(aq) }}$ or $\mathrm{Pu}^{4+}{ }_{\text {(aq) }}$, retaining their overall formal charge. $\mathrm{Pu}(\mathrm{V})$ and $\mathrm{Pu}(\mathrm{VI})$ cations have such large positive charges that they immediately hydrolyze in aqueous solution to form dioxocations, $\mathrm{PuO}_{2}{ }^{+}$and $\mathrm{PuO}_{2}{ }^{2+}$, which are commonly referred to as plutonyl ions.

One of the most complex aspects of the aqueous chemistry of $\mathrm{Pu}$ is related to the oxidationreduction relationships of $\mathrm{Pu}$ ions. The corresponding electrochemical potentials of the redox couples of $\mathrm{Pu}$ are given in Table 4. The redox couples of $\mathrm{Pu}(\mathrm{V}) / \mathrm{Pu}(\mathrm{III}), \mathrm{Pu}(\mathrm{VI}) / \mathrm{Pu}(\mathrm{III})$, $\mathrm{Pu}(\mathrm{V}) / \mathrm{Pu}(\mathrm{IV})$, and $\mathrm{Pu}(\mathrm{VI}) / \mathrm{Pu}(\mathrm{IV})$ are quasireversible or irreversible because they involve the breaking or forming of multiple $\mathrm{Pu}=\mathrm{O}$ bonds. In contrast, the redox couples between species without forming or breaking of $\mathrm{Pu}=\mathrm{O}$ bonds, such as $\mathrm{Pu}(\mathrm{IV}) / \mathrm{Pu}(\mathrm{III}), \mathrm{Pu}(\mathrm{VI}) / \mathrm{Pu}(\mathrm{V})$, and $\mathrm{Pu}(\mathrm{VII}) / \mathrm{Pu}(\mathrm{VI})$, are reversible. Since the redox couples that connect the four oxidation states (III, IV, V, and VI) are relatively similar, the overall oxidation states might coexist under appropriate solution conditions.

A large number of reagents have been used for the oxidation or reduction of $\mathrm{Pu}$, some of them are summarized in Table 5. The reactions involving formation or rupture of a metal-oxygen bond, as in 
$\mathrm{Pu}(\mathrm{IV}) / \mathrm{Pu}(\mathrm{VI})$ and $\mathrm{Pu}(\mathrm{IV}) / \mathrm{Pu}(\mathrm{V})$ pairs, are inherently slow. In many cases, the reduction of $\mathrm{Pu}(\mathrm{VI})$ to $\mathrm{Pu}(\mathrm{IV})$ proceeds through the formation of $\mathrm{Pu}(\mathrm{V})$, which then disproportionates to produce $\mathrm{Pu}(\mathrm{IV})$ and $\mathrm{Pu}(\mathrm{VI})$. Nitrite ion plays an important role in $\mathrm{Pu}$ aqueous processing. It is capable of oxidizing $\mathrm{Pu}(\mathrm{III})$ to $\mathrm{Pu}(\mathrm{IV})$ and of reducing $\mathrm{Pu}(\mathrm{VI})$ to $\mathrm{Pu}(\mathrm{IV})$. Since most aqueous processes, e.g. ion exchange chromatography and extraction chromatography rely on $\mathrm{Pu}(\mathrm{IV}), \mathrm{NaNO}_{2}$ is frequently employed as a valence adjuster to convert $\mathrm{Pu}$ to the tetravalent state. Because the $\mathrm{Pu}(\mathrm{VI})$ to $\mathrm{Pu}(\mathrm{IV})$ reduction by nitrite is slow, often another reducing agent, such as ferrous ion is also added to increase the rate of the reaction. Hydroxylamine and hydrazine are also suitable reducing agents for plutonium in high oxidation states, because they are non-metallic, yield volatile oxidation products, and tend to react rapidly.

The coordination chemistry of Pu ions is distinctive of exceptionally "hard" Lewis acids. Weak Lewis bases, such as hydrogen sulfide, generate weak complexes with $\mathrm{Pu}$ and strong Lewis bases, such as carbonate, fluoride and orthophosphate form very stable complexes. Pu ions have relatively large ionic radii and therefore give rise to complexes with high coordination numbers (8-14). For a given ligand the strength of complexes and the liability of ions to hydrolyze decrease following the effective charges:

$$
\mathrm{Pu}^{4+}>\mathrm{Pu}^{3+} \approx \mathrm{PuO}_{2}^{2+}>\mathrm{PuO}_{2}^{+}
$$

In many cases, the processing of samples for separation of $\mathrm{Pu}$ is carried out in $\mathrm{HNO}_{3}$ or $\mathrm{HCl}$ media. Therefore, the knowledge of complexing behaviour of $\mathrm{Pu}$ ions with $\mathrm{NO}_{3}^{-}$and $\mathrm{Cl}^{-}$is imperative. Table 6 shows the formation of complexes of $\mathrm{Pu}$ ions with $\mathrm{NO}_{3}{ }^{-}$and $\mathrm{Cl}^{-}$. It should be however noticed that the stability constants of $\mathrm{Pu}^{3+}$ complexes with $\mathrm{NO}_{3}{ }^{-}$are rather questionable because of $\mathrm{Pu}(\mathrm{III})$ ions are most likely oxidated in a $\mathrm{HNO}_{3}$ medium. 


\subsection{General analytical procedure for determination of $\mathrm{Pu}$}

Because of the potential hazards of $\mathrm{Pu}$ isotopes on human health, the accurate and reliable determination of these radionuclides in environmental samples is important for i) environmental risk assessment and monitoring of the environment around nuclear facilities, such as nuclear power plants, nuclear fuel reprocessing plants and nuclear waste storage sites; ii) emergency preparedness; and iii) surveillance of contaminated areas from nuclear weapon tests, nuclear accidents, and discharges of nuclear wastes. So far, a large number of analytical methods have been devised and exploited for the determination of $\mathrm{Pu}$ in various environmental samples, such as soil, sediment, airborne particulate matter, seawater, groundwater, surface water and wastewater. In general, the whole procedure, as presented schematically in Fig. 1, can be divided into four steps: initial sample pre-treatment, chemical separation and purification, source preparation, and detection. Different approaches utilized in each step are discussed in the text with relevant examples taken from published articles.

Attention is also paid to recent trends in automation of the entire analytical procedure via flowbased approaches. Flow injection (FI) analysis, and related techniques thereof, e.g., sequential injection (SI) analysis, represent a well documented tool for mechanization of analytical assays, with numerous applications in the biochemical, environmental, clinical, and process analysis fields [33-37]. The inherent features of SI in terms of versatility, self-adaptation, full computer control, minimum consumption of sample and reagents, minute waste generation and instrumental robustness make it very attractive for automation and simplification of various sample processing techniques, including liquid-liquid (micro)extraction and solid-phase extraction (SPE) [38-44]. In fact, a vast number of on-line FI/SI-SPE methods have been recently developed for the analysis of environmental samples. Considering the type of chromatographic methods utilized in the separation procedure, these analytical methods can be sorted into two categories, i.e. FI/SI-based extraction 
chromatography and FI/SI-based ion-exchange chromatography, which are overviewed in this paper as well.

\section{Sample pre-treatment}

\subsection{Solid sample}

\subsubsection{Initial sample processing}

At the beginning of the pre-treatment of solid samples (e.g., soil, sediment), large materials with diameters $>2 \mathrm{~mm}$ (e.g., gravel and plant roots) should be removed by sieving. Solid samples are usually dried at $60-105^{\circ} \mathrm{C}$ [45-51] and then ground and further sieved before ensuing treatments. Organic matter in the solid samples can be decomposed by dry ashing in muffle furnaces at 400-700 ${ }^{\circ} \mathrm{C}$ for $2-24 \mathrm{~h}[45,49,52,53]$. A tracer should be added to the sample before analysis in order to estimate the chemical yield of $\mathrm{Pu}$ isotopes during the analytical procedure. The tracer ideally needs to be preferably measured by the same detection technique as the analyte. In the case of $\mathrm{Pu}$ determination, ${ }^{242} \mathrm{Pu}$ (sometimes ${ }^{236} \mathrm{Pu}$ or ${ }^{244} \mathrm{Pu}$ ), an alpha-particle emitter, is often used as the tracer because it is normally not found in significant quantity in environmental samples, and is not a dominant constituent of nuclear fuels or waste waters.

\subsubsection{Sample digestion}

Before further chemical separation, $\mathrm{Pu}$ isotopes should be released from the sample matrix into solution. The ash is frequently decomposed either by acid digestion or alkali fusion. Acid extraction is normally performed in a chemical resistant beaker on a hotplate at atmospheric pressure or in a closed digestion vessel at elevated pressures and temperatures in a microwave oven. Two common methods for releasing of $\mathrm{Pu}$ are acid leaching (partial digestion) and total dissolution. In most cases of acid leaching, concentrated $\mathrm{HNO}_{3}[45,54,55], 8 \mathrm{~mol} \mathrm{~L}^{-1} \mathrm{HNO}_{3}[56], 8 \mathrm{~mol} \mathrm{~L}-1 \mathrm{HNO}_{3}-6 \mathrm{~mol} \mathrm{~L}^{-1}$ 
$\mathrm{HCl}$ [57], 8 mol L ${ }^{-1} \mathrm{HNO}_{3}$-concentrated $\mathrm{H}_{2} \mathrm{O}_{2}$ [49, 58], 6 mol L ${ }^{-1} \mathrm{HCl}$ [47] or aqua regia [59] have been utilized as acid extractants under heating and reflux on a hot plate $\left(180-200^{\circ} \mathrm{C}\right)$ without stirring for 2-6 hours. In the case of significant proportions of refractory $\mathrm{Pu}$ oxides (e.g. $\left.\mathrm{PuO}_{2}\right)$ in the samples (e.g. hot particles form by fire, such as those found in the Thule accident), HF in combination with other acids (e.g. $\mathrm{HNO}_{3}, \mathrm{HCl}, \mathrm{HClO}_{4}$ ) can be a choice for total dissolution of the matrix and release of the entire $\mathrm{Pu}$ in the sample [50, 60-62]. Aimed at accelerating the digestion speed, improving extraction efficiencies and reducing reagent volumes, the application of microwave has attracted the interest of many researchers [49, 50, 54, 58, 61, 63-65]. Toribio et al. [65], for example, achieved total mineralization of soil and sediment samples in $2.5 \mathrm{~h}$ by microwave-assisted dissolution with mixtures of $\mathrm{HF}-\mathrm{HNO}_{3}$ and $\mathrm{HF}-\mathrm{HClO}_{4}$. However, the experimental results with real samples lead to the conclusion that the implementation of a microwave digestion step prior to chemical separation procedures for $\mathrm{Pu}$ caused low recoveries $(61 \pm 8 \%)$. The investigation of potential causes for low Pu recovery demonstrated that the loss of $\mathrm{Pu}$ was neither induced by volatilisation whenever $\mathrm{HF}-\mathrm{HClO}_{4}$ mixtures were used, nor related to the presence of fluoride as a potential interference in the digest. Therefore, further studies are needed to focus on the influence of other matrix components on the separation process applied after digestion (see below).

Alkali fusion is an extremely aggressive method performed by heating the sample with a mixture of various fluxes (e.g. hydroxides, peroxides, carbonates, hydrosulfates, pyrosulfates or alkali borates) at atmospheric pressure in a graphite, nickel, zirconium, or platinum crucible [48, 66, 67]. The mixture is heated to a temperature above the melting point of the flux over a burner or in a muffle furnace until the mixture form a well-mixed molten mass. After cooling, the resulting fusion cake is dissolved with a diluted acid such as $\mathrm{HNO}_{3}$ or $\mathrm{HCl}$. Croudace et al. [66] described a method in which borate fusion was used as sample pre-treatment. In this method, a eutectic mixture of $80 \%$ 
lithium metaborate and $20 \%$ lithium tetraborate was mixed with pre-ignited samples. Fusions were performed in grain-stabilised, $\mathrm{Pt}-\mathrm{Au}(95 \% / 5 \%)$ dishes at $1200^{\circ} \mathrm{C}$ in a resistance-type furnace. The main safety benefit of the described technique is the limited use of acids and the absence of HF. Warwick et al. [48] applied lithium borate fusion for soil and sediment pre-treatment. The use of this flux permitted the complete dissolution of potentially intractable materials and thus ensured the complete recovery of refractory $\mathrm{Pu}$ oxides. They claimed that the lithium borate fusion was preferable to the more conventional HF digestion or fusion with potassium fluoride for safety reasons.

Summing up, acid leaching is not only the simplest method but suits to the pre-treatment of large sample amounts. However, acid leaching might give rise to poor recoveries for samples containing high proportion of refractory $\mathrm{Pu}$ oxides. Although refractory phases hosting $\mathrm{Pu}$ are more likely to be extracted by digestion methods using HF, potential dissolution of interfering elements, such as iron, phosphorus, and other rare-earths is also increased. After matrix dissolution HF should be removed either by fuming with $\mathrm{HClO}_{4}$ or $\mathrm{H}_{2} \mathrm{SO}_{4}$ or by complexation with $\mathrm{H}_{3} \mathrm{BO}_{3}$ or aluminium in order to facilitate further chemical separations, whereby special extraction facilities for HF vapours and associated safety equipment is needed. Sometimes a combination of the above methods is chosen. A simple way to remove fluoride ions is to dilute the sample and co-precipitate $\mathrm{Pu}$ with $\mathrm{Fe}(\mathrm{OH})_{3}$, fluoride ions then remain in the aqueous phase. The application of microwave digestion has the advantages of high efficiency, decreased operational time and consumption of reagents, but the sample amount to be digested is limited to a few hundreds of milligrams. In alkali fusion, however, samples are completely decomposed and $\mathrm{Pu}$ losses in the residue are kept to minimum. It is therefore one of the most effective methods of digestion for solid sample containing silicates and refractory $\mathrm{Pu}$. Fusion is normally applicable to large sample amounts (several grams) but becomes unreliable when exceeding 5-10g, which however in many instances are needed [66, 68]. A 
drawback of the alkaline fusion is the aggressiveness of the reaction that might lead to the addition of crucible components to the sample matrix.

\subsubsection{Pre-concentration using co-precipitation}

Co-precipitation is a traditional method for the pre-concentration and removal of matrix components in sample extracts or digests following acid leaching/digestion or alkali fusion. The most frequently used reagents for $\mathrm{Pu}$ co-precipitation are fluorides (e.g., $\left.\mathrm{NdF}_{3}, \mathrm{LaF}_{3}, \mathrm{CeF}_{3}\right)[46,61$, 69], $\mathrm{Fe}(\mathrm{OH})_{2}$ or $\mathrm{Fe}(\mathrm{OH})_{3}[49,57,67]$, phosphates $\left(\mathrm{CaHPO}_{4}, \mathrm{Ca}_{3}\left(\mathrm{PO}_{4}\right)_{2}\right)[70]$, calcium oxalate $\left(\mathrm{CaC}_{2} \mathrm{O}_{4}\right)$ [45]. Co-precipitation of $\mathrm{Pu}(\mathrm{IV})$ with rare earth fluorides (e.g., $\left.\mathrm{NdF}_{3}\right)$ is a common method for preliminary separation of $\mathrm{Pu}[64,66]$ because co-precipitation of U(VI) is not favoured, and hereby the interfering effects of uranium are lessened. Co-precipitation with $\mathrm{Fe}(\mathrm{OH})_{3}$ or $\mathrm{Fe}(\mathrm{OH})_{2}[53,63]$ is the method of choice for isolation of $\mathrm{Pu}$ from large volumes of carbonate-free water samples (100-500 L). On the other hand, co-precipitation of $\mathrm{Pu}(\mathrm{III})$ and $\mathrm{Pu}(\mathrm{IV})$ with $\mathrm{CaC}_{2} \mathrm{O}_{4}$ is preferred for those samples containing high concentration of iron, because iron forms a soluble complex with oxalic acid within $\mathrm{pH}$ 5.5-6.0, and remains in the solution during co-precipitation of $\mathrm{Pu} . \mathrm{CaF}_{2}$-based co-precipitation $[54,71]$ has been proven effective for isolation of $\mathrm{Pu}$ from soils and sediments. In this method, co-precipitation is performed with the addition of $\mathrm{Ca}\left(\mathrm{NO}_{3}\right)_{2}$ to the acidic extract/digest followed by a reducing agent $\left(\mathrm{NH}_{2} \mathrm{OH} \cdot \mathrm{HCl}\right)$ and concentrated $\mathrm{HF}$.

Notwithstanding the fact that $\mathrm{Fe}(\mathrm{OH})_{2}$ or $\mathrm{Fe}(\mathrm{OH})_{3}$ are the most commonly used co-precipitation reagents for uptake of $\mathrm{Pu}, \mathrm{CaF}_{2}$ and rare earth-fluoride co-precipitations have the advantageous features of being carried out in strong acidic media. Thus, there is no risk of precipitation of the main matrix components (e.g. alkali metals and most transition metals) and possible interfering compounds for chemical separation (e.g. phosphate, sulphate) or detection (e.g. U). 


\subsection{Aqueous samples}

\subsubsection{Filtration and acidification}

In order to fractionate $\mathrm{Pu}$ between dissolved species and those associated to suspended particulate matter, water samples (e.g., seawater, freshwater, groundwater) should be filtered through appropriate filters before acidification to $\mathrm{pH} 1-2$. Acidification should be performed immediately after sample collection as hydrolysed $\mathrm{Pu}$ species have great affinity towards exposed surfaces, including the walls of the container. The tracer should be added after acidification as hydrolysis of the tracer can lead to an uneven distribution within the sample.

\subsubsection{Pre-concentration (Evaporation and co-precipitation)}

Plutonium is found in environmental waters, e.g., seawater, at much lower concentration (typically within the femtograms per litre range) than in other types of environmental samples. Accordingly, large volume sampling and labour-intensive sample pre-treatments are essential for accurate determination of $\mathrm{Pu}$ in water. For instance, appropriate method sensitivity is merely achieved whenever sample volumes of 100-200 L water are processed. The analyte should therefore be concentrated to a smaller volume before further chemical separations take place. Evaporation is sometimes used for pre-concentration purposes for samples with low salt content, but it is inadequate for neither processing large sample volumes (>10 L) nor samples containing high levels of total dissolved solids, such as seawater. In these circumstances, co-precipitation can be the method of choice for trace level determinations of Pu. Schaumloffel et al. [72] applied coprecipitation with $\mathrm{MnO}_{2}$ and $\mathrm{Fe}(\mathrm{OH})_{3}$ in different steps to pre-concentrate $\mathrm{Pu}$ from $10 \mathrm{~L}$ tap water down to $125 \mu \mathrm{L}$. $\mathrm{Fe}(\mathrm{OH})_{2}, \mathrm{Fe}(\mathrm{OH})_{3}$ and $\mathrm{MnO}_{2}$ have also been extensively used for preconcentration of $\mathrm{Pu}$ from large volumes of freshwater and seawater [62, 73]. Chen et al. [73], for example, pre-concentrated $\mathrm{Pu}$ in $200 \mathrm{~L}$ of seawater by co-precipitation with $\mathrm{Fe}(\mathrm{OH})_{2}$. The $\mathrm{pH}$ was 
controlled to 8.5-9.0 during the co-precipitation procedure to minimize the formation of $\mathrm{Ca}(\mathrm{OH})_{2}$ and $\mathrm{Mg}(\mathrm{OH})_{2}$ side products. During field-based sampling it might however be advantageous to exploit a large $\mathrm{Ca}+\mathrm{Mg}+\mathrm{Fe}$ hydroxide precipitate for ease of handling and minimisation of redistribution of precipitate by wind and wave action. In the laboratory the bulky precipitate may be dissolved and again precipitated using ammonium/ammonia buffer up to about $\mathrm{pH} 8-9$ which then causes only $\mathrm{Fe}(\mathrm{OH})_{3}$ to precipitate. Norisuye et al. [74] developed a method to pre-concentrate $\mathrm{Pu}$ from several thousand litres of seawater using $\mathrm{MnO}_{2}$-impregnated fibers. By this means $\mathrm{Pu}$ can be on-board extracted, making the transportation of large volume of seawater unnecessary. The recoveries of ${ }^{239+240} \mathrm{Pu}$ using $\mathrm{MnO}_{2}$-impregnated fibers ( $\left.>95 \%\right)$ were higher than those obtained by previous techniques [69]. However, compared to the precipitation with $\mathrm{Fe}(\mathrm{OH})_{2}$ and/or $\mathrm{Fe}(\mathrm{OH})_{3}$, the removal of $\mathrm{Mn}$ from the final precipitate is frequently somewhat more troublesome.

For both solid and liquid environmental samples, the precipitate containing $\mathrm{Pu}$ should be separated by filtration or centrifugation. After washing, it is dissolved with $\mathrm{HNO}_{3}$ or $\mathrm{HCl}$ afterwards.

\subsection{Chemical valence adjustment}

In the environment, $\mathrm{Pu}$ can coexist in several oxidation states with different chemical behaviours. It is therefore imperative to ensure that the chemical procedure employed does not discriminate between $\mathrm{Pu}$ isotopes in the sample and the added tracer as well. To the end, the conversion of the overall $\mathrm{Pu}$ to a single oxidation state is usually performed by an unequivocal redox cycle before further chemical separation. Under most conditions, $\mathrm{Pu}$ is converted to $\mathrm{Pu}(\mathrm{IV})$ and, in some cases, to $\mathrm{Pu}(\mathrm{III})$. To this point, a variety of redox reagents have been used, namely, $\mathrm{NaNO}_{2}$ [45], $\mathrm{Fe}\left(\mathrm{NH}_{2} \mathrm{SO}_{3}\right)_{2} \cdot 6 \mathrm{H}_{2} \mathrm{O}$ and $\mathrm{NaNO}_{2}(\mathrm{~s})-\mathrm{HNO}_{3}$ [56], $\mathrm{H}_{2} \mathrm{O}_{2}-\mathrm{Na}_{2} \mathrm{~S}_{2} \mathrm{O}_{3}-\mathrm{NaNO}_{2}$ [73], $\mathrm{N}_{2} \mathrm{H}_{4} \cdot \mathrm{H}_{2} \mathrm{O}-\mathrm{NaNO}_{2}(\mathrm{~s})$ [50], $\mathrm{NH}_{2} \mathrm{OH} \cdot \mathrm{HCl}-\mathrm{NaNO}_{2}(\mathrm{~s})$ [49], and $\mathrm{Fe}\left(\mathrm{NH}_{2} \mathrm{SO}_{3}\right)_{2} \cdot 6 \mathrm{H}_{2} \mathrm{O}-$ Ascorbic acid [65] (see Table 6 for further information). 


\section{Chemical separation and purification}

The accuracy and precision of most analytical methods for $\mathrm{Pu}$ determination are often deteriorated because of non-specific interferences occasioned by more abundant sample matrix species and spectrometric or isobaric interferences from other nuclides. For example, ${ }^{241} \mathrm{Am}$, as an alpha emitter with decay energy of $5.443 \mathrm{MeV}(13 \%)$ and $5.486 \mathrm{MeV}(86 \%)$, interferes the measurement of ${ }^{238} \mathrm{Pu}$ (decay energy $5.456 \mathrm{MeV}(72 \%)$ ) by alpha-spectrometry, while ${ }^{238} \mathrm{U}$ often gives rise to tailing and isobaric effects by the formation of polyatomic ions ${ }^{238} \mathrm{U}^{1} \mathrm{H}$ and ${ }^{238} \mathrm{U}^{2} \mathrm{H}$ during the detection of ${ }^{239} \mathrm{Pu}$ and ${ }^{240} \mathrm{Pu}$, respectively, using inductively coupled plasma mass spectrometry (ICP-MS). More details of interferences in the determination of $\mathrm{Pu}$ isotopes are given in Table 7. These interferences often necessitate chemical separation of $\mathrm{Pu}$ from the interfering species before detection. Additionally, chemical separations are usually designed to concentrate $\mathrm{Pu}$, which is needed in environmental assays because of the low level concentrations of the target radionuclide as commented above. For separation and purification of $\mathrm{Pu}$, a variety of techniques have been used, yet the most common are solvent extraction, ion exchange chromatography, extraction chromatography, high performance liquid chromatography or a combination of two or more methods $[3,60]$. Table 8 compiles the analytical performance of reported procedures using different separation methods for determination of $\mathrm{Pu}$ in waters and environmental solids.

\subsection{Solvent extraction}

Solvent extraction is frequently exploited in the reprocessing of spent fuel and treatment of radioactive waste. Several extraction reagents have been reported for the separation and preconcentration of Pu including TBP (tri-butyl phosphate), TIOA (triisooctylamine)-xylene [51, 75], TTA (thenoyltrifluoroacetone)-benzene [74], HDEHP(di-2(ethylhexyl)-phosphoric acid) [76, 77] 
and TOPO (tri-n-octylphosphine oxide) [78]. For instance, Norisuye et al. [74] purified Pu from a large volume of seawater by solvent extraction using TTA-benzene. The recoveries of $\mathrm{Pu}$ within the solvent extraction stage amounted to $96 \pm 2 \%$. Monmoshima et al. [51] carried out the separation of $\mathrm{Pu}$ from pine needle, litter and sediment samples using 10\% (w/v) TIOA-xylene. Pu in an $8 \mathrm{~mol} \mathrm{~L}^{-1}$ $\mathrm{HNO}_{3}$ medium was extracted with TIOA-xylene twice, followed by back-extraction with a $0.1 \mathrm{~mol}$ $\mathrm{L}^{-1} \mathrm{NH}_{4} \mathrm{I}-8.5 \mathrm{~mol} \mathrm{~L}^{-1} \mathrm{HCl}$ solution. In the early days, solvent extraction played an important role for the separation of $\mathrm{Pu}$ in environmental samples. Solvent extraction offers the great advantage of selection among numerous extractants whereby the selectivity can be readily modulated, however, it is deemed too labour-consuming for routine analysis because several extractions should be consecutively performed to completely separate the analyte from the bulk solution. Difficulties in phase separation and the mutual solubility of the two phases might result in a significant loss of the analyte. Furthermore, a large volume of residual hazardous organic solvents is obtained. Nowadays, as the rapid development of extraction chromatography and ion exchange chromatography techniques, solvent extraction is not often used as a routine method for chemical separation of $\mathrm{Pu}$ in environmental samples. However, it is flexible, and still offers some very attractive features when single samples are analysed. For example, the separation of $\mathrm{Pu}$ using solvent extraction with the combination of TBP and TTA, requires less than $1 \mathrm{~h}$ for complete separation and making the eluate ready for injection to ICP-MS or alpha spectrometry.

\subsection{Ion exchange chromatography}

Because of the high ionic potential as well as its proclivity to form anionic complexes, Pu might be eventually adsorbed onto either cation exchangers or anion exchangers. In the presence of ion exchange resins, $\mathrm{Pu}$ complexes will exchange with ions of the same charge on the resin if the overall free energy lowered after the exchange. Ion exchange separation using large-size columns is 
therefore a common technique for isolation of $\mathrm{Pu}$ in complex matrices. Due to the pronounced ability of actinides in the higher oxidation states to form anionic complexes, anion exchange chromatography using Dowex 1(or Bio-Rad AG 1 or AG MP-1) resins [49, 50, 56, 59, 62, 73, 79], is the most widely accepted method, whereas the cation exchange process is seldom employed [80] .

The basis for separation of $\mathrm{Pu}$ on an anion-exchanger relies upon the strong adsorption of anion complexes of $\mathrm{Pu}(\mathrm{IV})$ with $\mathrm{NO}_{3}{ }^{-}$forming in $\mathrm{HNO}_{3}$ medium. Most of the matrix elements cannot form anion complexes under these conditions, and therefore cannot be adsorbed on the column. In addition, the III, $\mathrm{V}$ and VI oxidation states of $\mathrm{Pu}$ and transuranium elements, such as Am, cannot form anionic complexes either. Thorium, like $\mathrm{Pu}(\mathrm{IV})$ forms a strong nitrate complex while uranium only forms a weak complex and therefore might be readily separated from $\mathrm{Pu}$ by anion-exchange in nitric acid media. A general flow sheet for the chemical separation of $\mathrm{Pu}$ via anion-exchange is illustrated in Fig.2 The separation of $\mathrm{Pu}$ from matrix ingredients including radionuclides is generally accomplished by valence adjustment of the analyte, sample loading onto anion-exchange resins in 7-8 mol L-1 $\mathrm{HNO}_{3}$, washing with 7-8 $\mathrm{mol} \mathrm{L}^{-1} \mathrm{HNO}_{3}$ to remove most of the inert matrix species as well as Am and $\mathrm{U}$, washing with 9-12 $\mathrm{mol} \mathrm{L}^{-1} \mathrm{HCl}$ to remove Th, and finally elution of $\mathrm{Pu}$ after reduction using reductant-containing diluted $\mathrm{HNO}_{3}$ or $\mathrm{HCl}$ solution. The latter is preferred since both traces of remaining uranium and Po remain on the resin. In case of solutions containing fluoride, aluminium should be added to preferentially complex the fluoride and improve $\mathrm{Pu}$ recovery.

Taking into account the different valence states of $\mathrm{Pu}$ in environmental samples, a two-step redox procedure is usually needed for selective conversion of the overall $\mathrm{Pu}$ into $\mathrm{Pu}(\mathrm{IV})$. Chen et al. [73], for example, used $\mathrm{NaHSO}_{3}$ for initial reduction of $\mathrm{Pu}$ to $\mathrm{Pu}(\mathrm{III})$, followed by addition of $\mathrm{NaNO}_{2}(\mathrm{~s})$ or concentrated $\mathrm{HNO}_{3}$ to oxidize $\mathrm{Pu}$ (III) to $\mathrm{Pu}(\mathrm{IV})$. Moreno et al. [50] applied Bio-Rad AG $1 \times 8$ 
resin to separate $\mathrm{Pu}$ from soil extracts and utilized $\mathrm{N}_{2} \mathrm{H}_{4} \cdot \mathrm{H}_{2} \mathrm{O}$ and $\mathrm{NaNO}_{2}$ (s) to convert $\mathrm{Pu}$ into $\mathrm{Pu}(\mathrm{IV})$.

For elution of $\mathrm{Pu}$ adsorbed onto anion exchanger, different kinds of reagents have been exploited. For instance, Stürup et al. [59] used Dowex $1 \times 4$ resin and elution with $1.2 \mathrm{~mol} \mathrm{~L}^{-1} \mathrm{HCl}-0.6 \% \mathrm{H}_{2} \mathrm{O}_{2}$ for separation of $\mathrm{Pu}$ in sediments. Diluted iodide (e.g. $\left.\mathrm{NH}_{4} \mathrm{I}, \mathrm{HI}\right)-9$ mol L ${ }^{-1} \mathrm{HCl}[52,53,56]$ as well as $\mathrm{NH}_{2} \mathrm{OH} \cdot \mathrm{HCl}[58,81]$ have been also employed by several researchers as the eluent of $\mathrm{Pu}$.

Montero et al. [49] compared two separation procedures using Dowex $1 \times 8$ resin for the determination of $\mathrm{Pu}$ in soil samples. In the first procedure, $\mathrm{Pu}(\mathrm{IV})$ was stabilized by the addition of $\mathrm{NH}_{2} \mathrm{OH} \cdot \mathrm{HCl}$ and $\mathrm{NaNO}_{2}(\mathrm{~s})$, and loaded onto the resin in $8 \mathrm{~mol} \mathrm{~L}^{-1} \mathrm{HNO}_{3}$. After washing with 8 mol L ${ }^{-1} \mathrm{HNO}_{3}$ and $10 \mathrm{~mol} \mathrm{~L}^{-1} \mathrm{HCl}$, Pu was eluted with $0.1 \mathrm{~mol} \mathrm{~L}^{-1} \mathrm{HI}-9 \mathrm{~mol} \mathrm{~L}{ }^{-1} \mathrm{HCl}$. In the second procedure, $\mathrm{Pu}$ was directly converted to $\mathrm{Pu}(\mathrm{IV})$ by $\mathrm{NaNO}_{2}(\mathrm{~s})$ and loaded in $9 \mathrm{~mol} \mathrm{~L}^{-1} \mathrm{HCl}$. The column was washed consecutively with $10 \mathrm{~mol} \mathrm{~L}^{-1} \mathrm{HCl}$ and $8 \mathrm{~mol} \mathrm{~L}^{-1} \mathrm{HNO}_{3}$. Finally, Pu was eluted with 9 mol L ${ }^{-1} \mathrm{HCl}-\mathrm{H}_{2} \mathrm{O}_{2}$. The first procedure was found to yield higher recoveries than the second one $(60 \%$ vs. $40 \%)$. Besides, a high percentage of $\mathrm{Pu}$ appeared in the $\mathrm{U}$ and $\mathrm{Th}$ fractions in the second procedure, indicating a premature elution of targeted species. The low recovery of the second method might be attributed to the method selected for valence adjustment. In principle, $\mathrm{NaNO}_{2}$ can reduce $\mathrm{Pu}(\mathrm{VI})$ to $\mathrm{Pu}(\mathrm{IV})$ and oxidize $\mathrm{Pu}(\mathrm{III})$ to $\mathrm{Pu}(\mathrm{IV})$, so can virtually adjust $\mathrm{Pu}$ to $\mathrm{Pu}(\mathrm{IV})$. Yet, the reduction of $\mathrm{Pu}(\mathrm{VI})$ to $\mathrm{Pu}(\mathrm{IV})$ needs actually several hours under room temperature for completion if no catalyst is added [82]. With the addition of $\mathrm{Fe}(\mathrm{II})$, the reduction of $\mathrm{Pu}(\mathrm{VI})$ to $\mathrm{Pu}(\mathrm{IV})$ can be promoted [82]. However, because the concentration of $\mathrm{Pu}$ in the environmental samples is very low, the reduction of $\mathrm{Pu}(\mathrm{VI})$ to $\mathrm{Pu}(\mathrm{IV})$ might be still not fast enough to be completed within a few minutes. In this case, the $\mathrm{Pu}(\mathrm{VI})$ fraction which is not converted to $\mathrm{Pu}(\mathrm{IV})$ is to be lost during the separation. The most suitable procedure for quantitative valence adjustment is the reduction of $\mathrm{Pu}$ to $\mathrm{Pu}(\mathrm{III})$ with a strong reductant followed by oxidation of the resulting $\mathrm{Pu}(\mathrm{III})$ 
to $\mathrm{Pu}(\mathrm{IV})$ by nitrite. This procedure is generally fast enough to convert the overall $\mathrm{Pu}$ into $\mathrm{Pu}(\mathrm{IV})$ in a few minutes [82].

\subsection{Extraction chromatography}

Extraction chromatography is an extraction and sample clean-up process performed in a continuous and multi-stage manner on a packed column. In this technique, the stationary phase consists of one or more ionophores dissolved in an organic solvent which is immobilized on a porous support material. The inert support is normally composed of porous silica or organic polymers with particle sizes typically ranging between 50-150 $\mu \mathrm{m}$. Extraction chromatography combines the diversity and selectivity of solvent extraction with the high separation efficiencies of column chromatography.

Over the past few years, extraction chromatography has become a very attractive method for $\mathrm{Pu}$ separation in environmental samples $[46,51,65,67,70-72]$ because of short sample processing times, easy operational procedures and the availability of commercial actinides-specific extraction resins, such as TEVA, TRU and UTEVA from Eichrom Technologies in US or Triskem International in Europe. Similar to the ordinary ion exchange resins, a pre-separation protocol might be needed to remove dissolved salts in large sample volumes to maintain the selectivity and capacity of the resin. Yet, the most severe shortcoming is the lack of a Pu-specific sorbent material, whereby the interference of concomitant $U$, which is frequently found at much higher concentration than $\mathrm{Pu}$, cannot be completely overcome merely by exploiting a single extraction column separation. Therefore, the combination of two or more sorbent materials is applied in the case of samples containing high levels of uranium. 


\subsubsection{Single column}

TEVA, an extraction chromatographic resin developed by Horwitz and co-workers [83] and composed of a quaternary amine-based anion exchanger grafted onto an inert support, has been widely used for uptake of actinides in 2-4 mol L-1 $\mathrm{HNO}_{3}$ or $\mathrm{HCl}$ media. For example, Varga et al. [71] utilized TEVA-based extraction chromatography for the separation of $\mathrm{Pu}$ in seaweed and sediments following stabilization of the target species in the tetravalent state. Extracts in $3 \mathrm{~mol} \mathrm{~L}^{-1}$ $\mathrm{HNO}_{3}$ were loaded on the resin, followed by consecutive rinsing with $3 \mathrm{~mol} \mathrm{~L}^{-1} \mathrm{HNO}_{3}$ and $6 \mathrm{~mol} \mathrm{~L}^{-}$ ${ }^{1} \mathrm{HCl}$. Pu was eluted by $0.1 \mathrm{~mol} \mathrm{~L}^{-1} \mathrm{HNO}_{3}-0.1 \mathrm{~mol} \mathrm{~L}^{-1} \mathrm{HF}$. The proposed method eliminated the eventual interferences of $\mathrm{Th}, \mathrm{Am}, \mathrm{U}, \mathrm{Pb}$ and $\mathrm{Bi}$ in the final detection step. The decontamination factors (the ratio of the amount of the element of interest in the sample to that in the final $\mathrm{Pu}$ fraction) were all above $10^{5}$ for $\mathrm{U}$, Th and $\mathrm{Am}$. The recovery of $\mathrm{Pu}$ ranged from $72 \%$ to $92 \%$ for certified reference materials of sediment. The overall sample separation for one run can be carried out within one day. Momoshima et al. [51] also used TEVA to separate Pu in soils and sediments. Sample loading was carried out in $2 \mathrm{~mol} \mathrm{~L}^{-1} \mathrm{HNO}_{3}$ followed by washing with $8 \mathrm{~mol} \mathrm{~L}^{-1} \mathrm{HNO}_{3}$ and 6 mol L ${ }^{-1} \mathrm{HCl}$. Pu was eluted with a diluted acid solution, namely, $0.5 \mathrm{~mol} \mathrm{~L}^{-1} \mathrm{HCl}$.

TRU is another extraction chromatographic resin often used for the separation of actinides in $\mathrm{HNO}_{3}$ or $\mathrm{HCl}$ media [84]. As opposed to TEVA, TRU resin contains octyl (phenyl)-N,Ndiisobutylcarbamoylmethylphosphine oxide dissolved in tri-n-butyl phosphate. TRU resin has been utilized for a vast number of analytical purposes, including separation of the actinides as a group from the sample matrix; group actinide separation based on the valence state and individual separation of $\mathrm{Am} / \mathrm{Cm}$ and $\mathrm{Pu}$ from each other. Actinides in III, IV and VI oxidation states are strongly retained by TRU in $>0.5 \mathrm{~mol} \mathrm{~L}^{-1} \mathrm{HNO}_{3}$, while most of matrix constituents and potentially interfering radionuclides are not. Am and radionuclides in trivalent oxidation state, which are not retained by TRU resin in $\mathrm{HCl}$ medium, can be eluted from the column with 4-6 mol L $\mathrm{HCl}^{-1} \mathrm{HC}$ 
whereas tetravalent and hexavalent actinides are strongly retained. $\mathrm{Pu}$ is finally selectively eluted by on-column reduction of $\mathrm{Pu}$ to $\mathrm{Pu}(\mathrm{III})$, which is not retained on the column in hydrochloric acid medium. Hence, the other actinides such as $\mathrm{U}, \mathrm{Th}, \mathrm{Np}$ still remain on the column. For instance, Kaye et al. [85] performed the separation of Pu in soil, tank sludge and waste samples by TRU resin using ascorbic acid to reduce iron to $\mathrm{Fe}(\mathrm{II})$ in order to prevent the uptake of Fe(III). The sample was loaded in $2 \mathrm{~mol} \mathrm{~L}^{-1} \mathrm{HNO}_{3}$, followed by $2 \mathrm{~mol} \mathrm{~L}^{-1} \mathrm{HNO}_{3}-\mathrm{NaNO}_{2}$ (s) to retain $\mathrm{Pu}$ as $\mathrm{Pu}(\mathrm{IV})$. $\mathrm{Pu}$ was finally isolated by elution with $0.1 \mathrm{~mol} \mathrm{~L}^{-1}$ hydroquinone- 4 mol L ${ }^{-1} \mathrm{HCl}$ after washing $\mathrm{Am}$ and $\mathrm{Cm}$ off with $4 \mathrm{~mol} \mathrm{~L}^{-1} \mathrm{HCl}$.

\subsubsection{Coupling of extraction columns}

UTEVA, composed of dianylamylphosphonate sorbed on an inert polymeric support, is usually used for the pre-concentration and separation of uranium in $\mathrm{HNO}_{3}$ or $\mathrm{HCl}$ media [86]. In a number of radiochemical procedures, UTEVA resin has been employed in combination with TRU resin [62] and other resins. Toribio et al. [65], for example, devised an extraction chromatographic method for separation of $\mathrm{Pu}$ in soils and sediments by coupling UTEVA and TRU resins in tandem to improve the separation efficiency. In this procedure, $\mathrm{Fe}\left(\mathrm{NH}_{2} \mathrm{SO}_{3}\right)_{2}$ and ascorbic acid were used to reduce $\mathrm{Pu}$ to $\mathrm{Pu}(\mathrm{III})$. The sample in $3 \mathrm{~mol} \mathrm{~L}^{-1} \mathrm{HNO}_{3}$ was passed through the UTEVA resin and delivered to the TRU column. Pu in trivalent state, which should not be sorbed on UTEVA, was loaded on TRU, while U(VI) and Th(IV) were efficiently sorbed on UTEVA column and therefore removed. Pu on the TRU resin was oxidized to $\mathrm{Pu}(\mathrm{IV})$ by $2 \mathrm{~mol} \mathrm{~L}^{-1} \mathrm{HNO}_{3}-0.1 \mathrm{~mol} \mathrm{~L}^{-1} \mathrm{NaNO}_{2}$ in order to wash Am(III) by column rinsing with $\geq 4 \mathrm{~mol} \cdot \mathrm{L}^{-1} \mathrm{HCl}$. Pu was finally eluted by a $0.1 \mathrm{~mol} \mathrm{~L}^{-1}\left(\mathrm{NH}_{4}\right)_{2} \mathrm{C}_{2} \mathrm{O}_{4}$ solution. The average recovery of $\mathrm{Pu}$ was better than $80 \%$. Varga et al. [54] employed a similar

procedure to separate $\mathrm{Pu}$ in sediments and soils. In this case, $\mathrm{Pu}$ in $4 \mathrm{~mol} \mathrm{~L}^{-1} \mathrm{HNO}_{3}$ was reduced to $\mathrm{Pu}(\mathrm{III})$ by $\mathrm{NH}_{2} \mathrm{OH} \cdot \mathrm{HCl}$. Similar Pu yields as those of Toribio et al [65] were obtained. 
Mellado et al. [61] compared three separation methods for the determination of $\mathrm{Pu}, \mathrm{Am}$, Th and $\mathrm{Sr}$ in sediment samples. In the first method, four chromatographic extraction columns were used including two TRU columns, one UTEVA column and one Sr column as well. After addition of $\mathrm{NaNO}_{2}(\mathrm{~s})$, the sample in $4 \mathrm{~mol} \mathrm{~L}^{-1} \mathrm{HNO}_{3}$ was loaded onto the first TRU resin, followed by a washing step with $3 \mathrm{~mol} \mathrm{~L}^{-1} \mathrm{HNO}_{3}$ to remove $\mathrm{Sr}$ along with $\mathrm{Ca}, \mathrm{Al}, \mathrm{Na}, \mathrm{K}$. The remainder of the method involving the UTEVA/TRU tandem has been explained earlier in this section. This method yielded rather low recoveries of $\mathrm{Pu}$, viz. $41.2 \pm 19.0 \%$, for a standard reference material. The second method was almost the same as the first procedure, with the exception of the addition of ascorbic acid to the original sample before loading onto the TRU column to reduce Fe(III) interfering effects. $\mathrm{Pu}$ recoveries for the reference material were now increased to $84 \pm 6 \%$. In the third method, the first TRU column was removed. The UTEVA column was connected onto the top of TRU and in turn onto Sr column. Ascorbic acid was also used to reduce Fe(III) to Fe(II). The recoveries of Pu for reference material were now $56 \pm 8 \%$. As seen from the above results, relatively high $\mathrm{Pu}$ recoveries were obtained with the second separation process. The low recoveries of $\mathrm{Pu}$ in the first method were attributed to the competitive adsorption of Fe(III) onto the TRU column. With the removal of the first TRU column, matrix ingredients were proven to interfere severely with $\mathrm{Pu}$ isolation using the tandem UTEVA/TRU resins.

\subsection{High performance liquid chromatography}

High performance liquid chromatography (HPLC)-based methods can be regarded as an appealing alternative to low to medium pressure extraction chromatography for efficient separation of actinides in complex environmental samples. In this context, the work by Perna and co-workers [63] is worth mentioning. The authors described a procedure for the simultaneous separation and determination of lanthanides and actinides (viz., $\mathrm{Pu}, \mathrm{Np}, \mathrm{U}, \mathrm{Am}$ and $\mathrm{Cm}$ ) in sediment and spent 
nuclear fuel samples and based on the usage of a mixed-bed anionic/cationic chromatographic column (CS5A, Dionex). Different redox reagents in acid media were tested for converting Pu and $\mathrm{Np}$ into appropriate oxidation states. It was demonstrated that among $\mathrm{Fe}\left(\mathrm{NH}_{2} \mathrm{SO}_{3}\right)_{2}, \mathrm{NaNO}_{2}, \mathrm{Ag}_{2} \mathrm{O}$, $\mathrm{H}_{2} \mathrm{O}_{2}$ and $\mathrm{NH}_{2} \mathrm{OH} \cdot \mathrm{HCl}$, only $\mathrm{H}_{2} \mathrm{O}_{2}$ and $\mathrm{NaNO}_{2}$ were able to transform both $\mathrm{Pu}$ and $\mathrm{Np}$ in the samples into tetravalent forms. The retention times of $\mathrm{Np}$ and $\mathrm{Pu}$ were far from $\mathrm{U}$, whereby the potential interferences in samples with high uranium content are overcome. Detection limits of 0.25 $\mathrm{ng} \mathrm{mL} \mathrm{m}^{-1}$ and $0.45 \mathrm{ng} \mathrm{mL} \mathrm{m}^{-1}$ were obtained for lanthanides and actinides, respectively, using ICP-MS as a hyphenated detection system. Analytical precision was typical better than $5 \%$.

Truscott et al. [64] exploited high-performance chelation ion chromatography and detection by SF-ICP-MS, using polystyrene-divinylbenzene loaded with $0.1 \mathrm{mM}$ dipicolinic acid for the separation of actinides, including $\mathrm{Pu}$, in reference soil materials. In particular, ${ }^{238} \mathrm{U}$ was separated from ${ }^{239} \mathrm{Pu}$ to overcome the serious isobaric interference of ${ }^{238} \mathrm{U}^{1} \mathrm{H}^{+}$and tailing of ${ }^{238} \mathrm{U}$ on ${ }^{239} \mathrm{Pu}$. The studies on the oxidation states of the ions indicated that $\mathrm{Pu}(\mathrm{III})$ eluted near the solvent front, while $\mathrm{Pu}(\mathrm{IV})$ eluted much later and after U(VI). The detection limit for ${ }^{239} \mathrm{Pu}$ was $8 \mathrm{fg}$ for a $0.5 \mathrm{~mL}$ injection.

\subsection{Combination of different chemical separation methods}

Several researchers hyphenated various separation methods based on different chemical interactions aimed at improving the contamination factors for potential interfering elements on $\mathrm{Pu}$ determination as detailed in this section with selected representative examples. For instance, Donard et al. [58] proposed an analytical procedure for simultaneous determination of ${ }^{239} \mathrm{Pu},{ }^{240} \mathrm{Pu},{ }^{241} \mathrm{Pu}$ and ${ }^{242} \mathrm{Pu}$ in marine sediments using a combination of ion exchange chromatography and solvent extraction. Within this work, a Bio Rad AG $1 \times 8$ anion exchange resin was used in the primary separation stage to separate plutonium from sample matrix components, followed by solvent 
extraction with HTTA-xylene for further separation of $\mathrm{Pu}$ from interferences, such as Am but mostly U. A second anion exchange resin, Dowex $1 \times 8$, was used for final purification of $\mathrm{Pu}$. The analytical sequence is characterized by a reproducible yield of $42 \% \mathrm{Pu}$. Moreover, ${ }^{238} \mathrm{U}$ and ${ }^{241} \mathrm{Am}$ were both efficiently eliminated from the sample matrix. However, this procedure is somewhat time-consuming and labour intensive.

Jernström et al. [87] proposed a separation procedure for $\mathrm{Am}(\mathrm{III})$ and $\mathrm{Pu}(\mathrm{III})$ based on the coupling of TEVA extraction chromatography with cation exchange separation and mixed bed ion chromatography with quaternary ammonium and sulfonic acid exchange groups. $\mathrm{Pu}$ was firstly reduced to $\mathrm{Pu}(\mathrm{III})$ with ascorbic acid and $\mathrm{NH}_{2} \mathrm{OH} \cdot \mathrm{HCl}$. The separation of $\mathrm{Pu}(\mathrm{III})$ and $\mathrm{Am}(\mathrm{III})$ from lanthanides was performed with TEVA in ammonium thiocyanate-formic acid media, whereupon $\mathrm{Pu}(\mathrm{III})$ and $\mathrm{Am}(\mathrm{III})$ were pre-concentrated onto the ion-exchanger prior to the final multi-modal chromatographic separation.

Separation of $\mathrm{Pu}$ in soils and sediments was also accomplished using a combination of TRU extraction chromatography and anion exchange separation [48]. The anion exchange resin was used for further purification of $\mathrm{Pu}$ by removal of concomitantly eluted $\mathrm{U}$ from TRU resin. The recovery of Pu was typically close to $60 \%$, and decontamination factors for $\mathrm{U}$ and $\mathrm{Th}$ ranged from $10^{3}$ to $10^{4}$. In this context, the work by Kim et al. [57] exploiting the chelating Diphonix resin (Eichrom) to separate $\mathrm{U}, \mathrm{Pu}, \mathrm{Th}, \mathrm{Am}$ in environmental solids should also be mentioned. Actinides were eluted with $0.5 \mathrm{~mol} \mathrm{~L}^{-1} \mathrm{HEDPA}$, and the complexes in the eluate were decomposed by ozonation or usage of Fenton's reagent to release actinides. The separation of $\mathrm{Pu}$ from other elements (Am, U, Th) was performed on a TRU resin. Chemical recoveries of $85 \pm 5 \%$ for Pu were in this case obtained. Tavcar [55] developed a method for simultaneous separation of $\mathrm{Pu}$ and other radionuclides (Am, Np, Sr) in soil and sediments by the combination of anion exchange separation and extraction chromatography (TRU-Spec and Sr-Spec) with averaged chemical recoveries of $61 \% . \mathrm{NH}_{2} \mathrm{OH} \cdot \mathrm{HCl}$ and $\mathrm{NaNO}_{2}$ were 
employed to adjust $\mathrm{Pu}$ to $\mathrm{Pu}(\mathrm{IV})$ before loading on the anion exchanger for retention of $\mathrm{Pu}$ on the column as $\mathrm{Pu}\left(\mathrm{NO}_{3}\right)_{6}{ }^{2-}$. Separation of $\mathrm{Am}$ and $\mathrm{Sr}$ were performed using the TRU-Spec and Sr-Spec sorbents, respectively.

However, for samples of limited amount, the possibility of performing sequential analysis of a series of analytes (e.g., $\mathrm{Pu}, \mathrm{Np}, \mathrm{Am}$, Th, Po and $\mathrm{U}$ ) might be troublesome and demands for complicated designs of analytical procedures.

\subsection{Comparison of different chemical separation methods}

To date, only a few investigations have been devoted to the comparison of different chemical separation methods for $\mathrm{Pu}$ [88]. When comparing anion-exchange chromatography using e.g. Dowex $1 \times 8$ with extraction chromatography with TEVA resin, decontamination factors for $U$ are in the order of $10^{4}-10^{5}$ in both resins [88]. Chemical yields of $\mathrm{Pu}$ are within the interval of 54-99\% and 46-80\% for Dowex $1 \times 8$ and TEVA, respectively, depending on the operation conditions. However, the TEVA-extraction chromatographic method features lower acid consumption and gives rise to higher decontamination factors for Fe, $\mathrm{Mn}$ and $\mathrm{Ce}$.

As regards the comparison of chemical separation using either a single anion-exchanger (Dowex $1 \mathrm{X} 8$ ) or two extraction chromatographic columns (e.g., UTEVA and TRU) [82], Pu recoveries are normally better for ion exchange rather than extraction chromatographic separations (60\% vs $42 \%)$. This can be explained by the fact that one column is merely needed in ion exchange separation as compared to the extraction chromatographic method which usually requires the hyphenation of two extraction columns in series for accurate determinations.

\section{Source preparation}

Source preparation is a crucial step in radiochemical analysis. Generally sources for alpha spectrometric measurement of environmental samples are prepared by electro-deposition or 
electroplating $[47,48,54,62,67]$, or co-precipitation/micro-coprecipitation $[45,50,51,55,56$, 65,89]. Normally, $\alpha$-source of $\mathrm{Pu}$ is prepared by electro-deposition onto a stainless disk in an oxalate or sulphate medium. $\mathrm{Pu}$ is electrodeposited under a direct current $\left(300-400 \mathrm{~mA} \mathrm{~cm}^{-2}\right)$ for 2$4 \mathrm{~h}$. Several drops of ammonia are needed to be added to the cell before disconnecting the current in order to stabilize the Pu precipitate on the disk. Detection of $\mathrm{Pu}$ on disks after electrodeposition might be also performed by laser-ablation (LA)-ICP-MS [47]. For the source preparation using coprecipitation, fluorides $\left(\mathrm{NdF}_{3}, \mathrm{LaF}_{3}, \mathrm{CeF}_{3}\right)$ or iron hydroxides, as mentioned in the sample pretreatment step, have been employed. However, this method is not widely used any longer because of the potential losses of $\mathrm{Pu}$ and deteriorated spectra resolution during the alpha spectrometry measurement. In fact, Pilvio et al. [90] proved that co-precipitation cannot yield as high $\mathrm{Pu}$ recoveries as that of electrodeposition. If $\mathrm{Pu}$ is measured by mass spectrometric techniques the final solution is preferentially prepared in weak $\mathrm{HNO}_{3}$ (around $0.5 \mathrm{~mol} \mathrm{~L}-1$ ) medium.

\section{Detection of Pu isotopes}

There are two types of detection techniques for determination of $\mathrm{Pu}$ : (i) radiometric techniques including alpha-spectrometry, gamma/X-ray spectrometry and liquid scintillation counting (LSC), in which $\mathrm{Pu}$ is measured by its radioactive decay; and (ii) mass spectrometric techniques where the atoms of individual $\mathrm{Pu}$ isotopes are detected on basis of their respective masses [91].

\subsection{Radiometric method}

\subsubsection{Alpha-spectrometry}

Alpha spectrometry, as a traditional radiometric counting method, still plays an important role in the detection of $\mathrm{Pu}$ isotopes $[45,56,71]$. There are several types of detectors that can be used for the measurement of alpha emitting radionuclides, such as Frisch grid ionization chambers, proportional counters, plastic and liquid scintillation detectors and semiconductor detectors. 
Semiconductor alpha-spectrometry, using a surface barrier or ion-implanted silicon detector, has been widely adopted as a powerful technique because of simplicity of measurement, good spectra resolution and reasonable sensitivity for specific radionuclides, especially those with short half-lives [92]. The energy resolution given as full width at half peak maximum ranges normally from 15 to $55 \mathrm{keV}$. A typical detection limit by $\alpha$-spectrometry is in order of $10^{-4} \mathrm{~Bq}$, which corresponds to about 0.05 pg of ${ }^{239} \mathrm{Pu}$.

Although $\alpha$-spectrometry has the advantages of easy application and relatively low instrument expenses, this detection technique requires very long counting times (1-30 days), especially for the low level samples. Consequently, $\alpha$-spectrometric detection is not suitable for emergency situations, where analytical results should be obtained in a shorter time frame $(<1$ day). Further, the high charge and relatively low speed of alpha particles result in significant energy losses, even in very thin absorbers. Even though the energy losses in the source usually are not high enough to significantly lower the counting efficiency, the spectra becomes degraded with reduced resolution and increased peak overlapping. It is therefore imperative to completely separate $\mathrm{Pu}$ from all other elements in the sample matrix prior to alpha spectrometric detection.

Alpha spectrometry is incapable of distinguishing between ${ }^{239} \mathrm{Pu} /{ }^{240} \mathrm{Pu}$ and ${ }^{238} \mathrm{Pu} /{ }^{241} \mathrm{Am}$ because of the limited energy resolution of alpha detectors. High-resolution $\alpha$-spectrometry in combination with spectral deconvolution is a useful method in resolving the ${ }^{239} \mathrm{Pu}$ and ${ }^{240} \mathrm{Pu}$ isotopes, but it requires spectra with good counting statistics. In addition, $\alpha$-spectrometric detection of long-lived ${ }^{242} \mathrm{Pu}$ and ${ }^{244} \mathrm{Pu}$ isotopes in environmental samples cannot be accurately performed due to their ultra-trace concentrations and the low specific activity of these isotopes. It should be also borne in mind that ${ }^{241} \mathrm{Pu}$ as a beta emitter is not detectable by $\alpha$-spectrometry [91]. There are however still several advantages with alpha spectrometry as compared to alternative techniques. The radiometric technique is very robust and reliable with a near $100 \%$ functional up-time, which should be kept in 
mind when comparing with e.g. mass-spectrometry. Spectra are extremely simple, thereby minimising the risks of misinterpretation due to potential interfering peaks and presence of stable elements even though the preliminary chemical separation might be tedious and time-consuming for alpha spectrometry. There is no energy dependent efficiency and, compared to mass dependent efficiency in mass spectrometry, quantification is simply done by relating to the isotopic yield determinant. Detector background can be kept extremely low (less than 1 count per week in Puwindow) and be used for several years without deterioration of background or resolution. With respect to mass spectrometry one of the assets of alpha spectrometry is the possibility of detection of the relatively short-lived ${ }^{238} \mathrm{Pu}$.

\subsubsection{Liquid scintillation counting}

Liquid scintillation counting (LSC), because of its poor energy resolution, cannot compete with $\alpha$-spectrometry. Nowadays, with the improvement of LSC detectors, the discrimination between ${ }^{238} \mathrm{Pu}$ and ${ }^{239+240} \mathrm{Pu}$ is however feasible [93]. In contrast to $\alpha$-spectrometry, LSC has proved useful for the determination of the soft beta-emitter ${ }^{241} \mathrm{Pu}$ [93]. To this point, the stripping of ${ }^{241} \mathrm{Pu}$ out from the source is not needed, therefore, discs can be retrieved again for other purposes after LSC detection. But several problems have been described, e.g., if some contaminants (namely, Fe, Pt) are electroplated with $\mathrm{Pu}$, quenching effects, which decrease the detection efficiency, shift of alpha and beta spectra and mis-classification of alpha/beta events might occur. Furthermore, the LSC results depend on the chemical recovery given by $\alpha$-spectrometry and the complicated efficiency calibration of the instrument. 


\subsection{Mass spectrometry}

With conventional $\alpha$-spectrometry, ${ }^{238} \mathrm{Pu}$ and the combined intensity of ${ }^{239} \mathrm{Pu}$ and ${ }^{240} \mathrm{Pu}$ are usually measured while mass spectrometry facilitates the individual determination of ${ }^{239} \mathrm{Pu}$ and ${ }^{240} \mathrm{Pu}$. To identify the origin and total $\mathrm{Pu}$-concentration is actually of great advantage to be able to determine both the ${ }^{239} \mathrm{Pu} /{ }^{240} \mathrm{Pu}$ ratio as well as the ${ }^{238} \mathrm{Pu} /{ }^{239+240} \mathrm{Pu}$ ratio. The two techniques thus complement each other. Mass spectrometry is an atom counting technique which overcomes some specific problems of traditional radiometric methods. So far, a vast number of mass spectrometric methods, including inductively coupled plasma mass spectrometry (ICP-MS)[94] [46], thermal ionization mass spectrometry (TIMS), accelerator mass spectrometry (AMS) [95, 96], resonance ionization mass spectrometry (RIMS) [67], secondary ion mass spectrometry (SIMS), and glow discharge mass spectrometry (GDMS) have been introduced to improve the sensitivity and detection limit for determination of $\mathrm{Pu}$ isotopes, e.g., ${ }^{239} \mathrm{Pu},{ }^{240} \mathrm{Pu}$, in environmental samples as discussed in several review articles [91, 97-100]. However, as a consequence of the low concentration of $\mathrm{Pu}$ in the environment, the short half-life of ${ }^{238} \mathrm{Pu}$, and relatively high concentration of ${ }^{238} \mathrm{U}$, the isobaric interference of ${ }^{238} \mathrm{U}$ makes the unbiased detection of ${ }^{238} \mathrm{Pu}$ in environmental samples unattainable by mass spectrometry, even with decontamination factors as high as $10^{8}$ or better for $\mathrm{U}$.

\subsubsection{ICP-MS}

ICP-MS is becoming more and more important for the determination of trace and ultra-trace level of $\mathrm{Pu}$ in environmental samples with advantages of high sensitivity, short analytical times, relatively easy operation, and multi-isotopic detection including beta-emitters and straightforward quantification using aqueous standard solutions [101]. The first reported attempt to determine ${ }^{239} \mathrm{Pu}$ and ${ }^{240} \mathrm{Pu}$ in environmental samples by ICP-MS was done in 1989 by Kim et al. [75]. However, in 
order to reduce the sample consumption and consequently minimize instrumental radioactivity contamination and reduce waste generation, high efficiency micronebulization might be hyphenated with ICP-MS for precise and accurate determination of ultra trace radionuclides as well as their isotopic ratios. Various low-consumption nebulisers, such as the microconcentric nebulizer (MCN) [102, 103], the high efficiency nebulizer (HEN) [104-109], the direct injection nebulizer (DIN) [110-112], oscillating capillary nebulizer (OCN) $[113,114]$ and direct injection high efficiency nebulizer (DIHEN) [115-118] have been applied as effective sample introduction techniques in ICP spectrometers to increase introduction efficiency of analytes. The analytical characteristics of DIHEN for inductively coupled plasma quadrupole mass spectrometric (ICP-QMS) determination of trace level of long-lived radionuclides $\left({ }^{226} \mathrm{Ra},{ }^{230} \mathrm{Th},{ }^{237} \mathrm{~Np},{ }^{239} \mathrm{Pu}\right.$ and $\left.{ }^{241} \mathrm{Am}\right)$ have been examined by Becker and co-workers and compared with those of cross-flow and MicroMist microconcentric nebulisers [116]. It was proven that DIHEN-ICPMS is the most suitable coupling for the sensitive and precise determination of long-lived radionuclides within the $\mathrm{n} \mathrm{L}^{-1}$ range

Over the past decades, several types of ICP-MS including sector field (or high resolution) ICPMS (SF-ICP- MS) [45, 54, 58, 59, 64, 72, 89] and laser-ablation ICP-MS (LA-ICP-MS) [45, 47, 119] have been successfully applied to the determination of $\mathrm{Pu}$ in various matrices. SF-ICP-MS is one of the most appropriate detection instruments for isotopic analysis of $\mathrm{Pu}$. As compared with ICP-QMS, SF-ICP-MS features improved resolution, thereby facilitating the minimization of spectral interferences, and high sensitivity at a low resolution mode. Stürup et al [59], for example, employed SF-ICP-MS for the determination of $\mathrm{Pu}$ isotopes and isotopes ratios in sediment and seawater. Detection limits of 5,1 , and $1 \mathrm{fg} \mathrm{mL}^{-1}\left(11.5 \mu \mathrm{Bq} \mathrm{mL}^{-1}, 8.4 \mu \mathrm{Bq} \mathrm{mL}^{-1}\right.$ and $\left.3.8 \mathrm{mBq} \mathrm{mL}^{-1}\right)$ were obtained for ${ }^{239} \mathrm{Pu},{ }^{240} \mathrm{Pu}$ and ${ }^{241} \mathrm{Pu}$, respectively. Donard et al [58] applied SF-ICP-MS for simultaneous detection of ${ }^{239} \mathrm{Pu},{ }^{240} \mathrm{Pu},{ }^{241} \mathrm{Pu}$ and ${ }^{242} \mathrm{Pu}$ in sediments. The measurement was carried out at a low resolution mode $(\mathrm{m} / \Delta \mathrm{m}=400)$, and two different detection procedures were used. In the 
first procedure, ten masses (from 235 to 244) were measured in order to screen the presence of ${ }^{243} \mathrm{Am}$ and ${ }^{236} \mathrm{U}$ as well as the signal intensity of ${ }^{238} \mathrm{U}$ for estimating the interference of ${ }^{238} \mathrm{U}$ in the detection of ${ }^{239} \mathrm{Pu}$. In the second procedure, five masses $(239,240,241,242$ and 244) were measured to quantify the activity of ${ }^{239} \mathrm{Pu},{ }^{240} \mathrm{Pu},{ }^{241} \mathrm{Pu},{ }^{242} \mathrm{Pu}$ as well as the tracer ${ }^{244} \mathrm{Pu}$. Varga et al [54] used SF-ICP-MS for monitoring ${ }^{239} \mathrm{Pu},{ }^{240} \mathrm{Pu}$ and ${ }^{241} \mathrm{Pu}$ in soils and sediments. The instrument was equipped with a single electron multiplier and the measurement was carried out at a low resolution mode $(\mathrm{m} / \Delta \mathrm{m}=300)$. The possible hydride and oxide interferences (e.g., ${ }^{238} \mathrm{U}^{1} \mathrm{H}^{+}$or ${ }^{207} \mathrm{~Pb}^{16} \mathrm{O}_{2}^{+}$) were reduced using a desolvation sample introduction system. For further minimization of hydride formation in ICP-MS, sample desolvation was combined with $\mathrm{Ar}-\mathrm{N}_{2}$ mixed gas plasma. Although the addition of nitrogen might increase nitrogen containing polyatomic interferences, the $\mathrm{UH}^{+} / \mathrm{U}^{+}$ratio was lower than $10^{-5}$. Detection limits of $34 \mu \mathrm{Bq} \cdot \mathrm{g}^{-1}, 80 \mu \mathrm{Bq} \cdot \mathrm{g}^{-1}$, and $54 \mathrm{mBq} \cdot \mathrm{g}^{-1}$ for ${ }^{239} \mathrm{Pu},{ }^{240} \mathrm{Pu}$ and ${ }^{241} \mathrm{Pu}$, respectively, were achieved. The same authors later reported improved detection limits of $21 \mu \mathrm{Bq} \cdot \mathrm{g}^{-1}, 14 \mu \mathrm{Bq} \cdot \mathrm{g}^{-1}$, and $11.9 \mathrm{mBq} \cdot \mathrm{g}^{-1}$ for ${ }^{239} \mathrm{Pu},{ }^{240} \mathrm{Pu}$ and ${ }^{241} \mathrm{Pu}$, respectively, by using similar operation conditions for SF-ICP-MS but without application of Ar- $\mathrm{N}_{2}$ mixed gas plasma [71]. However, the ${ }^{241} \mathrm{Pu}$ results had relatively large uncertainty if the intensity of signals is rather low. It is also worth to mention in this context the contribution of Schaumöffel et al [72] because of the development of an analytical procedure based on nano-volume flow injection and SF-ICP-MS for the determination of $\mathrm{Pu}$ in tap water. Solution introduction into SF-ICP-MS was performed using a nano-volume injector with a microflow total consumption nebulizer. This nebulizer featured efficient sample introduction and analyte ionization, leading to improved method sensitivity. An absolute detection limit of $150 \mathrm{fg}{ }^{242} \mathrm{Pu}$ using a 54-nL injection loop was reported.

LA-ICP-MS has the advantage of direct sampling of solid material surface without dissolution neither dilution of samples. Boulyga et al. [47] combined LA-ICP-MS with isotope dilution for the determination of $\mathrm{Pu}$ and $\mathrm{Am}$ in mosses after electrodeposition. Although the use of laser ablation 
did not eliminate $\mathrm{UH}^{+}$completely, the interfering effects were reduced significantly as a result of the generation of a dry aerosol [45, 119]. A detection limit of $0.3 \mathrm{pg} \mathrm{g}^{-1}$ for $\mathrm{Pu}$ isotopes was achieved by the combination of a modified laser ablation system providing high ablation rates and double-focusing SF-ICP-MS. Experimental results were in satisfactory agreement with certified values obtained with both $\alpha$-spectrometry and ICP-MS after sample pre-treatment and chemical separation. However, inhomogeneous distribution of the analyte in the sample, in particular the presence of "hot" particles, might affect the precision and accuracy of the analysis.

Unfortunately, the accurate determination of Pu by ICP-MS is hampered by both spectral and non-spectral interferences. The major problem with spectral interferences is caused by the occurrence of isobars and polyatomic molecules in the plasma, of which the most important are ${ }^{238} \mathrm{U}^{238}{ }^{23 \mathrm{UH}^{+}},{ }^{238} \mathrm{UH}_{2}{ }^{+}$and ${ }^{241} \mathrm{Am}$ which overlap with the measurement of ${ }^{238} \mathrm{Pu},{ }^{239} \mathrm{Pu},{ }^{240} \mathrm{Pu}$ and ${ }^{241} \mathrm{Pu}$ isotopes, respectively. Thus, ICP-MS detection requires good separation of ${ }^{238} \mathrm{U}$ prior to ${ }^{239} \mathrm{Pu}$ determination and elimination of polyatomic chlorides and oxides. The tailing effect (low abundance sensitivity) from the high signal of ${ }^{238} \mathrm{U}$ is another drawback which limits the actual application of SF-ICP-MS. Moreover, the extremely low concentrations of $\mathrm{Pu}$ in the environment and high salt and organic matter content often lead to signal suppression, and consequently, to poor method accuracy.

\subsubsection{AMS}

AMS is among the most sensitive detection techniques for many long-lived radionuclides. Detection limits for ${ }^{239} \mathrm{Pu}$ are for example down to $10^{6}$ atoms. Moreover, AMS features much lower matrix interfering effects compared to ICP-MS. For Pu isotopes, the main advantage of AMS with respect to conventional MS (TIMS or ICP-MS) is the complete destruction of molecular isobars (e.g., ${ }^{238} \mathrm{UH}^{+}$for ${ }^{239} \mathrm{Pu}$ ) by stripping to highly positive charge states in the terminal of the tandem 
accelerator. Furthermore the abundance sensitivity is the best among the different massspectrometry techniques.

Fifield et al. [120] reported the first quantitative application of AMS to the determination of $\mathrm{Pu}$ isotopes in environmental samples at levels below those attainable with existing techniques (e.g., $\alpha$ spectrometry and ICP-MS). In addition, determination of the ${ }^{240} \mathrm{Pu} /{ }^{239} \mathrm{Pu}$ ratio is readily accomplishable. McAninch et al. [96] demonstrated that the installation of a heavy element spectrometer including a $45^{\circ}$ cylindrical electrostatic analyzer is central to improve abundance

sensitivity and minimize ${ }^{238} \mathrm{U}$ interference, hereby background levels are reduced to below $1 \times 10^{6}$ atoms per sample at masses 237, 239, 240 and 241 while allowing simplification of the sample preparation chemistry. Hrecek et al. [56] determined $\mathrm{Pu}$ isotopes in nuclear weapons test sites and stressed that the AMS and $\alpha$-spectrometric results were in good agreement. With the increasing number of AMS facilities, a large number of AMS applications have been devoted to the determination of $\mathrm{Pu}$ isotopes in environmental samples.

\subsubsection{TIMS and RIMS}

To some extent, TIMS has better sensitivity and precision for isotope ratio measurements than ICP-MS. TIMS with multiple ion collectors is generally the method of choice for isotope ratio measurements with high precision (down to $0.002 \%$ ). Efurd et al. [121] conducted the analysis of soils and sediments using TIMS to determine the ratio of ${ }^{240} \mathrm{Pu} /{ }^{239} \mathrm{Pu}$. The spectrometer was equipped with a sample turret that held five surface ionization diffusion controlled filaments. Problems with spectral interferences of uranium in TIMS are less severe inasmuch as uranium and $\mathrm{Pu}$ have different ionization potentials and thus are emitted from the filament at different temperatures. In addition, the introduction of dry samples reduces the formation of $\mathrm{UH}^{+}$species to a large extent. TIMS requires, however, an expensive instrument and robust separation to ensure the 
constant ionization of the analyte. This technique is also very time consuming, labour intensive and cannot be used for on-line detection because pre-concentration of Pu has to be done manually on a filament. Further, the mass-fractionation effect requires the determination of accurately known isotope ratio standards in order to be gain benefit from the high reproducibility of the instrument.

RIMS is well suited for trace analysis of long-lived $\mathrm{Pu}$ isotopes. In RIMS, the evaporated liquid samples on a filament are atomized by an atomic beam source. One or, in most cases, more lasers are tuned precisely to the wavelength required for the excitation and ionization of evaporated atoms in order to obtain a highly selective resonance ionization of the element of interest. RIMS is highly sensitive because of the large atomic cross-section on the excitation-ionization process and the good detection efficiency. A detection limit of $10^{6}$ to $10^{7} \mathrm{Pu}$ atoms has been achieved for the overall isotopes, regardless of their half-lives and decay modes [67]. The high sensitivity of RIMS fosters the exploitation of a simplified procedure for the chemical preparation of samples as compared to the requirements of thin sources for $\alpha$-spectrometry. Gruning et al. [122] developed a pulsed RIMS apparatus with a neodymium-doped yttrium aluminium pumped titanium-sapphire laser system for detection of $\mathrm{Pu}$ isotopes. A detection limit of $2 \times 10^{6}$ atoms was achieved. However, no commercial RIMS instruments are yet available.

\subsection{Comparison of detection techniques}

Table 9 summarizes the figures of merit of different detection techniques for Pu isotopes. For the measurement of ${ }^{238} \mathrm{Pu}$ and ${ }^{239+240} \mathrm{Pu}, \alpha$-spectrometry is still a powerful technique because of simplicity of measurement, good resolution and reasonable sensitivity. In fact, $\alpha$-spectrometry is the only method suitable for detection of ${ }^{238} \mathrm{Pu}$. However, long counting times for low activity samples are needed and separation of ${ }^{239} \mathrm{Pu}$ and ${ }^{240} \mathrm{Pu}$ is difficult. Detection of ${ }^{241} \mathrm{Pu}$ by LSC features several advantages including fast analysis times and without need for stripping $\mathrm{Pu}$ out of the disc after 
determination of alpha emitters. Of the mass spectrometric methods, ICP-MS is commonly selected for simultaneous measurement of ${ }^{239} \mathrm{Pu},{ }^{240} \mathrm{Pu}$, and sometimes ${ }^{241} \mathrm{Pu}$, in environmental samples. TIMS and AMS might provide improved sensitivity yet the analyses are costly. As to TIMS, the separation procedure is so critical that a preliminary sorbent extraction/chromatographic method should be repeated at least twice to separate $\mathrm{Pu}$ from matrix constituents. But the detection limit and precision of isotopic measurements are better in TIMS. AMS operation is more complex and a well experienced team is required. Yet, this detection technique is earning popularity because of instrumental developments. RIMS offers a number of assets as compared to other mass spectrometric techniques, including minimization of isobaric interferences, good detection limits, high selectivity and short detection times. However, the application of RIMS is still limited because a limited number of facilities are at disposal and the instruments are not currently commercially available. It should also be kept in mind that although advanced mass spectrometric techniques might be used for sensitive determination of plutonium isotopes relevant issues regarding plutonium behaviour and distribution in the environment could be tackled using simpler radiometric methods.

\section{Automated determination of Pu isotopes}

\subsection{Principles of flow injection and sequential injection}

Radiometric and MS determination of $\mathrm{Pu}$ in environmental samples requires as explained earlier some degree of separation of $\mathrm{Pu}$ from stable matrix and interfering radionuclides in order to obtain reliable analytical data. Therefore, radionuclide pre-concentration and separation methods remain to be an important and often critical part of the overall radioanalytical protocol. Many of the current analytical procedures for separating and determining $\mathrm{Pu}$ in complex samples are several decades old. Although sensitive, precise, and accurate, these classical procedures can often be timeconsuming and labour intensive, based on use of corrosive or toxic chemicals, and leading to the 
generation of substantial amounts of secondary hazardous liquid and solid wastes. The main reasons for changing previous protocols are devoted to the need of their adaptation to mass spectrometric detection, which is in continuous growing, and also the expedition of the overall analysis procedure. The mechanization or automation of analytical systems for separation and determination of $\mathrm{Pu}$ should be regarded as an attractive avenue to accelerate support operations and decrease expenses in the characterization of wastes and monitoring of the environment as well. Flow injection (FI) analysis [33, 35-37], and its second generation so-called sequential injection (SI) analysis[39], represent attractive tools to automate various separation methods, such as solvent extraction and column separation prior to analyte (e.g., radionuclide) detection [41, 42, 44].

Flow injection analysis has found wide application as a non-chromatographic technique for automated quantitative analysis [125]. Exploiting chemical and/or physical kinetic control of the analytical method, the selectivity and speed of the analysis are often superior to those of conventional batchwise equilibrium counterparts $[33,35]$. The precise control of physical variables in an entirely enclosed system has been used to design powerful analytical systems for many applications, including environmental trace analysis [33-37]. Conditions that would normally foul or deteriorate the detector can be automatically and systematically overcome by using FI approaches. A schematic illustration of a three-line flow injection system is presented in Fig. 3(a) and consists of a peristaltic pump (PP) that is used to propel the carrier stream through a narrow tube (0.3-0.8 mm i.d.); an injection device that introduces a minute, well-defined volume of sample solution (typically $\geq 25 \mu \mathrm{L}$ ) into the carrier stream in a very reproducible manner; reaction coil(s) (R1 and R2) in which the sample zone disperses and reacts with the reagent(s), forming species that are detected by a flow-through detector (D); which records the transient FI readouts.

As a result of growing environmental demands for reduced consumption of sample and reagent solutions, the first generation of FI, which utilizes continuous pumping of carrier and reagent(s), 
was in 1990 supplemented by SI [126]. Sequential injection is based on using programmable, bidirectional discontinuous flow as precisely coordinated and controlled by a computer. The SI analyzers can be configured to perform most operations of conventional FI, with no or minimal physical reconfigurations of the manifold when aiming at multiparametric assays [35, 39]. A sketch of a typical SI-manifold is reproduced in Fig. 3(b). The core of the system is a multi-position selection valve (here shown as a 6-port valve), furnished with a central rotary communication channel (CC) that can be made to address each of the peripheral ports (1-6), and a central communication line (CL) which, via a holding coil (HC), is connected to a syringe pump operating as the liquid driver. By directing the central communication channel to the individual ports, welldefined and precisely metered sample and reagent zones (typically 5-25 $\mu \mathrm{L}$ ) are initially aspirated sequentially into the holding coil where they are stacked one after the other. The holding coil prevents the aspirated solutions from entering into the pump. Afterwards, the selection valve is switched to the outlet port (here position 5), and the segments are propelled forward towards the detector, undergoing on their way dispersion and thereby partial mixing with each other, and hence promoting chemical reaction, the result of which is monitored by the detector.

The main assets of automated SI methods in comparison to the traditional separation methods for radionuclides [127] include: (i) improved practitioner safety because manual operations are scarcely needed and the separation is performed in a fully enclosed system; (ii) rapid execution of sample processing steps; (iii) on-line hyphenation to the detector, e.g., ICP-MS or LSC; (iv) decreased reagent consumption and radioactive waste generation; (v) less sample cross contamination by appropriate execution of clean-up steps; and (vi) high recovery, good selectivity and acceptable reproducibility. The instrumental simplicity, flexibility, robustness, minimal operational maintenance and ease with which hydrodynamic variables can be controlled in SI, have turned it 
into a very appealing choice within both research and to some extent to industrial laboratories for automation of chemical assays.

\subsection{FI/SI-based separations for on-line determination of Pu}

FI/SI assemblies have been over the past few years devised for on-line analysis of environmental samples contaminated with $\mathrm{Pu}$. Relevant analytical procedures for automatic determination of $\mathrm{Pu}$ in different environmental matrices are summarized in Table 10 and described in the following subsections. Based on the type of the resins utilized in the separation procedure, on-line FI/SI column separation systems can be divided into two categories, i.e. those involving extraction chromatography and those based on the use of ion exchangers.

\subsubsection{FI/SI-based extraction chromatographic separations}

\subsubsection{Single column}

The first reported application of FI/SI for determination of Pu was developed by Egorov and Grate in 1998 [128] based on a methodology introduced by Horwitz and co-workers [83]. The developed FI procedure focused on the separation of $\mathrm{Am}$ and $\mathrm{Pu}$ from each other and from interfering matrix constituents (e.g. fission products) using the actinide-specific TRU-resin column. The separation of $\mathrm{Am}$ and $\mathrm{Pu}$ was performed by sample uptake in a $1 \mathrm{~mol} \mathrm{~L}^{-1} \mathrm{HNO}_{3}$ medium, in which $\mathrm{Pu}$ was adjusted to $\mathrm{Pu}(\mathrm{III})$, wash of the column with $1 \mathrm{~mol} \mathrm{~L}^{-1} \mathrm{HNO}_{3}$ to remove matrix and interfering radionuclides, adjustment of $\mathrm{Pu}$ valence to $\mathrm{Pu}(\mathrm{IV})$ with $0.5 \mathrm{~mol} \mathrm{~L}^{-1} \mathrm{NaNO}_{2}-2 \mathrm{~mol} \mathrm{~L}^{-1}$ $\mathrm{HNO}_{3}$, elution of $\mathrm{Am}(\mathrm{III})$ with $4 \mathrm{~mol} \mathrm{~L}^{-1} \mathrm{HCl}$, and then selective recovery of $\mathrm{Pu}$ by reduction to Pu(III) with $0.02 \mathrm{~mol} \mathrm{~L}^{-1} \mathrm{TiCl}_{3}-4 \mathrm{~mol} \mathrm{~L}^{-1} \mathrm{HCl}$ following a similar analytical method as described above in section 3.3. Radiometric detection was performed on-line using a flow-through liquid scintillation detector. Fajardo et al. [129] reported an automated system for the separation of Pu and 
Am using this separation procedure and multisyringe flow injection analysis- multipumping flow sytem. Grate et al. [130] further investigated and optimized the above-mentioned FI system for separation of $\mathrm{Am}$ and $\mathrm{Pu}$. Selective $\mathrm{Pu}$ elution using different reducing agents was studied and the effects of column size, and flow rate were discussed as well. It was found that $0.1 \mathrm{~mol} \mathrm{~L}^{-1}$ hydroquinone, $0.2 \mathrm{~mol} \mathrm{~L}^{-1}$ semicarbazide, $0.2 \mathrm{~mol} \mathrm{~L}^{-1}$ ascorbic acid, $0.05 \mathrm{~mol} \mathrm{~L}^{-1} \mathrm{SnCl}_{2}$ and $0.2 \mathrm{~mol}$ $\mathrm{L}^{-1} \mathrm{NaI}$ in $4 \mathrm{~mol} \mathrm{~L}^{-1} \mathrm{HCl}$ solution proceeded slowly and resulted in wide and severely tailed elution profiles. On the other hand, reduction with $0.05 \mathrm{~mol} \mathrm{~L}^{-1}\left(\mathrm{NH}_{4}\right)_{2} \mathrm{Fe}\left(\mathrm{SO}_{4}\right)_{2}-0.1 \mathrm{~mol} \mathrm{~L}^{-1}$ ascorbic acid and $0.02 \mathrm{~mol} \mathrm{~L}^{-1} \mathrm{TiCl}_{3}$ gave sharp and complete $\mathrm{Pu}$ elution without significant tailing. Experimental results revealed that the on-line $\mathrm{TiCl}_{3}$-based elution performed more reliably as compared to $\left(\mathrm{NH}_{4}\right)_{2} \mathrm{Fe}\left(\mathrm{SO}_{4}\right)_{2}$-ascorbic acid elution when the separation was carried out on larger columns. The results of the flow-though extraction chromatographic method using standard $\mathrm{Pu}$ and Am solutions indicate that $\mathrm{Am}-\mathrm{Pu}$ separation can be performed rapidly $(<10 \mathrm{~min})$ and recoveries of $\mathrm{Pu}$ and $\mathrm{Am}$ were quantitative (around 100\%). Grate et al. [131] also published an SI separation system for determination of $\mathrm{Pu}, \mathrm{Am}, \mathrm{Cm}$ and $\mathrm{Th}$ from nuclear waste samples using TRU-based extraction chromatography. On-line LSC was used to detect eluted species during method development, and fraction collection and $\alpha$-spectroscopy were used for quantification. Selective separation of $\mathrm{Pu}$ was achieved via on-column redox reactions. In this approach, all of the $\mathrm{Pu}$ was adjusted in a single oxidation state of $\mathrm{Pu}(\mathrm{III})$ with the addition of solid sulfamic acid and ascorbic acid before sample loading. To perform on-column $\mathrm{Pu}$ oxidation, an oxidizing agent $\left(\mathrm{NaNO}_{2}\right)$ was included in the column washing step, followed by elution of trivalent actinides with 4 mol L ${ }^{-1} \mathrm{HCl}$. Pu(VI) retained on the column is then reduced and eluted as $\mathrm{Pu}$ (III) using Fe(II)-sulfamate/ ascorbic acid as the eluent. Experimental results in three types of aged nuclear waste reference materials including aged irradiated nuclear fuel, tank waste supernatant and vitrified nuclear waste were in good agreement with the certified values. The recovery of $\mathrm{Pu}$ was $85 \%$. Using a similar manifold, the 
same group [132] combined SI with extraction chromatography on TRU resin and on-line ICP-MS detection for separation and determination of $\mathrm{Am}, \mathrm{Pu}$ and $\mathrm{Np}$ in dissolved vitrified nuclear wastes. Reductive sample treatment procedures were used to adjust $\mathrm{Pu}$ and $\mathrm{Np}$ redox states prior to analysis. Uranium decontamination factors ranged from $4.9 \times 10^{3}$ to $3.0 \times 10^{5}$ when using Fe-ascorbic acid and Fe(II) sulfamate-based sample treatment, respectively. An SI manifold furnished with an extraction chromatographic column prior to the detection instrument is illustrated in Fig 4.

Truscott et al. [124] developed an automated extraction chromatographic method using TRU resin in hyphenation with SF-ICP-MS for determination of $\mathrm{Pu}, \mathrm{Np}, \mathrm{Th}, \mathrm{U}$ and $\mathrm{Am}$ in reference materials. Efficient elution of analytes from the mini column was proven feasible with small eluent volumes, thereby facilitating the on-line connection of the flow system to ICP-MS. The procedure however rendered slightly low recoveries for Pu in NIST 4353 (Rock Flats Soil), that is, $2423 \pm 137$ $\mathrm{fg} \mathrm{g}^{-1}$ versus the certified $3307 \pm 248 \mathrm{fg} \mathrm{g}^{-1}$. A simultaneous analytical method for determination of ${ }^{237} \mathrm{~Np},{ }^{239} \mathrm{Pu}$ and ${ }^{240} \mathrm{Pu}$ in soils was proposed by Kim and coworkers [133] using an SI system with TEVA-based sample separation coupled to SF-ICP-MS detection. TEVA resin maintained its reusability for up to nine replicates, giving rise to high and consistent chemical recoveries (>90\%), good selectivity for $\mathrm{Pu}$ and low analyte carryover. With the exception of the preparation process required prior to sample loading, the overall chemical purification sequence and detection by SFICP-MS could be completed within 1 hour. Recently, Epov et al [134] developed a rapid on-line analytical method for the determination of $\mathrm{Pu}$ isotopes in soils and sediments. Flow injection chromatography using TEVA was exploited to separate and pre-concentrate $\mathrm{Pu}$ from other matrix constituents using ascorbic acid as a redox reagent. Pu was finally eluted with $0.02 \mathrm{~mol} \mathrm{~L}^{-1} \mathrm{HCl}$ and detected by ICP-QMS using an APEX desolvation unit with a Mira Mist nebulizer to minimize clogging and hydride interferences. The total time for the on-line analysis of a single sample was about $23 \mathrm{~min}$. 


\subsubsection{Combination of extraction columns}

Kim and coworkers [135] reported an on-line separation method for pre-concentration of $\mathrm{Pu}$ and elimination of ${ }^{238} \mathrm{U}$ with the use of isotope dilution- SF-ICP-MS for determination of ultra low level concentrations of ${ }^{239} \mathrm{Pu}$ and ${ }^{240} \mathrm{Pu}$ in small amounts of soil and sediment. Two mini columns (4.6 $\mathrm{mm}$ id $\times 30 \mathrm{~mm}$ long PEEK column and $3.0 \mathrm{~mm}$ id $\times 25 \mathrm{~mm}$ long borosilicate column) were assembled in series in the flow manifold. The first column packed with $\mathrm{Sr}$ resin was used to remove several interfering elements, including ${ }^{238} \mathrm{U}$, either quantitatively or partially from the sample matrix. $\mathrm{Pu}$ was retained strongly on the Sr-resin in $4 \mathrm{~mol} \mathrm{~L}^{-1} \mathrm{HNO}_{3}$ and eluted with $<1 \mathrm{~mol} \mathrm{~L}^{-1} \mathrm{HNO}_{3}$, whereas ${ }^{238} \mathrm{U}$ was retained very weakly in $<4 \mathrm{~mol} \mathrm{~L}^{-1} \mathrm{HNO}_{3}$. The second column packed with TEVA resin was used for further purification of $\mathrm{Pu}$ from other elements and decreasing the final eluate volume without increasing the concentration of concomitant ${ }^{238} \mathrm{U}$. The eluate of $\mathrm{Sr}$ resin containing $\mathrm{Pu}$ in $0.8 \mathrm{~mol} \mathrm{~L}-1 \mathrm{HNO}_{3}$ could be loaded onto TEVA resin directly because $\mathrm{Pu}$ was retained strongly in $\geq 0.8$ mol L ${ }^{-1} \mathrm{HNO}_{3}$, whereas ${ }^{238} \mathrm{U}$ was retained weakly in $\mathrm{HNO}_{3}$ on the TEVA resin. Pu recoveries were over $70 \%$ and the final decontamination factors for ${ }^{238} \mathrm{U}$ were in the order of $10^{4}-10^{5}$. It was reported that the separation and detection of $\mathrm{Pu}$ in $1 \mathrm{~g}$ of soil or sediment could be achieved within about $5 \mathrm{~h}$. The results obtained in this work were in good agreement with certified values with deviations of $<10 \%$ The detection limits for ${ }^{239} \mathrm{Pu},{ }^{240} \mathrm{Pu},{ }^{242} \mathrm{Pu}$ in a $2.4 \mathrm{~mL}$ final solution were $9.2 \mu \mathrm{Bq}, 25 \mu \mathrm{Bq}, 0.87 \mu \mathrm{Bq}$, respectively. The same authors proposed a modification of the above FI system to make it suited for determination of $\mathrm{Pu}$ in seawater [136]. The chemical purification and pre-concentration of $\mathrm{Pu}$ isotopes were still performed by the application of two mini-columns $(6.6 \mathrm{~mm}$ i.d. $\times 25 \mathrm{~mm}$ long borosilicate column and $1.8 \mathrm{~mm}$ i.d. $\times 20 \mathrm{~mm}$ long PEEK column) of extraction resins, Sr and TEVA, respectively. But contrary to the previous study, the first column was enlarged to eliminate the large amount of $\mathrm{Pb}$ in seawater while the dead volume of 
the second column was 3-fold shortened to obtain narrow and sharp elution profiles. With this configuration, the detection limits for ${ }^{239} \mathrm{Pu}$ and ${ }^{240} \mathrm{Pu}$ in $650 \mu \mathrm{L}$ final eluate were $1.5 \mu \mathrm{Bq} \mathrm{mL}^{-1}$ and 1.6 $\mu \mathrm{Bq} \mathrm{mL} \mathrm{m}^{-1}$, respectively. The separation and measurement of $\mathrm{Pu}$ in $5 \mathrm{~L}$ seawater can be achieved within $4 \mathrm{~h}$. The recoveries were ca. $58 \%$ and ten multiple analysis of certified reference seawater (IAEA-381) could be done without replacement of resins. The ranges of decontamination factors for $\mathrm{U}$ and $\mathrm{Pb}$ in $5 \mathrm{~L}$ of seawater were 1.2-2.4 $\times 10^{6}$ and 1.6-3.8 $\times 10^{4}$, respectively.

\subsubsection{FI/SI-based ion exchange chromatographic separations}

Kim and co-workers demonstrated the applicability of flow-through anion-exchange resins (e.g., Dowex $1 \times 8$ ) for the separation and concentration of $\mathrm{Pu}$ in soils [137]. In this method, $\mathrm{NaNO}_{2}$ was used to adjust the $\mathrm{Pu}$ valence to $\mathrm{Pu}(\mathrm{IV})$ prior to sample loading. A series of solutions, viz., $8 \mathrm{~mol} \mathrm{\textrm {L } ^ { - 1 }}$ $\mathrm{HNO}_{3}, 10 \mathrm{~mol} \mathrm{~L}^{-1} \mathrm{HCl}$ and $0.1 \mathrm{~mol} \mathrm{~L}^{-1} \mathrm{NH}_{4} \mathrm{I}+9 \mathrm{~mol} \mathrm{~L}^{-1} \mathrm{HCl}$, were consecutively delivered to the anion-exchanger following sample loading for removal of uranium, americium and thorium, and elution of $\mathrm{Pu}$, respectively. The total time for one run separation process was $5.2 \mathrm{~h}$ and two samples could be analyzed simultaneously within the designed flow system. The chemical recovery of $\mathrm{Pu}$ in the automated system ranged from $85 \%$ to $96 \%$ with a relatively low standard deviation of $8 \%$.

A protocol for the determination of Pu in apple leaves (NIST 1515) has been reported by Epov et al. [138]. The method consisted of microwave assisted digestion, flow injection on-line preconcentration and matrix separation, and sample desolvation prior to introduction into ICP-dynamic reaction cell-MS. To investigate the separation of $\mathrm{Pu}$ from $\mathrm{Fe}$ and rare earth elements, three kinds of resins, i.e., one extraction resin (TRU) and two anion exchange resins (AG 1-×8 and AG MP-1M) were investigated and compared with each other. It was found that both Fe and rare earth elements were not retained on $\mathrm{AG} 1 \times 8$ and $\mathrm{AG}$ MP-1M resins in $\mathrm{HNO}_{3}$ medium, but sorbed on the TRU extraction resin and competed with $\mathrm{Pu}$ for sorption. Compared with TRU and AG $1 \times 8$ resins, AG 
MP-1M resin performed better affinity for $\mathrm{Pu}$ and thus AG MP-1M was recommended for Pu preconcentration and sample clean-up in plant tissues.

On-line coupling of ion-exchange separation with ICP-MS is however not a simple task because of the relatively larger volume of eluent required as compared to extraction chromatography and the incompatibility of common $\mathrm{Pu}$ eluents, typically a mixture solution of $\mathrm{HCl}$ with $\mathrm{HI}$ or NH4I, with the detector. Therefore, FI/SI based ion exchange chromatography is frequently performed in an off-line detection fashion, which on the other hand, foster the automated separation of several samples at a time as described in the literature [137].

\section{Conclusions and outlook}

In this article, analytical methods recently reported in the literature for pre-treatment, purification and determination of $\mathrm{Pu}$ isotopes in environmental matrices are comprehensively reviewed and critically compared. As to processing of solid samples, drying, ashing and acid or alkali digestion and co-precipitation are routine procedures, yet filtration, evaporation and coprecipitation are most frequently used for liquid samples. Valence adjustment is a crucial step to warrant high recoveries in sorbent extraction procedures. Ion exchange and extraction chromatography are the most widely utilized methods both in a manual or automatic fashion as discussed in the bulk text. Ion exchange methods are simple and might be performed unattended but offer limited selectivity. On the other hand, extraction chromatographic procedures are flexible, highly selective but with moderate sensitivity. Up to date, $\alpha$-spectrometry and ICP-MS are the common detection methods for $\mathrm{Pu}$ isotopes. Radiometric measurements using $\alpha$-spectrometers are easy and cost-effective, but relative high analyte concentration and long measurement times are needed for accurate quantification. Detection of ${ }^{238} \mathrm{Pu}$ and ${ }^{239+240} \mathrm{Pu}$ is feasible, but not ${ }^{239} \mathrm{Pu}$ and

${ }^{240} \mathrm{Pu}$ individually. On the contrary, ICP-MS is fast, highly sensitive and capable of providing the 
individual concentrations of ${ }^{239} \mathrm{Pu}$ and ${ }^{240} \mathrm{Pu}$, yet determination of ${ }^{238} \mathrm{Pu}$ is hindered by the presence of even minute amounts of ${ }^{238} \mathrm{U}$ in the $\mathrm{Pu}$ fraction. For the determination of ${ }^{241} \mathrm{Pu}$ liquid scintillation counting could be a good choice. If the comprehensive characterization of the sample is necessary, the rational use of all methods might be called for.

Automatic flow-based sorbent extraction methods have been herein presented as potential substitutes of manual procedures that are tedious and labour-intensive. Notable advantages of these systems include the improved analysis time, the mechanization of sample processing, the minimal contact of the analyst with hazardous radionuclides and the drastic reduction in the consumption of sample and chemical reagents, hence resulting in less waste production, which is of particular importance nowadays due to the increasing costs in the disposal of chemical wastes. The application of FI/SI for automated radiochemical assays is however limited to a few laboratories, and traditional batchwise methods are still commonplace. This might be consequence of the downscaling of the column separation procedure, which might be inappropriate for concentration of large volumes of samples (often tens to hundreds of litres) for sensitive quantification of $\mathrm{Pu}$ at environmentally relevant levels. In other instances, the decontamination factors obtained on-line are not high enough for accurate analysis. The progressive degradation of the sorbent material with repetitive use and sample cross-contamination are other well-known limitations of FI/SI systems with permanent columns. However, this drawback can be elegantly overcome by exploitation of the 'bead injection' concept, where the sorptive surfaces are replaced automatically with fresh beads after each analytical run $[139,140]$. However, with the requirement of rapid assays of $\mathrm{Pu}$ for emergency purposes and the increased application of ICP-MS, the hyphenation of FI/SI column separation with ICP-MS is expected to be exploited in the near future as a routine technique for environmental monitoring. 


\section{Acknowledgements}

The authors are grateful to Sven P. Nielsen for his help and useful suggestions during the preparation of this article.

\section{References}

[1] D.M.Taylor, Appl. Radiat. Isot., 46 (1995) 1245-1252.

[2] V.P.Perelygin and Y.T.Chuburkov, Radiat. Meas., 28 (1997) 385-392.

[3] L.R.Morss, N.M.Edelstein, and J.Fuger, The Chemistry of the Actinide and Transactinide Elements, Springer, Dordrecht, 2006.

[4] B.F.Myasoedov and F.I.Pavlotskaya, Analyst, 114 (1989) 255-263.

[5] J.H.Hartley, J. Radiat. Res., 21 (1980) 83-104.

[6] M.S.Baxter, S.W.Fowler, and P.O.Povinec, Appl. Radiat. Isot., 11 (1995) 1213-1223.

[7] J.P.Garrec, T.Suzuki, Y.Mahara, D.C.Santry, S.Miyahara, M.Sugahara, J.Zheng, and A.Kudo, Appl. Radiat. Isot., 11 (1995) 1271-1278.

[8] Y.Mahara and A.Kudo, Appl. Radiat. Isot., 11 (1995) 1191-1201.

[9] A.Kudo, Y.Marhara, D.C.Santry, T.Suzuki, S.Miyahara, M.Sugahara, J.Zheng, and J.P.Garrec, Appl. Radiat. Isot., 11 (1995) 1089-1098.

[10] Z.Holgye and R.Filgas, J. Environ. Radioact., 22 (1995) 181-189.

[11] A.A.Cigna, L.C.Rossi, S.Sgorbini, and G.Zurlini, J. Environ. Radioact.,, 5 (1987) 71-81.

[12] E.P.Haroy, P.W.Krey, and H.L.Volchok, Nature, 241 (1973) 444-445.

[13] A.Aarkrog, J.Simmonds, P.Strand, C.Christensen, and B.Salbu, Radiological Assessment of Past Present and Potential Sources to Environmental Contamination in the Southern Urals and Strategies for Remedial Measures (SUCON). Risø-R-1243(EN), Risø National Laboratoy, (2000) 1-71.

[14] M.Baskaran, S.Asbill, J.Schwantes, P.Santschi, M.A.Champ, J.M.Brooks, D.Adkinson, and V.Makeyev, Mar. Pollut. Bull., 40 (2000) 830-838.

[15] M.Eriksson, On Weapons Plutonium in the Arctic Environment (Thuler, Greenland), Risø-R-1321(EN), Risø National Laboratory, (2002) 1-146. (PhD Thesis) 
[16] O.C.Lind, B.Salbu, K.Janssens, K.Proost, and H.Dahlgaard, J. Environ. Radioact., 81 (2005) 21-32.

[17] C.Duffa and P.Renaud, Sci. Total Environ., 348 (2005) 164-172.

[18] P.P.Povine, A.Aarkrog, K.O.Buesseler, R.Delfanti, K.Hirose, G.H.Hong, T.Ito, H.D.Livingston, H.Nies, V.E.Noshkin, S.Shima, and O.Togawa, J. Environ. Radioact., 81 (2005) 63-87.

[19] M.C.Jimenez-Ramos, R.Garcia-Tenorio, I.Vioque, G.Manjon, and M.Garcia-Leon, Environ. Pollut. 142 (2006) 487-492.

[20] O.C.Lind, B.Salbu, K.Janssens, K.Proost, M.Garcria-Leon, and R.Garcia-Tenorio, Sci. Total Environ., 376 (2008) 294-305.

[21] UNSCEAR, Source and Effect of Ionizing Radiation-UNSCEAR1993Report, (1993) 121.

[22] J.H.Harley, USAEC Report HASL-149, (1964) 139.

[23] UNSCEAR, Source and Effect of Ionizing Radiation-UNSCEAR2000Report Volume II:Effect, (2000) 519.

[24] J.Gray, S.R.Jones, and A.D.Smith, J. Radio. Prot., 15 (1995) 99.

[25] BNFL, Annual report on discharges and monitoring of the environment. BNFL(1995-2005), (2005).

[26] IRRIN, Inventoire des rejets radioactifis des installations nucleaires. Group Radioecologie Bord Contentin, 1 (1999).

[27] ATSDR, Toxicological Profile For Plutonium, Agency for Toxic Substances and Disease Registry, http://www. atsdr. cdc. gov/toxprofiles/tp143. html, (2007) 151-176.

[28] P.P.Povinec, A.Aarkrog, K.O.Buesseler, R.Delfanti, K.Hirose, G.H.Hong, T.Ito, H.D.Livingston, H.Nies, V.E.Noshkin, S.Shima, and O.Togawa, J. Environ. Radioac., 81 (2005) 63-87.

[29] E.Holm, Appl. Radiat. Isot., 46 (1995) 1225-1229.

[30] A.E.Eroglu, C.W.Mcleod, K.S.Keonard, and D.McCubbin, Spectrochim. Acta B, 53 (1998) 1221-1233.

[31] IAEA, Environmental Consequences of the Chernobyl Accident and their Remediation:Twenty Years of Experience, International Atomic Energy Agency, Radiological Assessment Report Series, STI/PUB/1239 (2006) 1-96.

[32] J.M.Cleveland, The Chemistry of Plutonium, American Nuclear Society, La Grange Park, IL 1979.

[33] J.Ruzicka and E.H.Hansen, Flow Injection Analysis, Wiley-Interscience, New York, 1988.

[34] M.Miro and W.Frenzel, Microchim. Acta, 148 (2004) 1-20.

[35] E.H.Hansen and M.Miro, TrAC-Trends Anal. Chem., 26 (2007) 18-26.

[36] M.Trojanowicz (Ed), Advances in Flow Analysis, Wiley-VCH Verlag, Weinheim, 2008. 
[37] S.D.Kolev and I.D.McKelvie, Flow Injection Analysis, In Comprehensive Analytical Chemistry, Elsevier, The Netherlands, 2008.

[38] A.Economou, TrAC-Trends Anal. Chem., 24 (2005) 416-425.

[39] C.F.Lenehan, N.W.Barnett, and S.W.Lewis, Analyst, 127 (2002) 997-1020.

[40] E.H.Hansen and J.H.Wang, Anal. Chim. Acta, 467 (2002) 3-12.

[41] M.Miro and E.H.Hansen, On-line Processing Methods in Flow Analysis, In: Advances in Flow Methods of Analysis, Wiley-VCH, Weinhem, (2008) 291-320.

[42] M.Miro and E.H.Hansen, TrAC-Trends Anal. Chem., 25 (2006) 267-281.

[43] M.Miro, E.H.Hansen, R.Chomchoei, and W.Frenzel, Trends. Anal. Chem., 24 (2005) 759-771.

[44] A.Anthemidis and M.Miro. Applied Spectr. Rev., 2009, in Press

[45] R.Jakopic, P.Tavcar, and L.Benedik, Appl. Radio. Isot., 65 (2007) 504-511.

[46] M.E.Ketterer, K.M.Hafer, and J.W.Mietelski, J. Radioanal. Nucl. Chem., 73 (2004) 183-201.

[47] S.F.Boulyga, D.Desideri, and M.A.Meli, Inter. J. Mass Spectrom., 226 (2003) 329-339.

[48] P.E.Warwick, I.W.Croudace, and J.S.Oh, Anal. Chem., 73 (2001) 3410-3416.

[49] M.P.R.Montero, A.M.Sanchez, M.T.C.Vazquez, and J.L.G.Murillo, Appl. Radiat. Isot., 53 (2000) $259-264$.

[50] L.Moreno, N.Vaida, P.R.Danesi, J.J.La Rosa, E.Zeiller, and M.Sinojmeri, J. Radioanal. Nucl. Chem., 226 (1997) 279-284.

[51] N.Momoshima, H.Kakiuchi, Y.Maeda, E.Hirai, and T.Ono, J. Radioanal. Nucl. Chem., 221 (1997) 213-217.

[52] S.Tonouchi, H.Habuki, K.Katoh, K.Yamazaki, and T.Hashimoto, J. Radioanal. Nucl. Chem., 252 (2002) $367-371$.

[53] S.H.Lee, J.J.La Rosa, J.Gastaud, and P.P.Povine, J. Radioanal. Nucl. Chem., 263 (2005) 419-425.

[54] Z.Varga, G.Suranyi, N.Vajda, and Z.Stefanka, Microchem. J., 85 (2007) 39-45.

[55] P.Tavcar, R.Jakopic, and L.Benedik, Acta. Chim. Slov., 52 (2005) 60-66.

[56] E.Hrnecek, P.Steier, and A.Wallner, Appl. Radiat. Isot., 63 (2005) 633-638.

[57] G.Kim, W.C.Burnett, and E.P.Horwitz, Anal. Chem., 72 (2000) 4882-4887.

[58] O.F.X.Donard, F.Bruneau, M.Moldovan, H.Garraud, V.N.Epov, and D.Boust, Anal. Chim. Acta, 587 (2007) 170179.

[59] S.Sturup, H.Dahlgaard, and S.C.Nielsen, J. Anal. At. Spectrom., 13 (1998) 1321-1326.

[60] S.M.Jerome, D.Smith, M.J.Woods, and S.A.Woods, Appl. Radiat. Isot., 46 (1995) 1145-1150.

[61] J.Mellado, M.Llaurado, and G.Rauret, Anal. Chim. Acta, 443 (2001) 81-90. 
[62] S.H.Lee, J.Gastaud, J.J.La Rosa, L.L.W.Kwong, P.P.Povinec, E.Wyse, L.K.Fifield, P.A.Hausladen, L.M.Di Tada, and G.M.Santos, J. Radioanal. Nucl. Chem., 248 (2001) 757-764.

[63] L.Perna, F.Bocci, L.A.de las Heras, J.De.Pablo, and M.Betti, J. Anal. At. Spectrom., 17 (2002) 1166-1171.

[64] J.B.Truscott, P.Jones, B.E.Fairman, E.Fairman, and E.H.Evans, J. Chromatogr. A, 928 (2001) 91-98.

[65] M.Toribio, J.F.Garcia, G.Rauret, R.Pilvio, and M.Bickel, Anal. Chim. Acta, 447 (2001) 179-189.

[66] I.Croudace, P.Warwick, R.Taylor, and S.Dee, Anal. Chim. Acta, 371 (1998) 217-225.

[67] M.Nunnemann, M.Erdmann, H.U.Hasse, G.Huber, J.V.Kratz, P.Kunz, A.Mansel, G.Passler, O.Stetzer,

N.Trautmann, and A.Waldek, J. Alloy. Comp., 271-273 (1998) 45-48.

[68] L.L.Smith, J.S.Crain, J.S.Yaeger, E.P.Howitz, H.Diamond, and R.Chiarizia, J. Radioanal. Nucl. Chem. Articles, 194 (1995) 151-156.

[69] L.L.W.Kwong, J.Gsatand, J.J.La Rosa, S.H.Lee, P.P.Povine, and E.Wyse, J. Radioanal. Nucl. Chem., 261 (2004) 283-289.

[70] M V.Zoriy, C.Pickhardt, P.Ostapczuk, R.Hille, and J.S.Becker, Inter. J. Mass Spectrom., 232 (2004) 217-224.

[71] Z.Varga, G.Suranyi, N.Vajda, and Z.Stefanka, J. Radioanal. Nucl. Chem., 274 (2007) 87-94.

[72] D.Schamloffel, P.Giusti, M.V.Zoriy, C.Pickhardt, J.Szpunar, R.Lobinski, and J.S.Becker, J. Anal. At. Spectrom., 20 (2005) 17-21.

[73] Q.J.Chen, A.Aarkrog, S.P.Nielsen, H.Dahlgaard, H.Nies, Y.X.Yu, and K.Mandrup, J. Radioanal. Nucl. Chem., 172 (1993) 281-288.

[74] K.Norisuye, K.Okamura, Y.Sohrin, H.Hasegawa, and T.Nakanish, J. Radioanal. Nucl. Chem., 267 (2006) 183-193.

[75] C.K.Kim, Y.Oura, Y.Takaku, H.Nitta, Y.Igarashi, and N.Ikeda, J. Radioanal. Nucl. Chem., 136 (1989) 353-362.

[76] H.Rameback and M.Skllberg, J. Radioanal. Nucl. Chem., 235 (1998) 229-233.

[77] H.Rameback and M.Skllberg, J. Radioanal. Nucl. Chem., 240 (1999) 661-663.

[78] M. Ayranov, U. Krahebuhl, H. Sahli, S. Rollin, M. Burger, Radiochim. Acta, 93 (2005) 249-257.

[79] E.L.Cooper, M.K.Haas, and J.F.Mattie, Appl. Radiat. Isot., 11 (1995) 1159-1173.

[80] E.P.Horwitz, R.Chiarizia, H.Diamond, and R.C.Gatrone, Solv. Extr. Ion Exch., 11 (1993) 943-966.

[81] Q.J.Chen, H.Dahlgaard, S.P.Nielsen, and A.Aarkrog, J. Radioanal. Nucl. Chem., 253 (2002) 451-458.

[82] X.L.Hou, S.Q.Zhang, J.X.Hu, X.F.Wei, and H.G.Zhao, Chinese Journal of Nuclear Science and Engineering, 15 (1995) 165-171. 
[83] E.P.Horwitz, M.L.Dietz, R.Chiarizia, H.Diamond, I. S.L.Maxwell, and M.R.Nelson, Anal. Chim. Acta, 310 (1995) 63-78.

[84] E.P.Horwitz, R.Chiarizia, M.L.Dietz, and H.Diamond, Anal. Chim. Acta, 281 (1993) 361-372.

[85] J.H.Kaye, R.S.Strebin, and R.Orr, J. Radioanal. Nucl. Chem., 194 (1995) 191-196.

[86] E.P.Horwitz, M.L.Dietz, R.Chiarizia, and H.Diamond, Anal. Chim. Acta, 266 (1992) 37.

[87] J.Jernstrom, J.Lehto, and M.Betti, J. Radioanal. Nucl. Chem., 274 (2007) 95-102.

[88] Y.Muramatsu, S.Uchida, K.Tagami, S.Yoshida, and T.Fujikawa, J. Anal. At. Spectrom., 14 (1999) 859-865.

[89] P.Lindahl, P.Roos, E.Holm, and H.Dahlgaard, J. Environ. Radioact., 82 (2005) 285-301.

[90] R.Pilvio and M.Bickel, J. Alloy. Comp., 271-273 (1998) 49-53.

[91] X.L.Hou. and P.Roos, Anal. Chim. Acta, 608 (2008) 105-139.

[92] S.K.Aggarwal, M.K.Saxena, and H.C.Jain, J. Radioanal. Nucl. Chem., 156 (1992) 111-118.

[93] L.L.W.Kwong, J.J.La Rosa, S.H.Lee, and P.P.Povinec, J. Radioanal. Nucl. Chem., 248 (2001) 751-755.

[94] J.Kuwabara and H.Noguchi, J. Radioanal. Nucl. Chem., 252 (2002) 273-276.

[95] L.K.Fifield, H.A.Synal, and M.Suter, Nucl. Instr. and Meth. B 223-224 (2004) 802-806.

[96] J.E.McAninch, T.F.Hamilton, T.A.Brown, T.A.Jokela, and J.P.Knezovich, Nucl. Instr. and Meth. B, 172 (2000) 711-716.

[97] Y.Igarashi, C.K.Kim, Y.Takaku, K.Shiraishi, M.Yamamoto, and N.Ikeda, Anal. Sci., 6 (1990) 157-164.

[98] C.S.Kim, C.K.Kim, P.Martin, and U.Sansone, J. Anal. At. Spectrom., 22 (2007) 827-841.

[99] M.Betti, L.A.de las Heras, and G.Tamborini, Appl. Spectros. Rev., 41 (2006) 491-514.

[100] K.Wendt and N.Trautmann, Inter. J. Mass Spectrom., 242 (2005) 161-168.

[101] D.Lariviere, V.F.Taylor, R.D.Evans, and R.J.Cornett, Spectrom. Acta B, 61 (2006) 877-904.

[102] F.V.Vanhaecke, M.Van Holderbeke, L.Moreno, and R.Dams, J. Anal. At. Spectrom., 11 (1996) 543-548.

[103] S.Augagneur, B.Medina, J.Szpunar, and R.Lobinski, J. Anal. At. Spectrom., 11 (1996) 713-721.

[104] S.H.Han, J.S.Lim, and A.Montaser, J. Anal. At. Spectrom., 9 (1994) 1357-1362.

[105] H.Liu and A.Montaser, Anal. Chem., 66 (1994) 3233-3242.

[106] J.W.Olesik, J.A.Kinzer, and B.Harkleroad, Anal. Chem., 66 (1994) 2022-2030.

[107] S.A.Pergantis, E.M.Heithmar, and T.A.Hinners, Anal. Chem., 67 (1995) 4530-4535.

[108] H.Liu, A.Montaser, S.P.Dolan, and R.S.Schwartz, J. Anal. At. Spectrom., 11 (1996) 307-300.

[109] H.Liu, R.H.Clifford, S.P.Dolan, and A.Montaser, Spectrochim. Acta B, 51 (1996) 27-40. 
[110] K.E.Lawrence, G.W.Rice, and V.A.Fassel, Anal. Chem., 56 (1984) 289-292.

[111] D.R.Wiederin, F.G.Smith, and R.S.Houk, Anal. Chem., 63 (1991) 219-225.

[112] S.C.Shum and R.S.Houk, Anal. Chem., 65 (1993) 2972-2976.

[113] L. Wang, S.W.May, R.F.Browner, and S.H.Pollock, J. Anal. At. Spectrom., 11 (1996) 1137-1146.

[114] K.L.Sutton, C.B.Hymer, and J.A.Caruso, J. Anal. At. Spectrom., 13 (1998) 885-891.

[115] J.S.Becker and H. J. Dietze, J. Anal. At. Spectrom., 14 (1999) 1493-1500.

[116] J.S.Becker and H. J. Dietze, Anal. Chem., 71 (1999) 3077-3084.

[117] J.A.Mclean, M.G.Minnich, L.A.Iacon, H.Liu, and A.Montaser, J. Anal. At. Spectrom., 13 (1998) 829-842.

[118] J.A.Mclean, H.Zhang, and A.Montaser, Anal. Chem., 70 (1998) 1012-1020.

[119] S.Boulyga, M.Tibi, and K.G.Heumann, Anal. Bioanal. Chem., 378 (2004) 342-347.

[120] L.K.Fifield, R.G.Cresswell, M.L.di Tada, T.R.Ophel, J.P.Day, A.P.Clacher, S.J.King, and N.D.Priest, Nucl. Instr. and Meth. B, 117 (1996) 295-303.

[121] D.W.Efurd, R.E.Steiner, F.R.Roensch, S.E.Glover, and J.A.Musgrave, J. Radioanal. Nucl. Chem., 263 (2005) 387-391.

[122] C.Gruning, G.Huber, P.Klopp, J.V.Kratz, P.Kunz, and G.Passler, Inter. J. Mass Spectrom., 235 (2004) 171-178.

[123] A.V.Muravitsky, V.F.Razbudey, V.V.Tokarevsky, and P.N.Voron, Appl. Radiat. Isot., 63 (2005) 487-492.

[124] J.B.Truscott, P.Jones, B.E.Fairman, and E.H.Evans, Anal. Chim. Acta, 433 (2001) 245-253.

[125] J.Ruzicka and E.H.Hansen, Anal. Chim. Acta, 78 (1975) 145-157.

[126] J.Ruzicka and G.D.Marshall, Anal. Chim. Acta, 237 (1990) 329-343.

[127] J.W.Grate and O.B.Egorov, Anal. Chem., 70 (1998) 779A-788A.

[128] O.Egorov, J.W.Grate, and J.Ruzicka, J. Radioanal. Nucl. Chem., 243 (1998) 231-235.

[129] Y. Fajardo, L. Ferrer, E. Gómez, F. Garcias, M. Casas, V. Cerdà, Anal. Chem., 80(2008) 195-202.

[130] J.W.Grate and O.B.Egorov, Anal. Chem., 70 (1998) 3920-3929.

[131] J.W.Grate, O.Egorov, and S.K.Fiskum, Analyst, 124 (1999) 1143-1150.

[132] O.B.Egorov, M.J.O'Hara, O.T.Farmer III, and J.W.Grate, Analyst, 126 (2001) 1594-1601.

[133] C.S.Kim, C.K.Kim, and K.J.Lee, J. Anal. At. Spectrom., 19 (2004) 743-750.

[134] V.N.Epov, R.D.Evans, J.Zheng, O.F.X.Donard, and M.Yamada, J. Anal. At. Spectrom., 22 (2007) 1131-1137.

[135] C.S.Kim, C.K.Kim, J.I.Lee, and K.J.Lee, J. Anal. At. Spectrom., 15 (2000) 247-255.

[136] C.S.Kim and C.K.Kim, Anal. Chem., 74 (2002) 3824-3832. 
[137] C.K.Kim, C.S.Kim, U.Sansone, and P.Martin, Appl. Radiat. Isot., 66 (2008) 223-230.

[138] V.N.Epov, K.Benkhedda, and R.D.Evans, J. Anal. At. Spectrom., 20 (2005) 990-992.

[139] E.Egorov, M.J.O'Hara, and J.W.Grate, Anal. Chem., 71 (1999) 345-352.

[140] M.Miro, S.Kradtap-Hartwell, J.Jakmunee, K.Grudpan, and H.H. E, TrAC-Trends Anal. Chem., 27 (2008) 749761.

Table 1. Nuclear Properties of Pu Isotopes [3]

Table 2. Sources of Pu in the environment (Bq)

Table 3. ${ }^{238} \mathrm{Pu}$ and ${ }^{239,240} \mathrm{Pu}$ concentrations in oceans and some specific locations after nuclear accidents

Table 4. Electrochemical potentials for redox couples related to plutonium ions in acidic, neutral, and alkaline aqueous solution versus the standard hydrogen electrode [3]

Table 5. Reagents for oxidation and reduction of plutonium ions [32]

Table 6. Formation of $\mathrm{Pu}$ complexes with $\mathrm{NO}_{3}{ }^{-}$and $\mathrm{Cl}^{-}[32]$

Table 7. Comparison of different techniques for detection of Pu isotopes

Table 8. Comparison of analytical procedures using different separation methods for determination of $\mathrm{Pu}$ in environmental samples

Table 9. Comparison of different analytical procedures for automatic determination of Pu exploiting flow-based approaches 
Table 1. Nuclear Properties of Pu Isotopes [3]

\begin{tabular}{|c|c|c|c|c|c|}
\hline & Half-life & $\begin{array}{c}\text { Specific activity } \\
\left(\mathrm{Bq} \mathrm{g}^{-1}\right)\end{array}$ & $\begin{array}{c}\text { Principal decay } \\
\text { mode }\end{array}$ & Decay energy $(\mathrm{MeV})$ & $\begin{array}{c}\text { Example of } \\
\text { production method }\end{array}$ \\
\hline \multirow[t]{2}{*}{${ }^{238} \mathrm{Pu}$} & $87.7 \mathrm{yr}$ & $6.338 \times 10^{11}$ & $\alpha$ & $\alpha 5.499(70.9 \%)$ & ${ }^{242} \mathrm{Cm}$ daughter \\
\hline & $4.77 \times 10^{10} \mathrm{yr}$ & $1.165 \times 10^{3}$ & SF $1.85 \times 10^{-7} \%$ & $5.456(29.0 \%)$ & ${ }^{238} \mathrm{~Np}$ daughter \\
\hline \multirow[t]{3}{*}{${ }^{239} \mathrm{Pu}$} & $2.411 \times 10^{4} \mathrm{yr}$ & $2.296 \times 10^{9}$ & $\alpha$ & $\alpha 5.157(70.77 \%)$ & ${ }^{239} \mathrm{~Np}$ daughter \\
\hline & $8.5 \times 10^{15} \mathrm{yr}$ & $6.512 \times 10^{-3}$ & SF $3.0 \times 10^{-10} \%$ & $5.144(17.11 \%)$ & \\
\hline & & & & $\begin{array}{c}5.106(11.94 \%) \\
\gamma 0.129\end{array}$ & \\
\hline \multirow[t]{2}{*}{${ }^{240} \mathrm{Pu}$} & $6.561 \times 10^{3} \mathrm{yr}$ & $8.401 \times 10^{9}$ & $\alpha$ & $\alpha 5.168(72.8 \%)$ & Multiple $\mathrm{n}$ capture \\
\hline & $1.15 \times 10^{11} \mathrm{yr}$ & $4.793 \times 10^{2}$ & SF $5.75 \times 10^{-6} \%$ & $5.124(27.1 \%)$ & \\
\hline${ }^{241} \mathrm{Pu}$ & $14.35 \mathrm{yr}$ & $3.825 \times 10^{12}$ & $\begin{array}{c}\beta^{-}>99.99 \% \\
\alpha 2.45 \times 10^{-3} \% \\
\text { SF } 2.4 \times 10^{-14} \%\end{array}$ & $\begin{array}{c}\alpha 4.896(83.2 \%) \\
4.853(12.2 \%) \\
\beta^{-} 0.021 \\
\gamma 0.149\end{array}$ & Multiple $\mathrm{n}$ capture \\
\hline${ }^{242} \mathrm{Pu}$ & $\begin{array}{l}3.75 \times 10^{5} \mathrm{yr} \\
6.77 \times 10^{10} \mathrm{yr}\end{array}$ & $\begin{array}{l}1.458 \times 10^{8} \\
8.075 \times 10^{2}\end{array}$ & $\begin{array}{c}\alpha \\
\text { SF } 5.54 \times 10^{-4} \%\end{array}$ & $\begin{array}{c}\alpha 4.902(76.49 \%) \\
4.856(23.48 \%)\end{array}$ & Multiple $n$ capture \\
\hline${ }^{244} \mathrm{Pu}$ & $\begin{array}{l}8.08 \times 10^{7} \mathrm{yr} \\
6.6 \times 10^{10} \mathrm{yr}\end{array}$ & $\begin{array}{l}6.710 \times 10^{5} \\
8.215 \times 10^{2}\end{array}$ & $\begin{array}{c}\alpha 99.88 \% \\
\text { SF } 0.1214 \%\end{array}$ & $\begin{array}{c}\alpha 4.589(81 \%) \\
4.546(19 \%)\end{array}$ & Multiple $\mathrm{n}$ capture \\
\hline
\end{tabular}

SF: Spontaneous fission. 
Table 2. Sources of $\mathrm{Pu}$ in the environment $(\mathrm{Bq})$

\begin{tabular}{|c|c|c|c|c|c|c|c|c|}
\hline \multicolumn{2}{|c|}{ Radionuclide } & ${ }^{238} \mathrm{Pu}$ & ${ }^{239} \mathrm{Pu}$ & ${ }^{240} \mathrm{Pu}$ & ${ }^{241} \mathrm{Pu}$ & ${ }^{242} \mathrm{Pu}$ & ${ }^{239+240} \mathrm{Pu}$ & Total \\
\hline \multicolumn{2}{|c|}{ Nuclear weapons testing $[4,21]$} & $3.3 \times 10^{14}$ & $6.5 \times 10^{15}$ & $4.4 \times 10^{15}$ & $1.4 \times 10^{17}$ & $1.6 \times 10^{13}$ & $12.6 \times 10^{15}$ & $1.7 \times 10^{17}$ \\
\hline \multicolumn{2}{|c|}{ Burn up of SNAP-9A satellite[22] } & $6.3 \times 10^{14}$ & - & - & - & - & - & $6.3 \times 10^{14}$ \\
\hline \multicolumn{2}{|c|}{ Aircraft accident in Palomares [5] } & - & - & - & - & - & $5.5 \times 10^{10}$ & $5.5 \times 10^{10}$ \\
\hline \multicolumn{2}{|c|}{$\begin{array}{l}\text { Aircraft accident in Thule, } \\
\text { Greenland, } 1968[15,16]\end{array}$} & - & - & - & - & - & $1 \times 10^{13}$ & $1 \times 10^{13}$ \\
\hline \multicolumn{2}{|c|}{ Nuclear power plant accident in } & $3.5 \times 10^{13}$ & $3 \times 10^{13}$ & $4.2 \times 10^{13}$ & $6 \times 10^{15}$ & $7.0 \times 10^{10}$ & $7.2 \times 10^{13}$ & $6 \times 10^{15}$ \\
\hline \multicolumn{2}{|c|}{$\begin{array}{l}\text { Reprocessing plant in Sellafield site } \\
{[24,25]}\end{array}$} & $1.2 \times 10^{14}$ & - & - & $2.2 \times 10^{16}$ & - & $6.1 \times 10^{14}$ & $2.2 \times 10^{16}$ \\
\hline \multicolumn{2}{|c|}{$\begin{array}{l}\text { Reprocessing plant in La Hague site } \\
\text { [26] }\end{array}$} & $2.7 \times 10^{12}$ & & & $1.2 \times 10^{14}$ & $1.7 \times 10^{9}$ & $3.4 \times 10^{12}$ & $1.4 \times 10^{14}$ \\
\hline \multirow{3}{*}{$\begin{array}{l}\text { Savannah } \\
\text { River Site, } \\
1954-1989 \\
{[27]}\end{array}$} & Release to air & - & - & - & - & - & - & $1.4 \times 10^{11}$ \\
\hline & Discharge to water & - & - & - & - & - & - & $2.3 \times 10^{10}$ \\
\hline & Discharge to soil & - & - & - & - & - & - & $2 \times 10^{11}$ \\
\hline
\end{tabular}


Table $3 .{ }^{238} \mathrm{Pu}$ and ${ }^{239+240} \mathrm{Pu}$ concentrations in oceans and given locations after nuclear accidents

\begin{tabular}{|c|c|c|c|}
\hline \multicolumn{2}{|c|}{ Area } & ${ }^{238} \mathrm{Pu}$ & ${ }^{239,240} \mathrm{Pu}$ \\
\hline \multicolumn{2}{|c|}{ Surface water of Pacific Ocean [28], $\mathrm{Bq} \mathrm{L}^{-1}$} & - & $(0.5-2.8) \times 10^{-6}$ \\
\hline \multicolumn{2}{|c|}{ Surface water of the Sea of Janpan [28], Bq L ${ }^{-1}$} & - & $(5.2 \pm 0.9) \times 10^{-6}$ \\
\hline \multicolumn{2}{|c|}{ Surface water of Indian Oceans [28], Bq L ${ }^{-1}$} & - & $(0.8-2.2) \times 10^{-6}$ \\
\hline \multicolumn{2}{|c|}{ Water in the Baltic Sea[29], $\mathrm{Bq} \mathrm{L}^{-1}$} & - & $(0.6-6) \times 10^{-6}$ \\
\hline \multicolumn{2}{|c|}{ Water in the Irish Sea [30], $\mathrm{Bq} \mathrm{L}^{-1}$} & - & $(1.0-3.8) \times 10^{-3}$ \\
\hline \multirow{5}{*}{$\begin{array}{l}\text { Lower Rhone } \\
\text { valley(Southern }\end{array}$} & Soil, Bq m${ }^{-2}$ & $1.4 \pm 0.1$ & $47.0 \pm 3.4$ \\
\hline & Fruit, Bq kg-1 & $1.5 \times 10^{-5}$ & $5 \times 10^{-4}$ \\
\hline & Leaf vegetables, $\mathrm{Bq} \mathrm{kg}^{-1}$ & $7 \times 10^{-5}$ & $2.3 \times 10^{-3}$ \\
\hline & Fruit vegetables, $\mathrm{Bq} \mathrm{kg}^{-1}$ & $1.8 \times 10^{-5}$ & $6 \times 10^{-4}$ \\
\hline & Grape (wine), $\mathrm{Bq} \mathrm{kg}^{-1}$ & $1.5 \times 10^{-5}$ & $5 \times 10^{-4}$ \\
\hline & Rice, $\mathrm{Bq} \mathrm{kg}^{-1}$ & $7 \times 10^{-6}$ & $1.7 \times 10^{-4}$ \\
\hline & Wheat, $\mathrm{Bq} \mathrm{kg}^{-1}$ & $4 \times 10^{-6}$ & $1.3 \times 10^{-4}$ \\
\hline & Forages, $\mathrm{Bq} \mathrm{kg}^{-1}$ & $3 \times 10^{-5}$ & $1.0 \times 10^{-3}$ \\
\hline \multirow{4}{*}{$\begin{array}{l}\text { Marine environment } \\
\text { at Thule, NW- } \\
\text { Greenland [19] }\end{array}$} & Seawater, $\mathrm{Bq} \mathrm{L}^{-1}$ & - & $(5-30) \times 10^{-6}$ \\
\hline & Seaweed, $\mathrm{Bq} \mathrm{kg}^{-1}$ & - & $0.15-1.14$ \\
\hline & Sediment in surface $0-3 \mathrm{~cm}$ layer, $\mathrm{Bq} \mathrm{kg}^{-1}$ & - & 0.12 \\
\hline & Surface soil-1966 [5], Bq m${ }^{-2}$ & - & $(1.2-120) \times 10^{4}$ \\
\hline \multirow{3}{*}{$\begin{array}{l}\text { Palomares accident, } \\
1966\end{array}$} & Surface soil-2001[19], Bq m${ }^{-2}$ & - & $8-57900$ \\
\hline & Air-1966 Mean [5], Bq m ${ }^{-3}$ & - & $(1.48-4.44) \times 10^{-5}$ \\
\hline & Air-1967 Mean [5], Bq m ${ }^{-3}$ & - & $(3.7-444) \times 10^{-6}$ \\
\hline \multirow{4}{*}{$\begin{array}{l}\text { Chernobyl accident } \\
{[31], 1986}\end{array}$} & 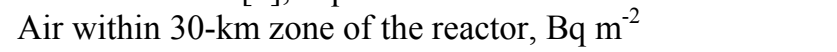 & - & $>4000$ \\
\hline & $\begin{array}{l}\text { Air in Gomel-Mogilev-Bryansk area ( } 200 \mathrm{~km} \text { north- } \\
\text { northeast of the reactor), } \mathrm{Bq} \mathrm{m}^{-2}\end{array}$ & - & $70-700$ \\
\hline & $\begin{array}{l}\text { Air in Kaluga-Tula-Orel area }(500 \mathrm{~km} \text { northeast of the } \\
\text { reactor), } \mathrm{Bq} \mathrm{m}^{-2}\end{array}$ & - & $70-300$ \\
\hline & Air in Korosten (115 km southwest of the reactor), $\mathrm{Bq} \mathrm{m}^{-2}$ & - & 60 \\
\hline
\end{tabular}


Table 4. Electrochemical potentials for redox couples related to plutonium ions in acidic, neutral, and alkaline aqueous solution versus the standard hydrogen electrode [3]

\begin{tabular}{cccc}
\hline Couple & Acidic & Neutral & Alkaline \\
\hline $\mathrm{Pu}(\mathrm{IV}) / \mathrm{Pu}(\mathrm{III})$ & +0.982 & -0.39 & -0.96 \\
$\mathrm{Pu}(\mathrm{V}) / \mathrm{Pu}(\mathrm{IV})$ & +1.170 & +0.70 & -0.67 \\
$\mathrm{Pu}(\mathrm{VI}) / \mathrm{Pu}(\mathrm{V})$ & +0.913 & +0.60 & +0.12 \\
$\mathrm{Pu}(\mathrm{VI}) / \mathrm{Pu}(\mathrm{IV})$ & +1.043 & +0.65 & +0.34 \\
$\mathrm{Pu}(\mathrm{V}) / \mathrm{Pu}(\mathrm{III})$ & - & +1.076 & - \\
$\mathrm{Pu}(\mathrm{VII}) / \mathrm{Pu}(\mathrm{VI})$ & - & - & +0.85 \\
$\mathrm{Pu}(\mathrm{V}) / \mathrm{Pu}(\mathrm{IV})$ & +1.17 & - & - \\
\hline
\end{tabular}


Table 5. Reagents for oxidation and reduction of plutonium [32]

\begin{tabular}{|c|c|c|c|c|}
\hline Reaction & Reagent & $\begin{array}{l}\text { Conditions } \\
\text { Solution }\end{array}$ & Temperature & Rate \\
\hline \multirow{2}{*}{$\begin{array}{l}\mathrm{Pu}(\mathrm{III}) \text { to } \\
\mathrm{Pu}(\mathrm{IV})\end{array}$} & $\mathrm{HNO}_{2}$ & Moderately concentrated acid & Room temp. & Rapid \\
\hline & $\begin{array}{l}\mathrm{H}_{2} \mathrm{O}_{2} \\
\mathrm{NO}_{3}^{-} \\
\mathrm{NaNO}_{2}\end{array}$ & $\begin{array}{c}\text { Various } \\
\text { Diluted acid } \\
0.5 \mathrm{~mol} \mathrm{~L}^{-1} \mathrm{HCl}\end{array}$ & $\begin{array}{l}\text { Room temp. } \\
\text { Room temp. } \\
\qquad 100^{\circ} \mathrm{C}\end{array}$ & $\begin{array}{l}\text { Depends on conditions } \\
\text { Extremely slow } \\
\mathrm{t}_{1 / 2}<1 \mathrm{~min}\end{array}$ \\
\hline \multirow[t]{2}{*}{$\begin{array}{c}\mathrm{Pu}(\mathrm{IV}) \text { to } \\
\mathrm{Pu}(\mathrm{III})\end{array}$} & Hydroquinone & Diluted $\mathrm{HNO}_{3}$ & Room temp. & Rapid \\
\hline & $\begin{array}{c}\text { Ascorbic acid } \\
\mathrm{NH}_{2} \mathrm{OH} \\
\mathrm{N}_{2} \mathrm{H}_{4} \\
\mathrm{I}^{-} \\
\mathrm{Fe}^{2+} \\
\mathrm{Ti}^{3+}\end{array}$ & $\begin{array}{c}\text { Moderately concentrated } \\
\mathrm{HNO}_{3}\left(4.75 \mathrm{~mol} \mathrm{~L}^{-1}\right) \\
0.25 \mathrm{~mol} \mathrm{~L}^{-1} \text { chloride salt } \\
0.25 \mathrm{~mol} \mathrm{~L}^{-1} \text { sulphate salt } \\
0.15 \mathrm{~mol} \mathrm{~L}^{-1} \mathrm{HI}, 0.4 \mathrm{M} \mathrm{HCl} \\
\text { Diluted acid } \\
\mathrm{HCl}\end{array}$ & $\begin{array}{l}\text { Room temp. } \\
\text { Room temp. } \\
\text { Room temp. } \\
\text { Room temp. } \\
\text { Room temp. } \\
\text { Room temp. }\end{array}$ & $\begin{array}{c}\text { Very rapid if } \mathrm{H}_{2} \mathrm{SO}_{4} \text { present, } \\
\text { otherwise reacts with } \mathrm{HNO}_{3} \\
\text { Completed in } 5 \mathrm{~min} \\
34 \% \text { completed in } 5 \mathrm{~min} \\
\text { Rapid } \\
\text { Rapid } \\
\text { Rapid }\end{array}$ \\
\hline \multirow[t]{2}{*}{$\begin{array}{l}\mathrm{Pu}(\mathrm{VI}) \text { to } \\
\mathrm{Pu}(\mathrm{IV})\end{array}$} & $\mathrm{Fe}^{2+}$ & $\mathrm{HCl}$ & Room temp. & Rapid \\
\hline & $\begin{array}{c}\mathrm{HNO}_{2} \\
\mathrm{HNO}_{2} \\
\mathrm{H}_{2} \mathrm{O}_{2} \\
\mathrm{Ti}^{3+} \\
\end{array}$ & $\begin{array}{c}0.55 \mathrm{~mol} \mathrm{~L}^{-1} \mathrm{HNO}_{3} \\
>15 \mathrm{~mol} \mathrm{~L}^{-1} \mathrm{HNO}_{3} \\
\text { Various } \\
\mathrm{HClO}_{4} \\
\end{array}$ & $\begin{array}{l}\text { Room temp. } \\
\quad 75^{\circ} \mathrm{C} \\
\text { Room temp. } \\
\text { Room temp. }\end{array}$ & $\begin{array}{c}\text { Very slow } \\
\text { Very rapid } \\
\text { Depends on conditions } \\
\text { Rapid } \\
\end{array}$ \\
\hline
\end{tabular}


Table 6. Formation of $\mathrm{Pu}$ ions complexes with $\mathrm{NO}_{3}{ }^{-}$and $\mathrm{Cl}^{-}$[32]

\begin{tabular}{|c|c|c|}
\hline Ion & $\mathrm{HNO}_{3}$ & $\mathrm{HCl}$ \\
\hline $\mathrm{Pu}^{3+}$ & $\begin{array}{l}\mathrm{Pu}^{3+}+\mathrm{NO}_{3}^{-} \leftrightarrow \mathrm{Pu}\left(\mathrm{NO}_{3}\right)^{2+}, \mathrm{K}_{1}=5.9 \pm 0.5^{\mathrm{a}} \\
\mathrm{Pu}\left(\mathrm{NO}_{3}\right)^{2+}+\mathrm{NO}_{3}^{-} \leftrightarrow \mathrm{Pu}\left(\mathrm{NO}_{3}\right)_{2}^{+}, \mathrm{K}_{2}=14.3 \pm 0.8^{\mathrm{a}} \\
\mathrm{Pu}\left(\mathrm{NO}_{3}\right)_{2}{ }^{+}+\mathrm{NO}_{3}^{-} \leftrightarrow \mathrm{Pu}\left(\mathrm{NO}_{3}\right)_{3}, \mathrm{~K}_{3}=14.4 \pm 0.8^{\mathrm{a}}\end{array}$ & $\begin{array}{l}\mathrm{Pu}^{3+}+\mathrm{Cl}^{-} \leftrightarrow \mathrm{PuCl}^{2+}, \mathrm{K}_{1}=4.9 \times 10^{-3} \mathrm{~b} \\
\mathrm{PuCl}^{2+}+\mathrm{Cl}^{-} \leftrightarrow \mathrm{PuCl}_{2}^{+}, \mathrm{K}_{2}=2.5 \times 10^{-3 \mathrm{c}}\end{array}$ \\
\hline \multirow[t]{2}{*}{$\mathrm{Pu}^{4+}$} & $\begin{array}{l}\mathrm{Pu}^{4+}+\mathrm{NO}_{3}^{-} \leftrightarrow \mathrm{Pu}\left(\mathrm{NO}_{3}\right)^{3+}, \mathrm{K}_{1}=5.5 \pm 0.2^{\mathrm{d}} \\
\mathrm{Pu}\left(\mathrm{NO}_{3}\right)^{3+}+\mathrm{NO}_{3}^{-} \leftrightarrow \mathrm{Pu}\left(\mathrm{NO}_{3}\right)_{2} 2^{2+}, \mathrm{K}_{2}=23.5 \pm 0.1^{\mathrm{d}} \\
\left.\mathrm{Pu}\left(\mathrm{NO}_{3}\right)_{2}\right)^{2+}+\mathrm{NO}_{3}{ }^{-} \leftrightarrow \mathrm{Pu}\left(\mathrm{NO}_{3}\right)_{3}{ }^{+}, \mathrm{K}_{3}=15 \pm 10^{\mathrm{d}}\end{array}$ & $\begin{array}{l}\mathrm{Pu}^{4+}+\mathrm{Cl}^{-} \leftrightarrow \mathrm{PuCl}^{3+}, \mathrm{K}_{1}=1.4 \pm 0.2^{\mathrm{d}} \\
\mathrm{PuCl}^{3+}+\mathrm{Cl}^{-} \leftrightarrow \mathrm{PuCl}_{2}^{2+}, \mathrm{K}_{2}=1.2 \pm 0.2^{\mathrm{d}} \\
\mathrm{PuCl}_{2}^{2}+\mathrm{Cl}^{-} \leftrightarrow \mathrm{PuCl}_{3}^{+}, \mathrm{K}_{3}=0.1 \pm 0.1^{\mathrm{d}}\end{array}$ \\
\hline & $\begin{array}{l}\mathrm{Pu}\left(\mathrm{NO}_{3}\right)_{3}{ }^{+}+\mathrm{NO}_{3}^{-} \leftrightarrow \mathrm{Pu}\left(\mathrm{NO}_{3}\right)_{4} \\
\mathrm{Pu}\left(\mathrm{NO}_{3}\right)_{4}+\mathrm{NO}_{3}^{-} \leftrightarrow \mathrm{Pu}\left(\mathrm{NO}_{3}\right)_{5}^{-} \\
\mathrm{Pu}\left(\mathrm{NO}_{3}\right)_{5}^{-}+\mathrm{NO}_{3}^{-} \leftrightarrow \mathrm{Pu}\left(\mathrm{NO}_{3}\right)_{6}{ }^{2-}\end{array}$ & \\
\hline $\mathrm{PuO}_{2}{ }^{2+}$ & $\begin{array}{l}\mathrm{PuO}_{2}{ }^{2+}+\mathrm{NO}_{3}^{-} \leftrightarrow \mathrm{PuO}_{2}\left(\mathrm{NO}_{3}\right)^{+} \\
\mathrm{PuO}_{2}\left(\mathrm{NO}_{3}\right)^{+}+\mathrm{NO}_{3}^{-} \leftrightarrow \mathrm{PuO}_{2}\left(\mathrm{NO}_{3}\right)_{2} \\
\mathrm{PuO}_{2}\left(\mathrm{NO}_{3}\right)_{2}+\mathrm{NO}_{3}^{-} \leftrightarrow \mathrm{PuO}_{2}\left(\mathrm{NO}_{3}\right)_{3}^{-}\end{array}$ & $\begin{array}{l}\mathrm{PuO}_{2}^{2+}+\mathrm{Cl}^{-} \leftrightarrow \mathrm{PuO}_{2} \mathrm{Cl}^{+}, \mathrm{K}_{1}=1.25^{\mathrm{f}} \\
\mathrm{PuO}_{2} \mathrm{Cl}^{+}+\mathrm{Cl}^{-} \leftrightarrow \mathrm{PuO}_{2} \mathrm{Cl}_{2}, \mathrm{~K}_{2}=0.35^{\mathrm{f}} \\
\mathrm{PuO}_{2} \mathrm{Cl}_{2}+\mathrm{Cl}^{-} \leftrightarrow \mathrm{PuO}_{2} \mathrm{Cl}_{3}^{-} \\
\mathrm{PuO}_{2} \mathrm{Cl}_{3}^{-}+\mathrm{Cl}^{-} \leftrightarrow \mathrm{PuO}_{2} \mathrm{Cl}_{4}^{2-}\end{array}$ \\
\hline
\end{tabular}

\footnotetext{
${ }^{a}$ Under the presence of hydrazine, at $20 \pm 1{ }^{\circ} \mathrm{C}$

${ }^{\mathrm{b}}$ Predominate in 2 8 $\mathrm{mol} \mathrm{L}^{-1} \mathrm{HCl}$ solution

${ }^{\mathrm{c}}$ Predominate in $>8 \mathrm{~mol} \mathrm{~L}^{-1} \mathrm{HCl}$ solution

${ }^{\mathrm{d}}$ In $4 \mathrm{~mol} \mathrm{~L}^{-1} \mathrm{HClO}_{4}$ solution, at $20^{\circ} \mathrm{C}$

${ }^{\mathrm{e}} \mathrm{In} 1 \mathrm{~mol} \mathrm{~L}^{-1} \mathrm{HCl}$ solution

${ }^{\mathrm{f}}$ Concentrations of $\mathrm{HCl}<1 \mathrm{~mol} \mathrm{~L}^{-1}$
} 
Table 7. Comparison of different techniques for detection of $\mathrm{Pu}$ isotopes

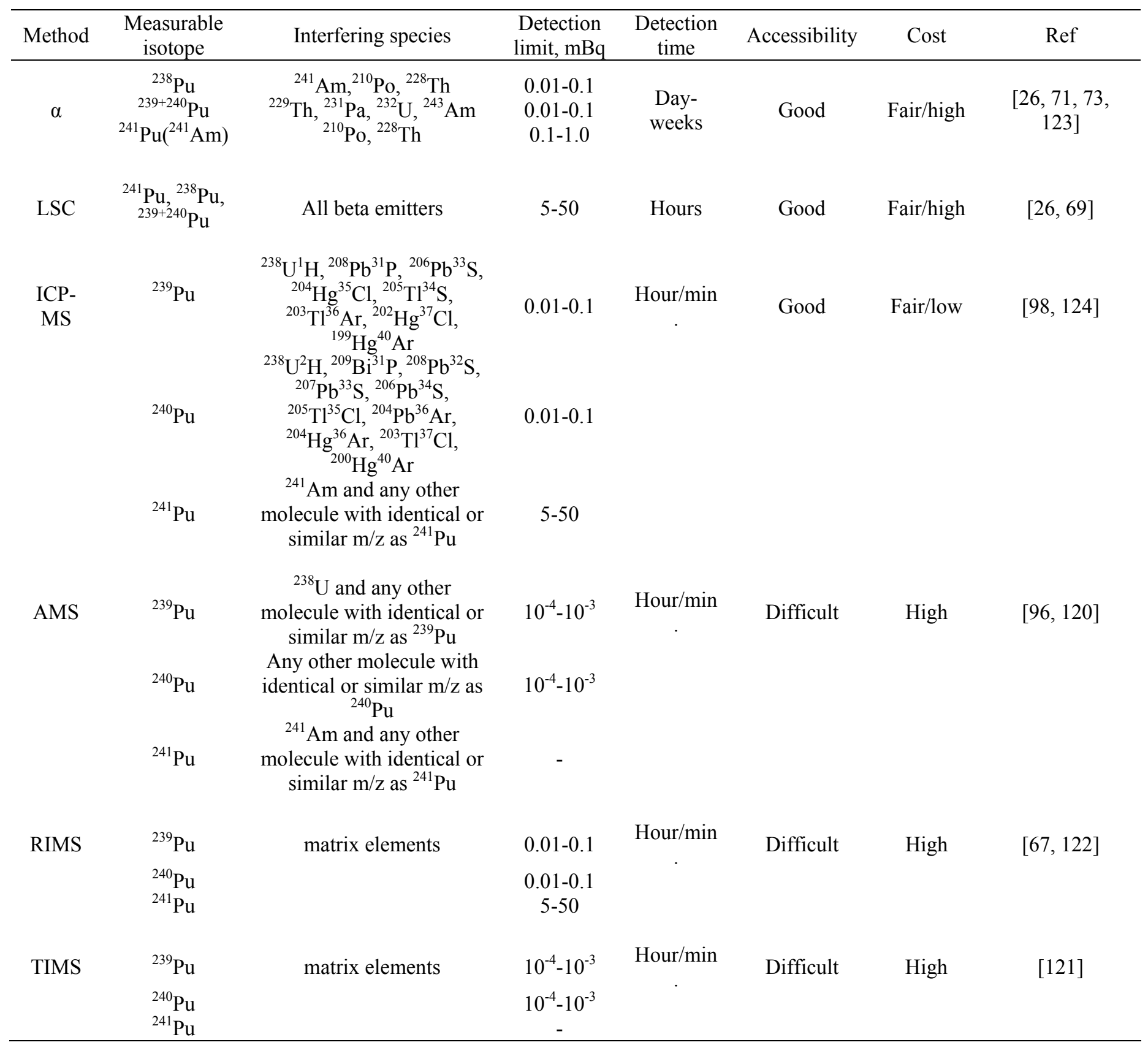


Table 8. Comparison of analytical procedures using different separation methods for determination of $\mathrm{Pu}$ in environmental samples

\begin{tabular}{|c|c|c|c|c|c|c|c|c|}
\hline Sample & $\begin{array}{c}\text { Separation } \\
\text { method }\end{array}$ & Valence adjustment & $\begin{array}{c}\text { Back } \\
\text { extraction/Eluent }\end{array}$ & $\begin{array}{c}\text { Chemical } \\
\text { yield }\end{array}$ & $\begin{array}{l}\text { Detection } \\
\text { method }\end{array}$ & Nuclide & $\begin{array}{l}\text { Detection } \\
\text { limit } \\
\end{array}$ & Ref \\
\hline Seawater & $\begin{array}{c}\text { Solvent } \\
\text { extraction } \\
\text { using TTA- } \\
\text { benzene }\end{array}$ & $6 \mathrm{~mol} \mathrm{~L}^{-1} \mathrm{NaNO}_{2}$ & $\begin{array}{c}10 \mathrm{~mol} \mathrm{~L}^{-1} \\
\mathrm{HNO}_{3}\end{array}$ & $96 \pm 2 \%$ & $\begin{array}{l}\alpha- \\
\text { spectrometry } \\
\text { ICP-MS }\end{array}$ & ${ }^{239} \mathrm{Pu},{ }^{230} \mathrm{Pu}$ & - & [74] \\
\hline $\begin{array}{l}\text { Plant and } \\
\text { sediment }\end{array}$ & $\begin{array}{l}\text { Solvent } \\
\text { extraction } \\
\text { using TOA- } \\
\text { xylene }\end{array}$ & - & $\begin{array}{c}0.1 \mathrm{~mol} \mathrm{~L}^{-1} \\
\mathrm{NH}_{4} \mathrm{I}-8.5 \mathrm{~mol} \\
\mathrm{~L}^{-1} \mathrm{HCl}\end{array}$ & $56-73 \%$ & $\begin{array}{c}\alpha- \\
\text { spectrometry } \\
\text { ICP-MS }\end{array}$ & ${ }^{239} \mathrm{Pu},{ }^{240} \mathrm{Pu}$ & - & {$[51]$} \\
\hline Seawater & AG $1 \times 4$ & $\mathrm{Na}_{2} \mathrm{SO}_{3}-\mathrm{NaNO}_{2}(\mathrm{~s})$ & $\begin{array}{c}\mathrm{HNO}_{3}, \mathrm{NaNO}_{3}- \\
\mathrm{HNO}_{3}\end{array}$ & $60-80 \%$ & $\begin{array}{c}\alpha- \\
\text { spectrometry }\end{array}$ & ${ }^{239+240} \mathrm{Pu}$ & - & [73] \\
\hline Sediment & Dowex $1 \times 4$ & 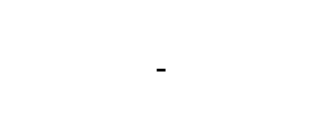 & $\begin{array}{c}1.2 \mathrm{~mol} \mathrm{~L}^{-1} \\
\mathrm{HCl}-0.6 \% \mathrm{H}_{2} \mathrm{O}_{2}\end{array}$ & - & SF-ICP-MS & $\begin{array}{l}{ }^{239} \mathrm{Pu} \\
{ }^{240} \mathrm{Pu} \\
{ }^{242} \mathrm{Pu}\end{array}$ & $\begin{array}{c}0.1 \mathrm{mBq} \\
0.08 \mathrm{mBq} \\
2 \mu \mathrm{Bq}\end{array}$ & [59] \\
\hline Soil & AG $1 \times 8$ & $\begin{array}{c}\mathrm{Fe}\left(\mathrm{NH}_{2} \mathrm{SO}_{3}\right)_{2} \cdot 6 \mathrm{H}_{2} \mathrm{O}- \\
\mathrm{NaNO}_{2}(\mathrm{~s})-\mathrm{HNO}_{3}\end{array}$ & $\begin{array}{c}0.1 \mathrm{~mol} \mathrm{~L}^{-1} \\
\mathrm{NH}_{4} \mathrm{I}-9 \mathrm{~mol} \\
\mathrm{~L}^{-1} \mathrm{HCl}\end{array}$ & - & $\begin{array}{c}\alpha- \\
\text { spectrometry } \\
\text { AMS }\end{array}$ & $\begin{array}{l}{ }^{238} \mathrm{Pu} \\
{ }^{239} \mathrm{Pu} \\
{ }^{240} \mathrm{Pu}\end{array}$ & $2 \mu \mathrm{q}$ & {$[56]$} \\
\hline Soil & $\begin{array}{l}\text { Bio Rad AG - } \\
\qquad 1 \times 8\end{array}$ & $\begin{array}{l}\mathrm{N}_{2} \mathrm{H}_{4} \cdot \mathrm{H}_{2} \mathrm{O}- \\
\mathrm{NaNO}_{2}(\mathrm{~s})\end{array}$ & $\begin{array}{c}0.1 \mathrm{~mol} \mathrm{~L}^{-1} \\
\mathrm{NH}_{4} \mathrm{I}^{-} \quad 9 \mathrm{~mol} \\
\mathrm{~L}^{-1} \mathrm{HCl}\end{array}$ & $>80 \%$ & $\begin{array}{c}\alpha- \\
\text { spectrometry }\end{array}$ & ${ }^{239+240} \mathrm{Pu}$ & - & {$[50]$} \\
\hline Soil & Dowex $1 \times 8$ & $\begin{array}{c}\mathrm{NH}_{2} \mathrm{OH} \cdot \mathrm{HCl}-1 \mathrm{~mol} \\
\mathrm{~L}^{-1} \mathrm{HCl}-\mathrm{NaNO}_{2}(\mathrm{~s})-8 \\
\mathrm{~mol} \mathrm{~L}^{-1} \mathrm{HNO}_{3}\end{array}$ & $\begin{array}{l}0.1 \mathrm{~mol} \mathrm{~L}^{-1} \mathrm{HI}-9 \\
\mathrm{~mol} \mathrm{~L}^{-1} \mathrm{HCl}\end{array}$ & $\sim 60 \%$ & $\begin{array}{c}\alpha- \\
\text { spectrometry }\end{array}$ & ${ }^{239+240} \mathrm{Pu}$ & - & [49] \\
\hline Soil & Dowex $1 \times 8$ & $\begin{array}{c}\mathrm{NaNO}_{2}(\mathrm{~s})-1 \mathrm{~mol} \mathrm{~L}^{-1} \\
\mathrm{HNO}_{3}\end{array}$ & $\begin{array}{c}9 \mathrm{~mol} \mathrm{~L}^{-1} \mathrm{HCl}- \\
\mathrm{H}_{2} \mathrm{O}_{2}\end{array}$ & $\sim 40 \%$ & $\begin{array}{c}\alpha- \\
\text { spectrometry }\end{array}$ & ${ }^{239+240} \mathrm{Pu}$ & - & [49] \\
\hline $\begin{array}{l}\text { Seaweed } \\
\quad \text { and } \\
\text { sediment }\end{array}$ & TEVA & $25 \%(w / w) \mathrm{NaNO}_{2}$ & $\begin{array}{c}0.1 \mathrm{~mol} \mathrm{~L}^{-1} \\
\mathrm{HNO}_{3}-0.1 \mathrm{~mol} \\
\mathrm{~L}^{-1} \mathrm{HF}\end{array}$ & $72-92 \%$ & $\begin{array}{c}\alpha- \\
\text { spectrometry } \\
\text { SF-ICP-MS } \\
\text { SF-ICP-MS } \\
\text { SF-ICP-MS }\end{array}$ & $\begin{array}{c}{ }^{238} \mathrm{Pu},{ }^{239} \mathrm{Pu} \\
{ }^{240} \mathrm{Pu} \\
{ }^{241} \mathrm{Pu} \\
{ }^{241} \mathrm{Pu}\end{array}$ & $\begin{array}{c}0.02 \mathrm{mBq} \\
0.021 \mathrm{mBq} \\
0.014 \mathrm{mBq} \\
11.9 \mathrm{mBq}\end{array}$ & {$[71]$} \\
\hline $\begin{array}{l}\text { Soil and } \\
\text { sediment }\end{array}$ & TEVA & - & $0.5 \mathrm{~mol} \mathrm{~L}^{-1} \mathrm{HCl}$ & $56-73 \%$ & $\begin{array}{c}\alpha- \\
\text { spectrometry } \\
\text { ICP-MS }\end{array}$ & ${ }^{239+240} \mathrm{Pu}$ & - & {$[51]$} \\
\hline $\begin{array}{l}\text { soil, tank } \\
\text { sludge } \\
\text { and } \\
\text { waste }\end{array}$ & TRU & $\begin{array}{c}\mathrm{NaNO}_{2}(\mathrm{~s})-2 \mathrm{~mol} \mathrm{~L}^{-1} \\
\mathrm{HNO}_{3}\end{array}$ & $\begin{array}{c}0.1 \mathrm{M} \\
\text { hydroquinone- } \\
4 \mathrm{~mol} \mathrm{~L}^{-1} \mathrm{HCl}\end{array}$ & - & $\begin{array}{c}\alpha- \\
\text { spectrometry }\end{array}$ & ${ }^{239+240} \mathrm{Pu}$ & - & {$[25]$} \\
\hline $\begin{array}{l}\text { soil and } \\
\text { sediment }\end{array}$ & UTEVA+TRU & $\begin{array}{c}\text { UTEVA: } \\
\mathrm{Fe}\left(\mathrm{NH}_{2} \mathrm{SO}_{3}\right)_{2} \cdot 6 \mathrm{H}_{2} \mathrm{O} \\
\text { - ascorbic acid } \\
\text { TRU: } 0.1 \mathrm{~mol} \mathrm{~L}^{-1} \\
\mathrm{NaNO}_{2}-2 \mathrm{~mol} \mathrm{~L}^{-1} \\
\mathrm{HNO}_{3}\end{array}$ & $\begin{array}{l}0.1 \mathrm{~mol} \mathrm{~L}^{-1} \\
\left(\mathrm{HN}_{4}\right)_{2} \mathrm{C}_{2} \mathrm{O}_{4}\end{array}$ & $\sim 80 \%$ & $\begin{array}{c}\alpha- \\
\text { spectrometry }\end{array}$ & ${ }^{239+240} \mathrm{Pu}$ & $\begin{array}{c}0.22 \sim 1.75 \\
\mathrm{mBq}\end{array}$ & {$[65]$} \\
\hline $\begin{array}{l}\text { Soil and } \\
\text { sediment }\end{array}$ & UTEVA+TRU & $\begin{array}{c}\text { UTEVA: } \\
\mathrm{Fe}\left(\mathrm{NH}_{2} \mathrm{SO}_{3}\right)_{2} \cdot 6 \mathrm{H}_{2} \mathrm{O} \\
\text {-ascorbic acid } \\
\text { TRU: } 0.1 \mathrm{~mol} \mathrm{~L}^{-1} \\
\mathrm{NaNO}_{2}-4 \mathrm{~mol} \mathrm{~L}^{-1} \\
\mathrm{HNO}_{3} \\
\end{array}$ & $\begin{array}{l}0.1 \mathrm{~mol} \mathrm{~L}^{-1} \\
\left(\mathrm{HN}_{4}\right)_{2} \mathrm{C}_{2} \mathrm{O}_{4}\end{array}$ & $\sim 80 \%$ & $\begin{array}{c}\alpha- \\
\text { spectrometry } \\
\text { SF-ICP-MS } \\
\text { SF-ICP-MS } \\
\text { SF-ICP-MS }\end{array}$ & $\begin{array}{l}{ }^{238} \mathrm{Pu} \\
{ }^{239} \mathrm{Pu} \\
{ }^{240} \mathrm{Pu} \\
{ }^{241} \mathrm{Pu}\end{array}$ & $\begin{array}{c}- \\
23 \sim 58 \mu \mathrm{Bq} \\
84 \sim 210 \mu \mathrm{Bq} \\
38 \sim 36 \mathrm{mBq}\end{array}$ & {$[54]$} \\
\hline
\end{tabular}


Table 8. Comparison of analytical procedures using different separation methods for determination of Pu in environmental samples (continue)

\begin{tabular}{|c|c|c|c|c|c|c|c|c|}
\hline Sample & Separation method & $\begin{array}{c}\text { Valence } \\
\text { adjustment }\end{array}$ & $\begin{array}{c}\text { Back } \\
\text { extraction/Eluent }\end{array}$ & $\begin{array}{c}\text { Chemical } \\
\text { yield }\end{array}$ & $\begin{array}{l}\text { Detection } \\
\text { method }\end{array}$ & Nuclide & $\begin{array}{l}\text { Detection } \\
\text { limit }\end{array}$ & Ref \\
\hline Sediment & TRU+UTEVA+TRU+Sr & $\begin{array}{c}1^{\text {st }} \text { TRU:NaNO } \mathrm{Na}_{2}(\mathrm{~s})- \\
\text { ascorbic acid } \\
\text { UTEVA: } \\
\mathrm{Fe}\left(\mathrm{NH}_{2} \mathrm{SO}_{3}\right)_{2} \cdot 6 \mathrm{H}_{2} \mathrm{O} \\
\text {-ascorbic acid } \\
2^{\text {nd }} \mathrm{TRU} 0.1 \mathrm{~mol} \\
\mathrm{~L}^{-1} \mathrm{NaNO}_{2}-2 \mathrm{~mol} \\
\mathrm{~L}^{-1} \mathrm{HNO}_{3}\end{array}$ & $\begin{array}{l}0.1 \mathrm{~mol} \mathrm{~L}^{-1} \\
\left(\mathrm{HN}_{4}\right)_{2} \mathrm{C}_{2} \mathrm{O}_{4}\end{array}$ & $84 \pm 6 \%$ & $\begin{array}{c}\alpha- \\
\text { spectrometry }\end{array}$ & ${ }^{239+240} \mathrm{Pu}$ & - & [61] \\
\hline $\begin{array}{l}\text { Sediment } \\
\text { and } \\
\text { spent } \\
\text { nuclear } \\
\text { fuel } \\
\text { samples }\end{array}$ & CS5A & $0.2 \mathrm{~mol} \mathrm{~L}^{-1} \mathrm{NaNO}_{2}$ & $2 \mathrm{~mol} \mathrm{~L}^{-1} \mathrm{HCl}$ & - & ICP-MS & $\begin{array}{l}{ }^{242} \mathrm{Pu} \\
{ }^{244} \mathrm{Pu}\end{array}$ & $\begin{array}{l}0.07 \mathrm{~Bq} \cdot \mathrm{ml}^{-1} \\
0.3 \mathrm{mBq} \cdot \mathrm{ml}^{-1}\end{array}$ & [63] \\
\hline Soil & PD-DVB & - & $\begin{array}{l}0.1 \mathrm{mmol} \mathrm{L}^{-1} \\
\text { dipicolinic acid- } \\
1.75 \mathrm{~mol} \mathrm{~L}^{-1} \\
\mathrm{HNO}_{3}\end{array}$ & - & SF-ICP-MS & ${ }^{239} \mathrm{Pu}$ & $18.4 \mu \mathrm{Bq}$ & [49] \\
\hline Sediment & $\begin{array}{c}\text { Bio Rad AG } 1 \times 8+ \\
\text { solvent extraction using } \\
\text { HTTA- xylene + Dowex } \\
\qquad 1 \times 8\end{array}$ & $\begin{array}{c}\text { BioAG 1X8: } \\
\mathrm{NaNO}_{2}-8 \mathrm{~mol} \mathrm{~L}^{-1} \\
\mathrm{HNO}_{3} \\
\text { Solvent extraction: } \\
\mathrm{Na}_{2} \mathrm{SO}_{3}\end{array}$ & $\begin{array}{c}\text { Bio AG 1X8: } \\
\mathrm{Na}_{2} \mathrm{SO}_{3}-0.8 \\
\mathrm{~mol} \mathrm{~L}^{-1} \mathrm{HNO}_{3} \\
\text { Solvent } \\
\text { extraction: } 8 \mathrm{~mol} \\
\mathrm{~L}^{-1} \mathrm{HNO} \\
\text { Dowex } 1 \mathrm{X} 8 \text { : } \\
\mathrm{NH}_{2} \mathrm{OH} \cdot \mathrm{HCl}-1 \\
\mathrm{~mol} \mathrm{~L}^{-1} \mathrm{HCl}\end{array}$ & $42 \%$ & SF-ICP-MS & $\begin{array}{l}{ }^{239} \mathrm{Pu} \\
{ }^{240} \mathrm{Pu} \\
{ }^{241} \mathrm{Pu} \\
{ }^{242} \mathrm{Pu} \\
{ }^{244} \mathrm{Pu}\end{array}$ & $\begin{array}{c}460 \sim 518 \mu \mathrm{Bq} \\
630 \sim 840 \mu \mathrm{Bq} \\
287 \sim 382 \mathrm{mBq} \\
11 \sim 15 \mu \mathrm{Bq} \\
0.13 \sim 0.15 \mu \mathrm{Bq}\end{array}$ & {$[58]$} \\
\hline $\begin{array}{l}\text { Soil and } \\
\text { sediment }\end{array}$ & TRU+ anion exchange & 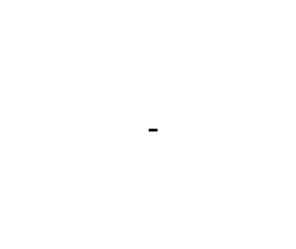 & $\begin{array}{c}\text { TRU: } 1 \mathrm{~mol} \mathrm{~L}^{-1} \\
\mathrm{HCl}-0.02 \mathrm{~mol} \mathrm{~L}^{-} \\
{ }^{1} \mathrm{HF} \\
\text { Anion exchange: } \\
\mathrm{NH}_{4} \mathrm{I}-9 \mathrm{~mol} \mathrm{~L}{ }^{-1} \\
\mathrm{HCl}\end{array}$ & $40 \sim 60 \%$ & $\begin{array}{c}\alpha- \\
\text { spectrometry }\end{array}$ & ${ }^{239+240} \mathrm{Pu}$ & - & [48] \\
\hline Soil & Chelating resin + TRU & $\begin{array}{c}\text { TRU: } 35 \% \\
\mathrm{Fe}\left(\mathrm{NH}_{2} \mathrm{SO}_{3}\right)_{2} \cdot 6 \mathrm{H}_{2} \mathrm{O} \\
-0.1 \mathrm{~mol} \mathrm{~L}^{-1} \\
\mathrm{NaNO}_{2}(\mathrm{~s})-2.5 \mathrm{~mol} \\
\mathrm{~L}^{-1} \mathrm{HNO}_{3}\end{array}$ & $\begin{array}{c}\text { Chelating resin: } \\
0.1 \mathrm{~mol} \mathrm{~L}^{-1} \\
\text { HDEHP } \\
\text { TRU: } 0.05 \mathrm{~mol} \\
\mathrm{~L}^{-1} \mathrm{TiCl}_{3}-4 \mathrm{~mol} \\
\mathrm{~L}^{-1} \mathrm{HCl}\end{array}$ & $85 \pm 5 \%$ & $\begin{array}{c}\alpha- \\
\text { spectrometry }\end{array}$ & ${ }^{239+240} \mathrm{Pu}$ & - & {$[57]$} \\
\hline $\begin{array}{l}\text { Soil and } \\
\text { sediment }\end{array}$ & $\begin{array}{c}\text { Dowex } 1 \mathrm{X} 8+\mathrm{TRU}+\mathrm{Sr}- \\
\text { Spec }\end{array}$ & $\begin{array}{l}\text { Dowex 1X8: } \\
\mathrm{NH}_{2} \mathrm{OH} \cdot \mathrm{HCl}- \\
\mathrm{NaNO}_{2}\end{array}$ & $\begin{array}{l}\text { Dowex 1X8: } \\
0.1 \mathrm{~mol} \mathrm{~L}^{-1} \mathrm{I}^{-}-9 \\
\mathrm{~mol} \mathrm{~L}^{-1} \mathrm{HCl}\end{array}$ & $61 \%$ & $\begin{array}{c}\alpha- \\
\text { spectrometry }\end{array}$ & ${ }^{239+240} \mathrm{Pu}$ & - & {$[55]$} \\
\hline $\begin{array}{l}\text { Artificial } \\
\text { solution }\end{array}$ & TEVA+ TCC-II + CS5A & $\begin{array}{l}\text { TEVA: ascorbic } \\
\text { acid- } \mathrm{NH}_{2} \mathrm{OH} \cdot \mathrm{HCl}\end{array}$ & $\begin{array}{c}\text { TEVA: } 0.5 \mathrm{~mol} \\
\mathrm{~L}^{-1} \mathrm{HCl} \\
\text { TCC-II: } 0.05 \\
\text { mol L }{ }^{-1} \mathrm{HCl} \\
\text { CS5A: } 0.018 \\
\text { mol L } \\
\text { dipicolinic acid- } \\
\text { 0.12 mol L } \\
\mathrm{NaOH}^{-1} 0.27 \mathrm{~mol} \\
\mathrm{~L}^{-1} \mathrm{CH}_{3} \mathrm{COOH} \\
\end{array}$ & - & $\begin{array}{c}\alpha- \\
\text { spectrometry }\end{array}$ & ${ }^{239} \mathrm{Pu}$ & - & [87] \\
\hline
\end{tabular}


Table 9. Comparison of different analytical procedures for automatic determination of Pu exploiting flow-based approaches

\begin{tabular}{|c|c|c|c|c|c|c|c|}
\hline $\begin{array}{l}\text { Separation } \\
\text { method }\end{array}$ & $\begin{array}{l}\text { Decontamination } \\
\text { factor of }{ }^{238} \mathrm{U}\end{array}$ & $\begin{array}{c}\text { Recovery } \\
\text { of } \mathrm{Pu}\end{array}$ & $\begin{array}{l}\text { Detection } \\
\text { technique }\end{array}$ & Nuclide & $\begin{array}{l}\text { Detection } \\
\text { limit }\end{array}$ & $\begin{array}{c}\text { Operation } \\
\text { time }\end{array}$ & Ref. \\
\hline FI-TRU & - & - & LSC & ${ }^{239} \mathrm{Pu}$ & - & - & [128] \\
\hline FI-TRU & - & $98-100 \%$ & LSC & ${ }^{239} \mathrm{Pu}$ & - & $10 \mathrm{~min}$ & [130] \\
\hline SI-TRU & - & $85 \%$ & $\begin{array}{l}\text { LSC \& } \alpha- \\
\text { spectrometry }\end{array}$ & $\begin{array}{l}{ }^{238} \mathrm{Pu} \\
{ }^{239+240} \mathrm{Pu} \\
{ }^{239} \mathrm{Pu}\end{array}$ & - & - & [131] \\
\hline SI-TRU & $3.0 \times 10^{5}$ & - & ICP-MS & $\begin{array}{l}{ }^{240} \mathrm{Pu} \\
{ }^{241} \mathrm{Pu} \\
{ }^{242} \mathrm{Pu}\end{array}$ & - & - & [132] \\
\hline SI-TRU & - & - & SF-ICP-MS & ${ }^{239} \mathrm{Pu}$ & $1.9 \mu \mathrm{Bq}$ & - & [124] \\
\hline $\begin{array}{l}\text { SI-Sr and } \\
\text { TEVA }\end{array}$ & $10^{4}-10^{5}$ & $>70 \%$ & SF-ICP-MS & $\begin{array}{l}{ }^{240} \mathrm{Pu} \\
{ }^{242} \mathrm{Pu}\end{array}$ & $\begin{array}{c}25 \mu \mathrm{Bq} \\
0.87 \mu \mathrm{Bq}\end{array}$ & $5 h^{*}$ & [135] \\
\hline $\begin{array}{l}\text { SI-Sr and } \\
\text { TEVA }\end{array}$ & $(1.6-3.8) \times 10^{4}$ & $>58 \%$ & SF-ICP-MS & $\begin{array}{l}{ }^{239} \mathrm{Pu} \\
{ }^{440} \mathrm{Pu}\end{array}$ & $\begin{array}{l}0.98 \mu \mathrm{Bq} \\
1.04 \mu \mathrm{Bq}\end{array}$ & $4 \mathrm{~h}$ & [136] \\
\hline SI-TEVA & $8.8 \times 10^{5}$ & $87-95 \%$ & SF-ICP-MS & $\begin{array}{l}{ }^{239} \mathrm{Pu} \\
{ }^{240} \mathrm{Pu}\end{array}$ & $\begin{array}{l}- \\
-\end{array}$ & $1 \mathrm{~h}$ & [133] \\
\hline $\begin{array}{c}\text { SI-Dowex 1- } \\
\text { X8 }\end{array}$ & - & $85-96 \%$ & $\alpha$-spectrometry & ${ }^{239+240} \mathrm{Pu}$ & - & $5.23 \mathrm{~h}$ & [137] \\
\hline $\begin{array}{c}\text { FI-AG MP- } \\
1 \mathrm{M}\end{array}$ & - & $>85 \%$ & ICP-DRC-MS & $\begin{array}{l}{ }^{239} \mathrm{Pu} \\
{ }^{240} \mathrm{Pu} \\
{ }^{241} \mathrm{Pu} \\
{ }^{244} \mathrm{Pu}\end{array}$ & $\begin{array}{l}0.07 \mu \mathrm{Bq} \\
0.04 \mu \mathrm{Bq} \\
0.72 \mathrm{mBq} \\
0.31 \mathrm{pBq}\end{array}$ & $30 \mathrm{~min}$ & [138] \\
\hline
\end{tabular}

*Total analysis time 


\section{Figure legends}

Fig. 1 Flow chart of the analytical procedure for the determination of $\mathrm{Pu}$ in environmental samples

Fig. 2. General flow sheet for separation of Pu using anion exchange extraction

Fig. 3. Diagram of a three-line FI system (a) and an SI set-up furnished with a syringe pump (b) $P P$ - peristaltic pump; $R 1$ - reaction coil $1 ; R 2$ - reaction coil $2 ; D$ - detector

Fig 4. An SI manifold equipped with an extraction chromatographic column hyphenated to the analytical detection system via an ancillary FI manifold. SP - syringe pump; HC - holding coil 1; S - sample ; $\mathrm{E}_{1}, \mathrm{E}_{2}$ - eluent 1, eluent 2 ; W1,W2 -washing solution1, washing solution 2; WS waste; MPV - multiport valve ; PP - peristaltic pump; C - carrier; V - valve. 


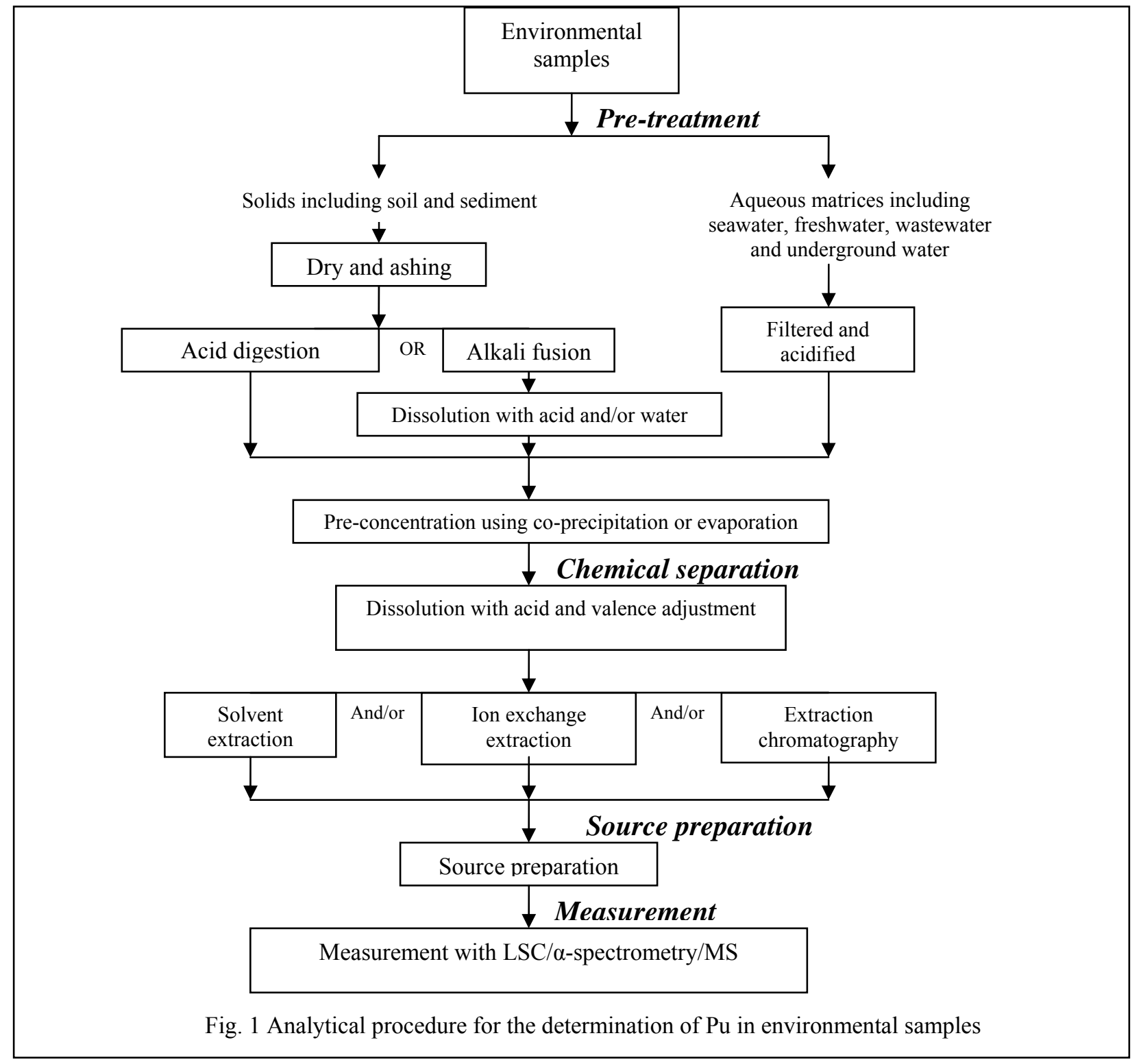




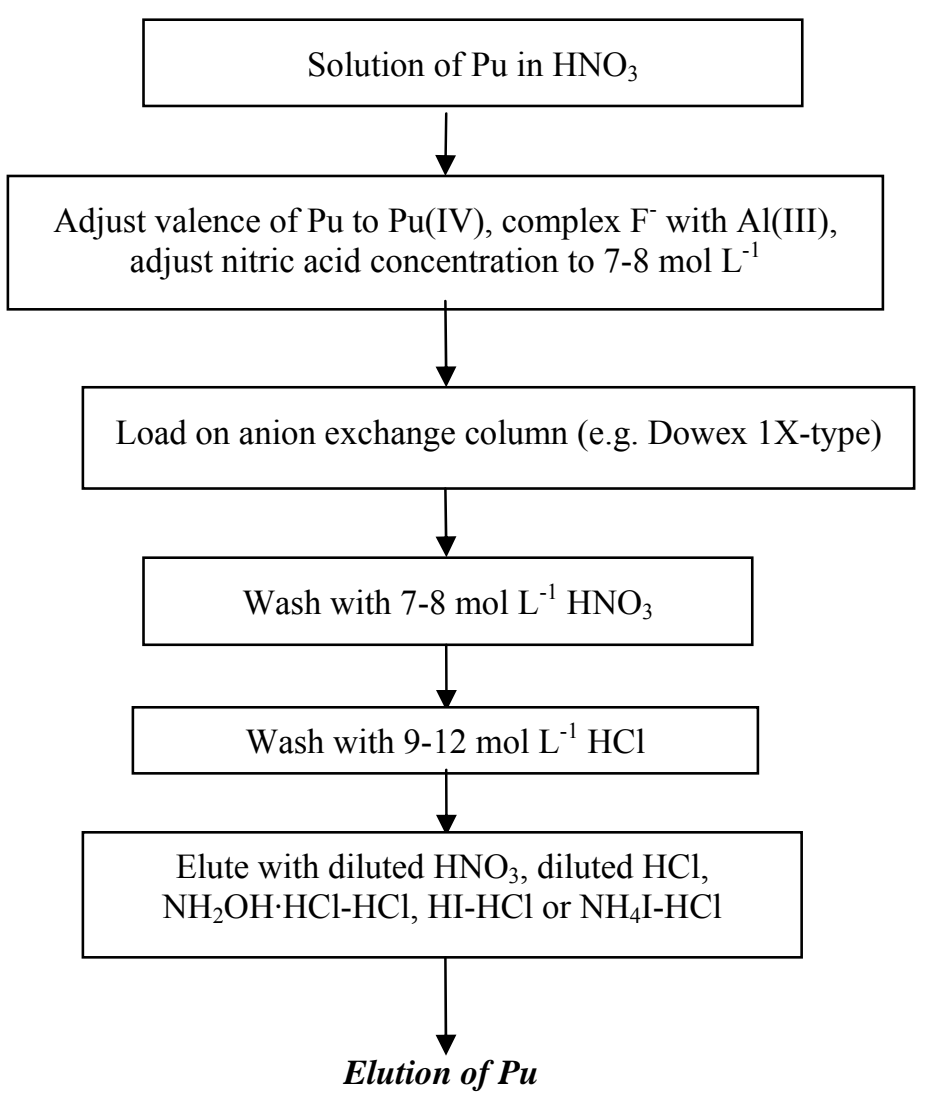

Fig. 2. General flow chart for separation of Pu using anion exchange extraction 

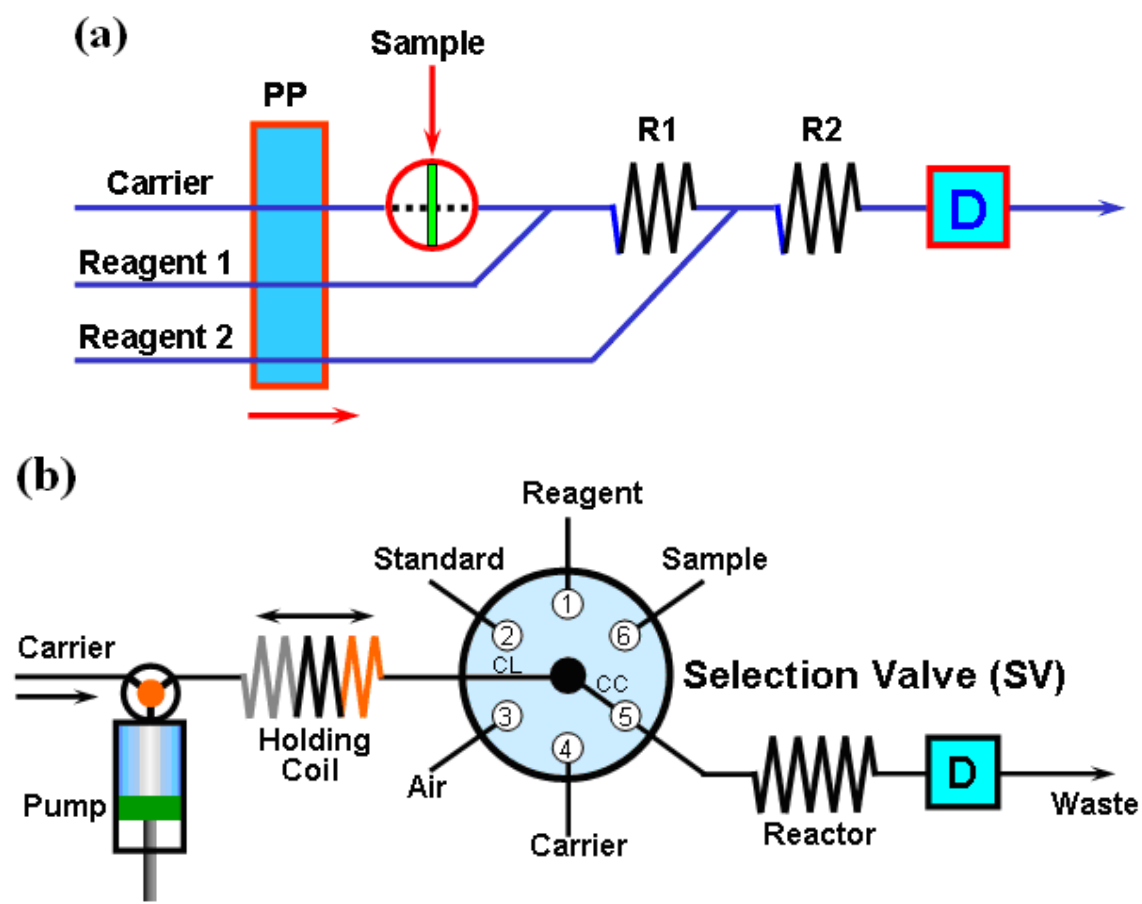

Fig. 3. Diagram of a three-line FI system (a) and an SI set-up furnished with a syringe pump (b)

$P P$ - peristaltic pump; $R 1$ - reaction coil 1; $R 2$ - reaction coil 2; $D$ - detector (Adapted from ref 40 with permission from Elsevier) 


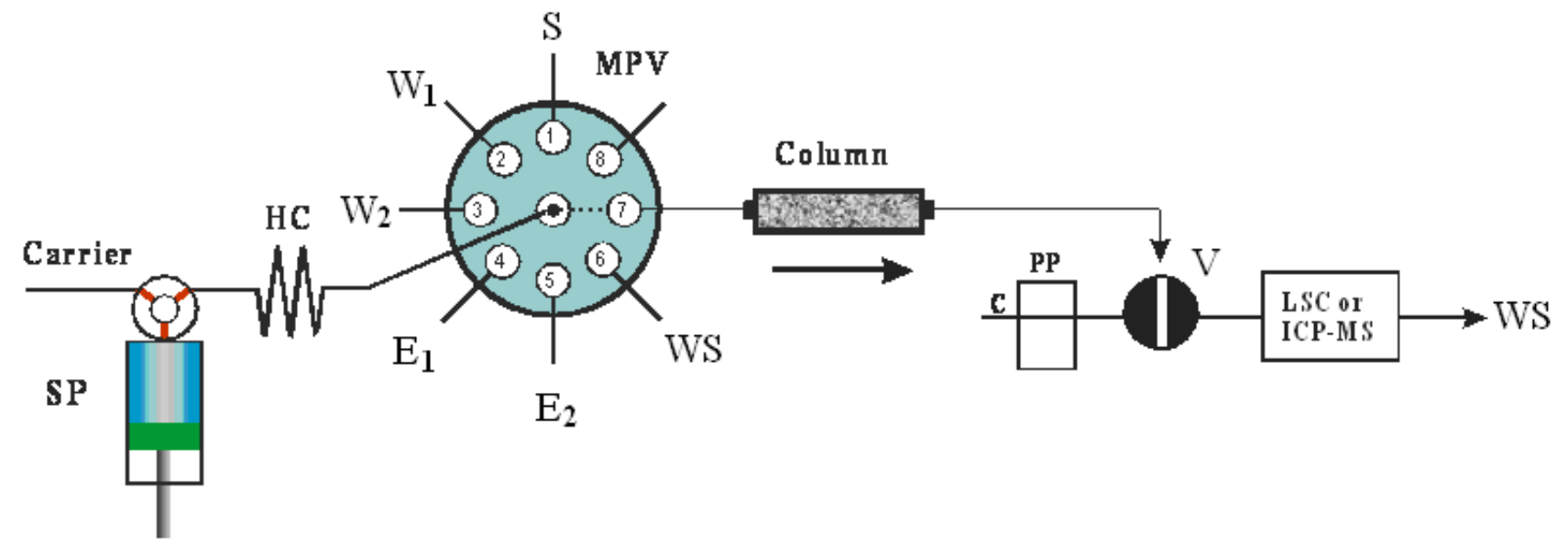

Fig 4. An SI manifold equipped with an extraction chromatographic column hyphenated to the analytical detection system via an ancillary FI system. $\mathrm{SP}$ - syringe pump; $\mathrm{HC}$ - holding coil 1; $\mathrm{S}$ - sample ; $\mathrm{E}_{1}, \mathrm{E}_{2}$ - eluent 1, eluent 2 ; W1,W2 -washing solution1, washing solution 2; WS - waste; MPV - multiport valve ; PP - peristaltic pump; C carrier; V - valve (Adapted from ref 42 with permission from Elsevier) 